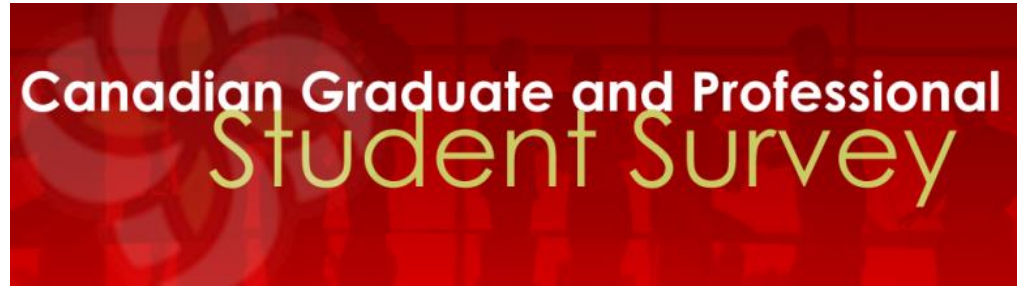

\title{
Comparison of Graduate Students with and without Disabilities using 2016 CGPSS Data
}

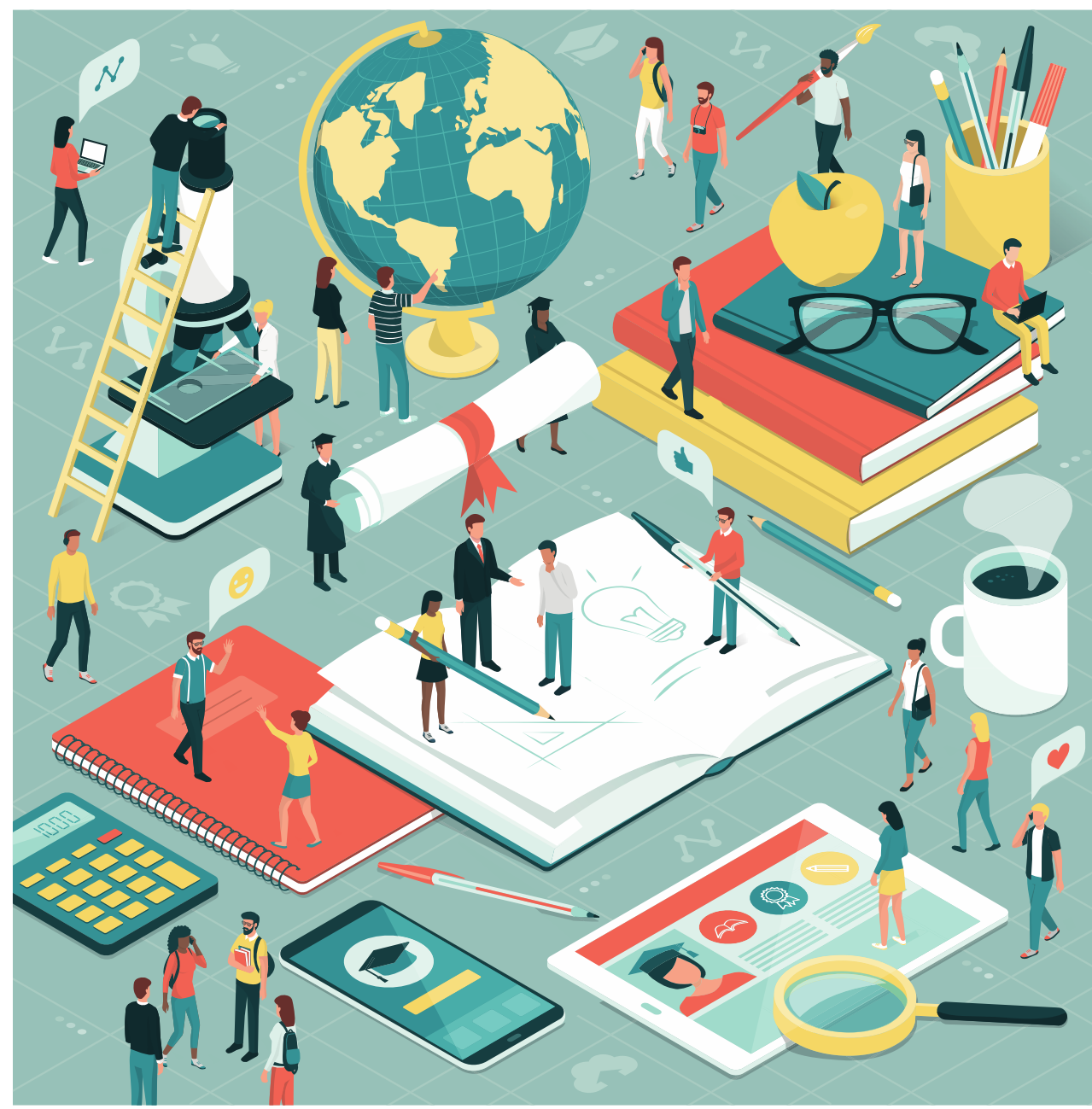

Prepared by:

Kathleen Clarke, Ph.D. Candidate Research Associate, NEADS

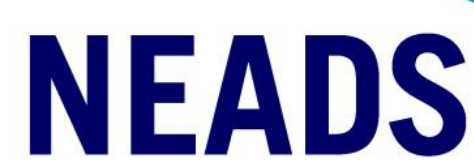

National Educational Association of Disabled Students

Association nationale des étudiant(e)s handicapé(e)s au niveau postsecondaire 
The National Educational Association of Disabled Students (NEADS) gratefully acknowledges funding support for this research from the Social Development Partnerships Program, Employment and Social Development Canada, the Ontario Human Capital Research and Innovation Fund and the Canadian Education and Research Institute for Counseling. 


\section{Table of Contents}

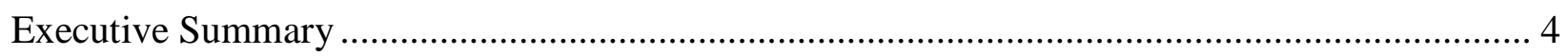

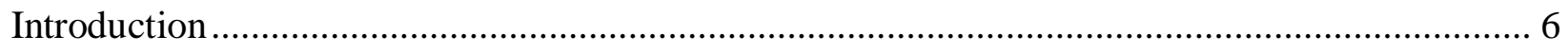

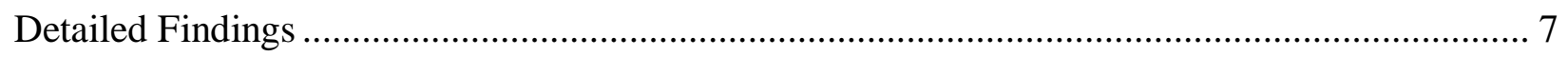

Tables and Graphs Displaying Data

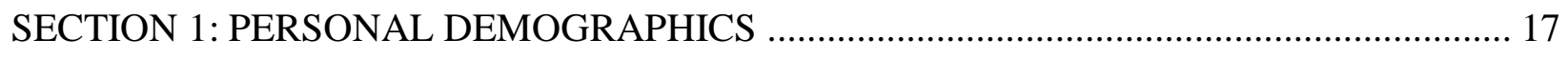

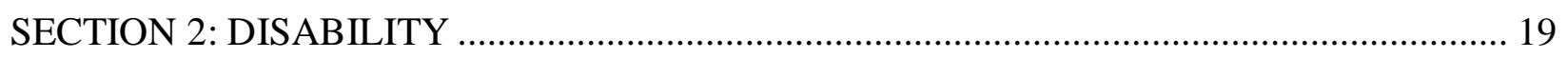

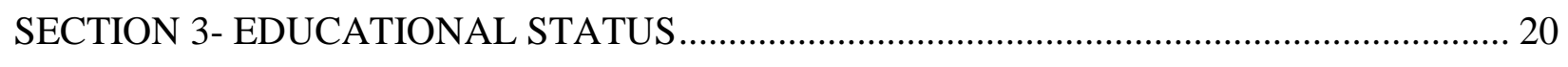

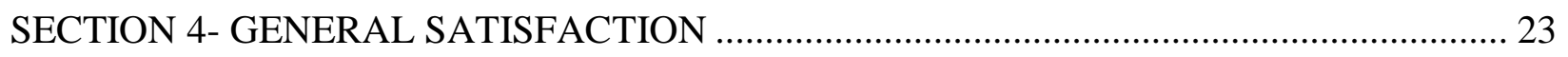

SECTION 5- SATISFACTION WITH PROGRAM, QUALITY OF INTERACTIONS, AND

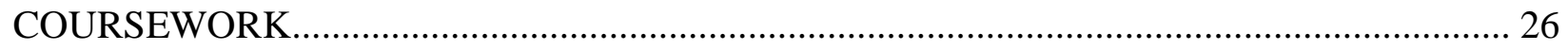

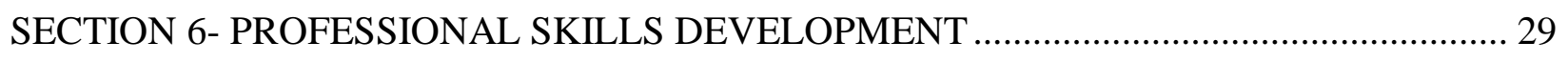

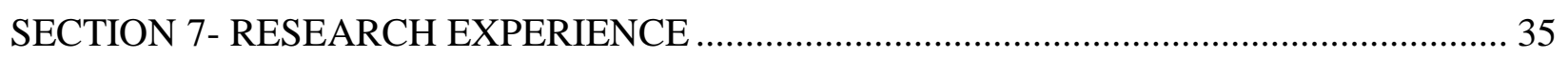

SECTION 8- PRESENTATIONS AND PUBLICATIONS ……………………...................... 38

SECTION 9- ADVISOR AND THESIS/DISSERTATION/RESEARCH PAPER ………........... 44

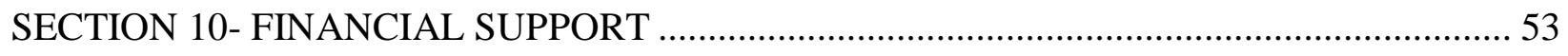

SECTION 11- UNIVERSITY RESOURCES AND STUDENT LIFE ……................................ 58

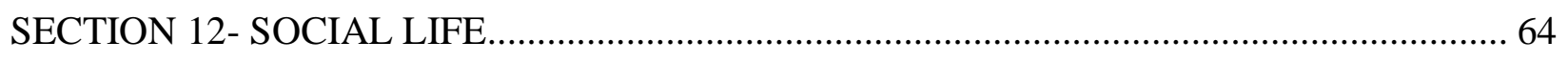

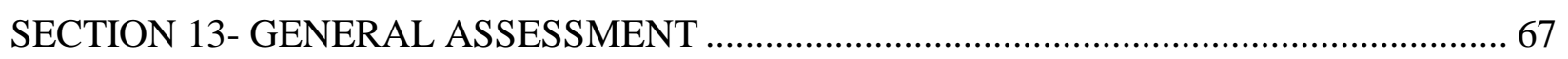




\section{Executive Summary}

$>$ This report focuses on a comparison of graduate students with and without disabilities and is part of a larger research initiative called "The Landscape of Accessibility and Accommodation for Students with Disabilities in Canadian Post-Secondary Education: 2016 - 2018."

$>$ The focus of this report is secondary analyses that was completed on all questions of the 2016 Canadian Graduate and Professional Student Survey (CGPSS).

$>$ Comparisons are made between graduate students without disabilities $(n=45,251)$ and with $(2,324)$ disabilities [SWD]

$>$ Several demographic differences were found on gender (more SWD were female), age (SWD were older), citizenship status (SWD more likely to be Canadian citizens), and Aboriginal status (more SWD identified in this way).

$>$ Most common type of disability was mental health (43\%); least common was Autism (3\%)

$>64 \%$ of respondents rated institutional efforts to accommodate them as excellent/very good/good

$>$ Only slight differences between the two groups in terms of type of program, degree level, year of study, program status, and academic load.

$>$ Most common reason for enrolling for both groups was 'to equip me to start a career, or advance an existing career outside of academia' ( $41 \%$ of students without and $36 \%$ of students with disabilities)

$>$ Select the same university: $71 \%$ of students without disabilities and $63 \%$ of student with disabilities said they would either 'Definitely' or 'Probably' select the same university. Students without disabilities more likely to recommend their program and university to others.

$>$ Students without disabilities were typically more satisfied with their program, the quality of interactions, and the coursework.

$>$ When asked to rate various types of professional development opportunities, students without disabilities typically rated them more favourably in comparison to students with disabilities

$>$ When asked to rate various items concerning research experience, students without disabilities consistently rated items more favourably

$>$ Participants were asked to indicate whether certain activities focused on presentations and publications occurred in their department, and then how often these activities took place.

- When identifying whether 'Seminars/colloquia at which students present their research,' a difference of $10 \%$ between the two groups was found. While $75 \%$ of students with disabilities indicated these events occurred only $65 \%$ of students without disabilities responded in the same way.

O When identifying whether they 'Co-authored in refereed journals with program faculty' and 'Published as sole or first author in a refereed journal' there were differences of $5 \%$ and $10 \%$ between the two groups.

- For co-authorship: $50 \%$ of students without and $40 \%$ of students with disabilities indicated they had co-authored with program faculty.

- For sole or first authorship: $47 \%$ of students without and $42 \%$ of students with disabilities indicated that they had done this.

In terms of rating their thesis advisor and the tasks that they completed, two key differences were found:

- 'Advisor encouraged discussion about current job market/career prospects: $30 \%$ of students without and $38 \%$ of students with disabilities indicated they either 'Disagreed' or 'Strongly Disagreed' with this item. These percentages were the highest for both groups across all 'disagree'/'strongly disagree' items, with other percentages not surpassing $22 \%$ of the samples. 
- Overall, students without disabilities meet with their advisor more often to discuss ongoing research/results and writing of dissertation.

- For sources of financial support, the greatest differences between the two groups were for 'loans, savings, or family assistance' (16\% difference), 'university-funded bursaries' (9\% difference), and provincial bursaries (6\% difference).

$>$ For amount of debt, graduate students with disabilities have a greater amount of debt at both the undergraduate and graduate levels.

- Undergraduate: $66 \%$ of students without disabilities and only $54 \%$ of students with disabilities reported they had no undergraduate student debt.

- Graduate: $49 \%$ of students without disabilities and only $36 \%$ of students with disabilities reported they had no graduate student debt.

$>$ When rating various university resources and student life events, students without disabilities typically rated services in a more positive light (based on responses of Excellent/Very Good/Good)

○ Differences between students with and without disabilities: Three of the examined services had a difference of over $10 \%$ between the two groups for responses of Excellent/Very Good/Good. These items included: Graduate student work/study space (56\% without and $46 \%$ with disabilities); research laboratories (42\% without and $29 \%$ with disabilities); and athletic facilities (53\% without and $42 \%$ with disabilities).

○ Disability/Access services: $40 \%$ of students with disabilities rated this service favourably, while 16\% rated it as 'Fair' or 'Poor'. Interestingly, 25\% of students with disabilities said they did not use this service, and $18 \%$ said it was not applicable to them.

Key differences between the groups on their perceived availability of social events:

○ Organized social activities within your advisor/research group: For the 'Never' response option, $45 \%$ of students with disabilities and $37 \%$ of those without said these activities did not occur; a difference of $8 \%$.

○ Organized social activities within your residence: For the 'Never' response option, $74 \%$ of students with disabilities and $65 \%$ of those without said these activities did not occur; a difference of $9 \%$.

Biggest obstacle to academic progress: The obstacle that was considered a 'major obstacle' by the highest number of respondents for both groups was 'work/financial commitments'. While $32 \%$ of students without disabilities responded that it was a major obstacle, this was much higher for students with disabilities, at $43 \%$ (a difference of $11 \%$ ). 


\section{Introduction}

\section{The Landscape of Accessibility and Accommodation Project}

The Landscape research project is an examination of the current landscape of accessibility, services, accommodations, technical equipment and supports for students with disabilities at publicly-funded post-secondary institutions across Canada.

The objectives of the overall 18-month project include:

1. an assessment of the landscape of academic accommodations;

2. an assessment of the landscape of co-curricular and experiential learning accommodations;

3. an assessment of the landscape of accessibility and accommodation practices in transitional spaces;

4. an assessment of the evolution toward the principles of accessibility and universal design;

5. an understanding of trends in accessibility and accommodation within Canadian postsecondary education;

6. identification of best practices and benchmarks; and

7. establishment of a national collaborative network.

One of the components of the research project involves secondary analyses of existing datasets. The research team examined various outlets such as professional organizations and Statistics Canada for datasets that focused on the post-secondary student population and which asked demographic questions concerning disabilities. The objective was to analyze these datasets and use these findings to supplement the primary data collection that was being done as part of the Landscape project. The research team was granted access to several datasets, one of which was the Canadian Graduate and Professional Student Survey, which is organized and run by the Canadian Association of Graduate Studies (CAGS).

\section{The Canadian Graduate and Professional Student Survey (CGPSS)}

Various institutions across Canada disseminated the CGPSS in 2007, 2010, 2013, and 2016. The purpose of the survey is to obtain information about graduate student satisfaction and the student experience. In Canada, it is the largest and most comprehensive source of data concerning these topics. More information about the CGPSS can be found on the website for CAGS (http://www.cags.ca/cgpss_home.php)

Institutional participation in the survey increased from 38 universities in 2010 to 50 in 2016 . As participation in data collection has grown, the survey instrument has also undergone several changes. Most relevant to the current analyses is that for the first time since its inception, the 2016 CGPSS survey included questions concerning disability. These inclusions mean that these data are now the biggest source of data about Canadian graduate students with disabilities. Analyses of these data allow for a more comprehensive understanding of this specific population of students.

\section{This Report}

This report shares analyses in which students with disabilities $(n=2,324)$ were compared to students without disabilities $(\mathrm{n}=45,251)$ in all sections of the CGPSS survey.

In this report, a description of the findings for each section is provided first. Following this, tables and figures presenting the data are then provided. 


\section{Findings}

\section{RESEARCH POPULATION}

- In response to "Do you identify as having a disability," 2,324 participants responded 'Yes'.

○ This 2,324 represents $5.14 \%$ of the total population of respondents $(\mathrm{N}=45,251)$

- 42,924 participants responded 'No' and 1,727 participants responded that they "Prefer not to Answer." These participants were excluded from the analyses.

\section{SECTION 1: PERSONAL DEMOGRAPHICS}

(Pages 14-15)

- Gender: More respondents with disabilities identified as female (67\%) in comparison to those without disabilities (58\%)

- Age: Students with disabilities were typically older. While $45 \%$ of respondents with disabilities identified as being 31 years old or older, only $37 \%$ of respondents without disabilities identified in the same way.

- Current Residence: Similar rates of students with and without disabilities live in offcampus housing not owned by the university ( $94 \%$ and $93 \%$ ).

- Marital Status: Similar rates of students with and without disabilities identify as being with a domestic partner (16\% of students without disabilities and $18 \%$ with disabilities). While $30 \%$ of those without disabilities identified as being married, $25 \%$ of students with disabilities identified in this way.

- Number of Children: Similar rates of students with and without disabilities responded they did not have any children or that this question was not applicable to them (78\% of those without and $80 \%$ of those with disabilities).

- Citizenship Status: Students with disabilities more likely to be Canadian citizens (90\%) in comparison to students without disabilities (69\%). Many more students without disabilities responded that they were citizens of another country with a student visa or other non-immigrant visa (25\%) in comparison to students with disabilities (8\%).

- Self-identification with Visible Minority Groups. More students with disabilities identified as being 'mixed origin' ( $8 \%$ versus $3 \%$ ). While $70 \%$ of students with disabilities did not identify with any of the listed minority groups, only $56 \%$ of those without disabilities did.

- Self-identification as Aboriginal (status or non-status Indian, Métis or Inuit). Eight percent $(\mathrm{n}=189)$ of students with disabilities self-identified as Aboriginal and 3\% $(\mathrm{n}=$ 1,265 ) of students without disabilities identified in the same way.

\section{SECTION 2: DISABILITY}

(Page 16)

- Type of Disability:

○ Most common was 'mental health': $43 \%(\mathrm{n}=991)$

- Second most common was 'learning disability': $30 \%(n=693)$

- Least common was 'Autism spectrum': $3.44 \%(n=80)$

- Institutional Efforts to Accommodate: Respondents rated institutional efforts favorably. While 64\% rated institutional efforts as Excellent, Very Good, or Good, 36\% rated as Fair or Poor. 


\section{SECTION 3- EDUCATIONAL STATUS}

(Pages 17-19)

- Type of Program: Most students in both samples were in a research-based program and already had a research director/advisor (62\% of students without and $63 \%$ of students with disabilities). Slightly more students with disabilities still did not have a research director/advisor (6\% versus 3\%).

- Degree Level: Similar rates of respondent from both groups were in master's $(65 \%$ without and $68 \%$ with disabilities) versus doctoral programs (35\% without and 32\% with disabilities), according to data provided by participating universities.

- With and Without Thesis: Slightly more students with disabilities (38\%) were in master's programs with a thesis component, in comparison to students without disabilities $(33 \%)$.

- Discipline:

- Most frequently reported disciplines for students with disabilities were 'Social Sciences' (20\%), 'Humanities' (14\%), 'Health science' (12\%), and 'Education' $(11 \%)$.

- Most frequently reported disciplines for students without disabilities were 'Engineering' (15\%), 'Health Science' (14\%), 'Social Sciences' (11\%), and 'Education' 10\%).

- Year of Study: Most students in both samples were in $1^{\text {st }}$ year (41\% in each group) and $28 \%$ of students without disabilities and $26 \%$ of students with disabilities were in $2^{\text {nd }}$ year. For students with disabilities, $12 \%$ were in $5^{\text {th }}$ year or above, and this value was $10 \%$ for students without disabilities.

- Program Status: Most students in both samples were still taking courses (54\% of those and $55 \%$ of those with disabilities). For both groups, $21 \%$ of the respondents had completed their coursew ork but had not yet passed their qualifying exams/paper.

- Reason for Enrolling: For both groups of students, the most common reason for enrolling in the current program was: 'to equip me to start a career, or advance an existing career outside of academia'; $41 \%$ of students without disabilities and $36 \%$ of students with disabilities recorded this response. The second most common response for both groups was: 'to equip me to start a career, or advance an existing career in academia'; $32 \%$ of respondents in both groups recorded this response option.

- Academic Load: Most students in both groups were enrolled full-time, with $82 \%$ of students without and $85 \%$ of students with disabilities indicating this.

- Expect to Graduate: Students without disabilities were slightly more likely to respond that they were expecting to graduate this year (39\%), in comparison to students with disabilities (34\%).

\section{SECTION 4- GENERAL SATISFACTION}

(Pages 20-22)

- Students without disabilities appear to be more likely to select the same university and field of study if they were to start their graduate careers over, in comparison to students with disabilities.

- Select same university: $71 \%$ of students without disabilities and $63 \%$ of student with disabilities said they would either 'Definitely' or 'Probably' select the same university. 
- Select same field of study: $81 \%$ of students without disabilities and $78 \%$ of students with disabilities said they would 'Definitely' or 'Probably' select the same field of study.

- Students without disabilities appear to be more likely to recommend their program and university to others.

○ Recommend program to others: $75 \%$ of students without disabilities and $66 \%$ of students with disabilities said they would 'Definitely' or 'Probably' recommend their university to someone considering their program.

- Recommend university to others: $63 \%$ of students without disabilities and 54\% of student with disabilities said they would 'Definitely' or 'Probably' recommend their university to someone in another field.

\section{SECTION 5- SATISFACTION WITH PROGRAM, QUALITY OF INTERACTIONS, AND COURSEWORK}

(Pages 23-25)

- Overall Pattern: Students without disabilities consistently rated all examined items more favourably (based on responses of 'Excellent', 'Very Good', 'Good') in comparison to students without disabilities. However, some items were rated more favourably than others.

- Rated Most Favourably: The two items that were rated the most favourably (based on responses of 'Excellent', 'Very Good', and 'Good') were 1) Intellectual quality of the faculty; and 2) Intellectual quality of fellow students.

- Similarity in responses: Responses for these items were generally similar for students with and without disabilities.

- Intellectual quality of faculty: Similar rates of students without and with disabilities indicated the intellectual quality of the faculty was 'Excellent', 'Very Good', or 'Good', with 96\% of those without and $95 \%$ of those with disabilities responding in this way.

- Intellectual quality of fellow students: Similar rates of students without and with disabilities indicated the intellectual quality of their peers was 'Excellent', 'Very Good', or 'Good', with $91 \%$ of those without and $90 \%$ of those with disabilities responding in this way.

- Rated Least Favourably: The two items that were rated the least favourably (based on responses of 'Fair' and 'Poor') were 1) Advice on the availability of financial support;

and 2) Opportunities to take coursework outside own department.

$\circ$ Difference in responses: Responses for these items were quite different, with a difference of $10 \%$ on the first item and $8 \%$ on the second.

- Advice on availability of financial support: While $36 \%$ of students without disabilities indicated advice about financial support was 'Fair' or 'Poor', many more students with disabilities (46\%) responded this way.

- Coursework outside of department: $30 \%$ of students without disabilities and $38 \%$ of students with disabilities indicated the opportunities to take coursework outside their department were 'Fair' or 'Poor'.

\section{SECTION 6- PROFESSIONAL SKILLS DEVELOPMENT}

(Pages 26-31) 
Graph One

- Overall Pattern: Students without disabilities consistently rated all examined items more favourably (based on responses of 'Excellent', 'Very Good', 'Good') in comparison to students without disabilities. However, some items were rated more favourably than others.

- Rated Most Favourably: For both groups, respondents rated the quality of support and training they received for 'Feedback on research' most favourably. $71 \%$ of students without and $65 \%$ of students with disabilities reported the feedback they received on their research was 'Excellent', 'Very Good', or 'Good.'

- Rated Least Favourably:

- For students without disabilities: The item rated least favourably was 'Advice/workshops on job searching,' where $26 \%$ of respondents indicated the support/training for this was 'Fair' or 'Poor'.

- For students with disabilities: The item rated least favourably was 'Advice/workshops on publishing your work,' where 34\% of respondents indicated the support/training on this was 'Fair' or 'Poor.'

- 'Did not participate' Response Option: Approximately 25\% of respondents in both groups indicated they did not participate in four of the examined support/training opportunities including: 1) Advice/workshops on standards for academic writing in your field; 2) Advice/workshops on standards for writing grant proposals; 3)

Advice/workshops on publishing your work; and 4) Advice/workshops on job searching.

Graph Two

- Overall Pattern: Students without disabilities consistently rated all examined items more favourably (based on responses of 'Excellent', 'Very Good', 'Good') in comparison to students without disabilities.

- Rated Most Favourably: For students with and without disabilities, the item rated most favourably was 'Advice/workshops about research ethics in human subject research. Similar rates of students from both groups indicated this was 'Excellent', 'Very Good', or 'Good', with $41 \%$ of students without and $40 \%$ of students with disabilities responding in this way.

- Rated Least Favourably: For most of the items, percentages of respondents indicating the advice/workshops were 'Fair' were similar across students with and without disabilities. However, when looking at the percentages for 'Poor,' some large differences are found.

○ Advice/workshops about research positions: While $27 \%$ of respondents with disabilities rated this as 'Poor', only $16 \%$ of respondents without disabilities responded this way, which is a difference of $11 \%$.

○ Advice/workshops on career options outside of academia: While $27 \%$ of respondents with disabilities rated this as 'Poor', only $17 \%$ of respondents without disabilities responded this way, which is a difference of $10 \%$.

- 'Did not participate' Response Option: For all items, students without disabilities had higher percentages for this response options, indicating that students with disabilities do participate in these types of workshops.

- 'Not applicable' Response Option: For the most part, percentages were similar across students with and without disabilities. 
○ The greatest difference between the two groups was $12 \%$, for 'Advice/workshops about research ethics in the use of animals.' For this item, 53\% of students with disabilities responded that it was not applicable, while only $41 \%$ of students without disabilities responded in the same way.

Graph Three

- Similar Favourable Responses (Excellent/Very Good/Good): For four out of six items in this section, percentages of students across the two groups are considered similar, with a difference of $3 \%$ or less. The items with similar favourable ratings include:

'Advice/workshops on career options'; 'Advice/workshops on job preparation and professional practice'; 'Advice/workshops on professional ethics'; and 'Opportunities for contact with practicing professionals'

- Rated Most Favourably: For students with and without disabilities, 'Opportunities for contact with practicing professionals' was rated the most favourably with $67 \%$ of students without and $68 \%$ of students with disabilities responding with either 'Excellent', 'Very Good', or 'Good'.

- Rated Least Favourably: For students with and without disabilities, 'Advice/workshops on career options' was rated the least favourably with $25 \%$ of students without and $31 \%$ of students with disabilities responding with 'Fair' or 'Poor'.

○ Greatest difference: between the two groups when looking at the 'Fair' and 'Poor' response options was for the item 'Advice/workshops on the standards for writing in your profession,' where $16 \%$ of students without and $24 \%$ of students with disabilities responded in this way (a difference of $8 \%$ ).

- 'Did not participate' and 'Not applicable': Percentages of respondents for both of these respondents were quite similar, with differences of $3 \%$ or less between the two groups.

\section{SECTION 7- RESEARCH EXPERIENCE}

(Pages 32-34)

- Overall Pattern: Students without disabilities consistently rated all items more favourably (based on responses of 'Excellent', 'Very Good', and 'Good') in comparison to students without disabilities.

- Rated Most Favourably: Items rated most favourably by both samples were: 1) Conducting independent research since starting your graduate program; and 2) Faculty guidance in formulating a research topic.

$\circ$ Conducting independent research: $64 \%$ of students without and $57 \%$ of students with disabilities responded that the quality/availability of support for conducting independent research was 'Excellent', 'Very Good', or 'Good'.

$\circ$ Faculty guidance in formulating a research topic: $63 \%$ of students without and $57 \%$ of students with disabilities responded that the quality/availability of faculty support for formulating a research topic was 'Excellent', 'Very Good', or 'Good'.

- Rated Least Favourably: The item rated least favourably by students with disabilities was 'Training in research methods before beginning your own research.'

$\circ$ Training in research methods: $25 \%$ of students without and $33 \%$ of students with disabilities responded that their training in research methods (before beginning research) was 'Fair' or 'Poor'. 
- Collaboration with faculty in writing a grant proposal. For students with and without disabilities, the rates of respondents for both 'Did not participate' and 'Not applicable' were highest for this question.

- For 'Did not participate': 25\% of students without and 22\% of students with disabilities responded in this way. This is much higher than the $5-11 \%$ of those who responded, 'Did not participate' on the other questions in this section.

- For 'Not applicable': $18 \%$ of students without and $21 \%$ of students with disabilities responded in this way.

\section{SECTION 8- PRESENTATIONS AND PUBLICATIONS}

(Pages 35-40)

\section{- Occurrence - Similarities:}

○ When identifying whether items occurred in their department, similar percentages of respondents indicated 'departmental funding for students to attend national/regional meetings' and 'attend national scholarly meetings.' For students with and without disabilities, approximately $50 \%$ of respondents from both groups responses that these two items occurred.

- When identifying whether 'Deliver any papers or present a poster at national scholarly meetings' occurred in their department, similar rates of students from each group indicated that they did. $67 \%$ of students without disabilities and $66 \%$ of students with disabilities responded that these opportunities did occur.

- Occurrence - Differences:

○ When identifying whether 'Seminars/colloquia at which students present their research,' a difference of $10 \%$ between the two groups was found. While $75 \%$ of students with disabilities indicated these events occurred only $65 \%$ of students without disabilities responded in the same way.

- When identifying whether they 'Co-authored in refereed journals with program faculty' and 'Published as sole or first author in a refereed journal' there were differences of $5 \%$ and $10 \%$ between the two groups.

- For co-authorship: $50 \%$ of students without and $40 \%$ of students with disabilities indicated they had co-authored with program faculty.

- For sole or first authorship: $47 \%$ of students without and $42 \%$ of students with disabilities indicated that they had done this.

\section{SECTION 9- ADVISOR AND THESIS/DISSERTATION/RESEARCH PAPER (Pages 41-49)}

- Level of Agreement with Advisor Behaviours: The overall pattern is that in general, more students without disabilities typically responded with 'Strongly Agree' or 'Agree' in comparison to students with disabilities.

- Differences between two groups on 'Strongly Agree'/ 'Agree': Differences ranged from 3\% (advisor gave constructive feedback on work; advisor returned work promptly; advisor was available for regular meetings) to $8 \%$ (advisor promoted my professional development; advisor encouraged discussions about job markets and career prospects

- Advisor encouraged discussion about current job market/career prospects: $30 \%$ of students without and $38 \%$ of students with disabilities indicated they either 'Disagreed' or 'Strongly Disagreed' with this item. These percentages were 
the highest for both groups across all 'disagree'/'strongly disagree' items, with other percentages not surpassing $22 \%$ of the samples.

○ Most-to-least agreed upon statements for students with disabilities:

- $75 \%$ or more respondents indicated that 'agreed'/'strongly agreed' for all items except 'my advisor encouraged discussions about current job market and career prospects,' where only $62 \%$ responded in the same way.

- The top two most agreed upon statements were 'my advisor gave me constructive feedback on my work' (90\% said 'agree' or 'strongly agree') and 'my advisor served as my advocate when necessary' (88\% said 'agree' or 'strongly agree')

- Meeting and Communicating with Advisor: Overall, students without disabilities meet with their advisor more often to discuss ongoing research/results and writing of dissertation. Also, students from both groups do not meet with their advisor to discuss dissertation writing as often as they meet to discuss ongoing research and results.

$\circ$ Ongoing research results: There was a difference of $10 \%$ for meeting 'Four or more times per month' with $36 \%$ of students without and $26 \%$ of students with disabilities responding in this way. While $19 \%$ of students without disabilities said they meet their advisor less than once a month, this was much higher for students with disabilities, where $27 \%$ indicated they met less than once per month.

$\circ$ Writing of the dissertation draft: There was a difference of $7 \%$ for meeting 'Four or more times per month' with $20 \%$ of students without and $1 \%$ of students with disabilities meeting this often. While $36 \%$ of students without disabilities indicated they met less than once a month to discuss dissertation writing, this value was $41 \%$ for students with disabilities.

\section{- Advisory Committee:}

- Existence of Committee: Similar rates of students from both groups indicated they had an advisory committee, with $32 \%$ of students without and $34 \%$ of students with disabilities responding this way.

- Committee expectations: Of those with an advisory committee, students with and without disabilities appear to have similar perspectives on what they feel their committee expects from them, in terms of receiving a written progress report and meeting at least once.

- Presence of interaction: Of those with a committee, $74 \%$ of participants from each group responded that they had interacted with their advisory committee at least once.

- Format of interaction: Of those who had at least one interaction, for most participants this interaction took place in a formal meeting ( $87 \%$ of students without and $82 \%$ of students with disabilities responded this way).

- Rating of Feedback: Of those who had an interaction, approximately $90 \%$ from each group of respondents indicated they 'agreed' or 'strongly agreed' that the committee feedback was useful. 


\section{SECTION 10- FINANCIAL SUPPORT}

(Pages 50-54)

- Sources of Financial Support:

○ Top 5 sources for students with disabilities: loans, savings, or family assistance (55\%), graduate teaching assistantships (42\%), graduate research assistantship (30\%), university-funded bursary (30\%), and off campus employment (25\%).

○ Top 10 sources for students with disabilities: When examining the top sources of financial support for students with disabilities and comparing the percentage of respondents from each group that reported using that source of support, it is clear that students with disabilities are more reliant on these sources than those without disabilities (some sources to a greater than others, however).

- Differences between students with and without disabilities:

- For 14 out of 18 items there was a difference of only $3 \%$ between the two groups.

- The greatest differences between the two groups were for 'loans, savings, or family assistance' (16\% difference), 'university-funded bursaries' (9\% difference), and provincial bursaries (6\% difference).

- Loans, savings, or family assistance: While 55\% of students with disabilities reported using this source of financial support, only $39 \%$ of students without disabilities reported using this.

\section{- Amount of Education Debt:}

○ Overall, graduate students with disabilities have a greater amount of debt at both the undergraduate and graduate levels.

○ Undergraduate: $66 \%$ of students without disabilities and only $54 \%$ of students with disabilities reported they had no undergraduate student debt.

- Graduate: $49 \%$ of students without disabilities and only $36 \%$ of students with disabilities reported they had no graduate student debt.

\section{SECTION 11- UNIVERSITY RESOURCES AND STUDENT LIFE}

(Pages 55-60)

\section{- Rating Quality of Services:}

○ Overall Pattern: When asked to rate the quality of various resources, the overall pattern shows students without disabilities typically rate services in a more positive light (based on responses of Excellent/Very Good/Good), with some exceptions such as with health care services and student counselling.

- Services that few students reported using: Child care services; services to international students attending this university; services to students attending this university but studying abroad; ombudsperson's office.

- Differences between students with and without disabilities: Three of the examined services had a difference of over $10 \%$ between the two groups for responses of Excellent/Very Good/Good. These items included: Graduate student work/study space (56\% without and $46 \%$ with disabilities); research laboratories (42\% without and 29\% with disabilities); and athletic facilities (53\% without and $42 \%$ with disabilities).

○ Disability/Access services: $40 \%$ of students with disabilities rated this service favourably, while $16 \%$ rated it as 'Fair' or 'Poor'. Interestingly, $25 \%$ of students 
with disabilities said they did not use this service, and $18 \%$ said it was not applicable to them.

- For 'Did not participate': For 9 out of 20 items, there was a difference of 5\% or more on this response option. These items included: library facilities; research laboratories; health care services; child care services; financial aid office; athletic facilities; housing assistance; bookstore; student government office. For some items, the percentage of students without disabilities was higher, and for others it was lower.

- Location of Offices:

○ Overall Patterns:

- For most services, the most common location where students use the service was the Central Office. The two items that were exceptions to this were "Graduate student work/study space' and 'research laboratories' where higher percentages of students with and without disabilities indicated they used the Local Office for these services.

- It appears that more students with disabilities use the Central Office for most of the examined services, in comparison to students without disabilities (with the exception of graduate student work/study space). Conversely, the percentages of students without disabilities indicating they used the Local Office for services was typically higher in comparison to students with disabilities (with the exception of graduate student work/study space).

\section{SECTION 12- SOCIAL LIFE}

(Pages 61-63)

\section{- Availability Social Events:}

- No differences: For two of the four examined items, student perceptions of the availability of activities are quite similar (organized university-wide social activities; organized social activities within your department).

- Organized social activities within your advisor/research group: For the 'Never' response option, $45 \%$ of students with disabilities and $37 \%$ of those without said these activities did not occur; a difference of $8 \%$.

$\circ$ Organized social activities within your residence: For the 'Never' response option, $74 \%$ of students with disabilities and $65 \%$ of those without said these activities did not occur; a difference of $9 \%$.

- Attending Social Events:

○ Small differences: For two of the four examined items, participation in 'organized social activities within department' and 'organized social activities within your advisor/research group' appears to be similar.

O Organized university-wide social activities: The greatest difference for this item is on the 'Frequently' response option, where $61 \%$ of students with disabilities and $52 \%$ of those without said they attended these activities frequently.

- Organized social activities within our residence: For the 'Frequently' response option, more students with disabilities $(54 \%)$ indicated they attended frequently in comparison to the $44 \%$ of students without disabilities. More students without 
disabilities (40\%) indicated they attended occasionally, in comparison to students with disabilities.

\section{SECTION 13- GENERAL ASSESSMENT}

(Pages 64-68)

- Quality Rating:

- Overall Pattern: Students without disabilities rated all examined items more favourably than students with disabilities.

- Highest Rating: For both groups of respondents, the item that was rated most favourably was 'your academic experience at this university'. $90 \%$ of students without and $83 \%$ of students with disabilities rated this item as Excellent/Very Good/Good.

- Lowest Rating: 'Your student life experience at this university' was rated the least favourably by both groups. For students without disabilities, $79 \%$ responded with Excellent/Very Good/Good while 21\% responded with Fair/Poor. For students with disabilities, 68\% responded with Excellent/Very Good/Good and $32 \%$ responded with Fair/Poor.

- $\quad$ Obstacles to Academic Progress:

- Biggest Obstacle: The obstacle that was considered a 'major obstacle' by the highest number of respondents for both groups was 'work/financial commitments'. While $32 \%$ of students without disabilities responded that it was a major obstacle, this was much higher for students with disabilities, at $43 \%$ (a difference of $11 \%$ ).

- Not an Obstacle: For six out of seven examined factors, more students without disabilities indicated they were 'not an obstacle', in comparison to students with disabilities. The only item where more students with disabilities indicated it was not an obstacle was for 'immigration laws or regulations.'

- Importance of Various Opportunities:

○ Most important: 'Networking with local/provincial/federal government' appeared to be the most important item for both groups, with $43 \%$ of students without and $44 \%$ of students with disabilities indicating this was 'very important.'

- Least important: 'Study abroad' was the least important item for both groups, with $35 \%$ of students without and $41 \%$ of students with disabilities responding that this was 'Not important.' 


\section{SECTION 1: PERSONAL DEMOGRAPHICS}

\section{Table 1}

Participant Profiles

\begin{tabular}{|c|c|c|c|c|}
\hline & \multicolumn{2}{|c|}{$\begin{array}{l}\text { Students without } \\
\text { Disabilities }\end{array}$} & \multicolumn{2}{|c|}{$\begin{array}{l}\text { Students with } \\
\text { Disabilities }\end{array}$} \\
\hline & $n$ & $\%$ & $n$ & $\%$ \\
\hline \multicolumn{5}{|l|}{ Gender-University Data } \\
\hline Male & 17,870 & 41.63 & 766 & 32.93 \\
\hline Female & 25,051 & 58.37 & 1,560 & 67.07 \\
\hline \multicolumn{5}{|l|}{ Age } \\
\hline 20 or younger & 14 & 0.03 & 0 & 0.00 \\
\hline $21-25$ & 13,345 & 31.17 & 610 & 26.30 \\
\hline $26-30$ & 13,783 & 32.19 & 675 & 29.11 \\
\hline $31-35$ & 6,892 & 16.10 & 416 & 17.94 \\
\hline $36-40$ & 3,524 & 8.23 & 210 & 9.06 \\
\hline $41-45$ & 2,232 & 5.21 & 130 & 5.61 \\
\hline Over 45 & 3,021 & 7.06 & 278 & 11.99 \\
\hline \multicolumn{5}{|l|}{ Current Residence } \\
\hline $\begin{array}{l}\text { On-campus student housing (no resident } \\
\text { assistant/dorm responsibilities) }\end{array}$ & 1,475 & 3.45 & 78 & 3.36 \\
\hline $\begin{array}{l}\text { On-campus student housing (with resident } \\
\text { assistant/dorm responsibilities) }\end{array}$ & 658 & 1.54 & 21 & 0.91 \\
\hline $\begin{array}{l}\text { Off-campus housing owned by this } \\
\text { university }\end{array}$ & 608 & 1.42 & 31 & 1.34 \\
\hline $\begin{array}{l}\text { Off-campus housing not owned by this } \\
\text { university }\end{array}$ & 39,991 & 93.59 & 2,189 & 94.39 \\
\hline \multicolumn{5}{|l|}{ Marital Status } \\
\hline Not married & 22,155 & 51.79 & 1,169 & 50.47 \\
\hline Married & 12,689 & 29.66 & 581 & 25.09 \\
\hline Divorced & 719 & 1.68 & 78 & 3.37 \\
\hline Separated & 429 & 1.00 & 58 & 2.50 \\
\hline Widowed & 68 & 0.16 & 7 & 0.30 \\
\hline With domestic partner & 6,717 & 15.70 & 423 & 18.26 \\
\hline \multicolumn{5}{|l|}{ Number of Children } \\
\hline None/Not applicable & 33,229 & 77.63 & 1,851 & 79.78 \\
\hline 1 child & 3,544 & 8.28 & 159 & 6.85 \\
\hline
\end{tabular}




\begin{tabular}{|c|c|c|c|c|}
\hline & \multicolumn{2}{|c|}{$\begin{array}{l}\text { Students without } \\
\text { Disabilities }\end{array}$} & \multicolumn{2}{|c|}{$\begin{array}{l}\text { Students with } \\
\text { Disabilities }\end{array}$} \\
\hline & $n$ & $\%$ & $n$ & $\%$ \\
\hline 2 children & 3,949 & 9.23 & 187 & 8.06 \\
\hline 3 children & 1,482 & 3.46 & 77 & 3.32 \\
\hline 4 or more children & 601 & 1.40 & 46 & 1.98 \\
\hline \multicolumn{5}{|l|}{ Current Citizenship Status } \\
\hline Canadian Citizen & 29,428 & 68.66 & 2,085 & 89.72 \\
\hline Canadian Permanent Resident & 2,820 & 6.58 & 60 & 2.58 \\
\hline $\begin{array}{l}\text { Citizen of another country with a student } \\
\text { visa or other non-immigrant visa }\end{array}$ & 10,613 & 24.76 & 179 & 7.70 \\
\hline \multicolumn{5}{|l|}{$\begin{array}{l}\text { Identifies with visible minority group(s) } \\
\text { Responses of 'Yes' }\end{array}$} \\
\hline $\begin{array}{l}\text { Black (e.g. African, African American, } \\
\text { African Canadian, Caribbean) }\end{array}$ & 2,512 & 5.85 & 94 & 4.04 \\
\hline $\begin{array}{l}\text { East Asian (e.g. Chinese, Japanese, } \\
\text { Korean, Polynesian) }\end{array}$ & 4,679 & 10.90 & 104 & 4.47 \\
\hline $\begin{array}{l}\text { South Asian (e.g. Indian, Pakistani, Sri } \\
\text { Lankan, Bangladeshi) }\end{array}$ & 3,532 & 8.23 & 81 & 3.48 \\
\hline $\begin{array}{l}\text { Southeast Asian (e.g. Burmese, } \\
\text { Cambodian, Filipino, Laotian, Malaysian, } \\
\text { Thai, Vietnamese) }\end{array}$ & 652 & 1.52 & 24 & 1.03 \\
\hline $\begin{array}{l}\text { West Asian (e.g. Arabian, Armenian, } \\
\text { Iranian, Israeli, Lebanese, Palestinian, } \\
\text { Syrian, Turkish) }\end{array}$ & 2,910 & 6.78 & 73 & 3.14 \\
\hline $\begin{array}{l}\text { Latin American (e.g. Mexican, Indigenous } \\
\text { Central and South American) }\end{array}$ & 1,478 & 3.44 & 59 & 2.54 \\
\hline Mixed origin, please specify & 1,473 & 3.43 & 178 & 7.65 \\
\hline None & 24,016 & 55.95 & 1,618 & 69.53 \\
\hline \multicolumn{5}{|l|}{$\begin{array}{l}\text { Do you self-identify with, or have ancestry as } \\
\text { an Aboriginal person (status or non-status } \\
\text { Indian, Métis or Inuit)? }\end{array}$} \\
\hline Yes & 1,265 & 2.96 & 189 & 8.16 \\
\hline No & 41,477 & 97.04 & 2,126 & 91.84 \\
\hline
\end{tabular}




\section{SECTION 2: DISABILITY}

Table 2

Participants' Responses: Do you self-identify with any disability or impairment?

\begin{tabular}{lcc}
\hline & $n$ & $\%$ \\
\hline Yes & 2,327 & 4.95 \\
No & 42,924 & 91.37 \\
Prefer not to respond & 1,727 & 3.68 \\
\hline
\end{tabular}

Note. $\mathrm{N}=46,978$

Table 3

Types of Disabilities

\begin{tabular}{lcc}
\hline & $n$ & $\%$ \\
\hline Sensory (vision or hearing) & 308 & 13.25 \\
Mobility & 255 & 10.97 \\
Learning (e.g. ADHD, Dyslexia) & 693 & 29.82 \\
Mental Health (e.g. Depression, Bipolar) & 991 & 42.64 \\
Autism Spectrum (e.g. Autism, Asperger's) & 80 & 3.44 \\
Chronic (e.g. Chron's, Colitis, MS) & 397 & 17.08 \\
A disability or impairment not listed above & 334 & 14.5 \\
Prefer not to respond & 138 & 6.0
\end{tabular}

Note. Participants could select all that apply

$\mathrm{N}=2,324$

Table 4

Participants' Responses: How would you rate your institution's efforts to accommodate your disability or impairment in your graduate program?

\begin{tabular}{lcc}
\hline & $n$ & $\%$ \\
Excellent & 398 & 18.28 \\
Very good & 457 & 20.99 \\
Good & 548 & 25.17 \\
Fair & 457 & 19.94 \\
Poor & 398 & 15.62 \\
\hline
\end{tabular}

Note. $N=2,177$. 


\section{SECTION 3- EDUCATIONAL STATUS}

\section{Table 5}

Participants' Responses: Is your program research-based, under the supervision of a research director/advisor, or is more course-based without the same level of supervision?

\begin{tabular}{lcccc}
\hline & \multicolumn{2}{c}{$\begin{array}{c}\text { Students without } \\
\text { Disabilities }\end{array}$} & \multicolumn{2}{c}{$\begin{array}{c}\text { Students with } \\
\text { Disabilities }\end{array}$} \\
\cline { 2 - 5 } & $n$ & $\%$ & $n$ & $\%$ \\
\hline $\begin{array}{l}\text { Student Response } \\
\quad \text { Mostly research-based, and I already have } \\
\text { a research director/advisor }\end{array}$ & 26,772 & 62.37 & 1,460 & 62.74 \\
$\quad \begin{array}{l}\text { Mostly research-based, but I still do not } \\
\text { have a research director/advisor }\end{array}$ & 1,173 & 2.73 & 128 & 5.50 \\
$\quad$ & 14,979 & 34.90 & 739 & 31.76 \\
\hline
\end{tabular}




\begin{tabular}{|c|c|c|c|c|}
\hline & \multicolumn{2}{|c|}{$\begin{array}{l}\text { Students without } \\
\text { Disabilities }\end{array}$} & \multicolumn{2}{|c|}{$\begin{array}{l}\text { Students with } \\
\text { Disabilities }\end{array}$} \\
\hline & $n$ & $\%$ & $n$ & $\%$ \\
\hline \multicolumn{5}{|l|}{ Degree Level- University Data } \\
\hline Master's & 28,067 & 65.43 & 1,573 & 67.63 \\
\hline Doctoral & 14,826 & 34.57 & 753 & 32.37 \\
\hline \multicolumn{5}{|l|}{$\begin{array}{l}\text { Program/Degree Level (calculated using } \\
\text { combined data) }\end{array}$} \\
\hline Master's - without thesis & 14,026 & 32.68 & 680 & 29.22 \\
\hline Master's- with thesis & 14,072 & 32.78 & 894 & 38.42 \\
\hline Doctoral & 14,826 & 34.54 & 753 & 32.36 \\
\hline \multicolumn{5}{|l|}{ Discipline } \\
\hline $\begin{array}{l}\text { Architecture/Landscape/Urban } \\
\text { Design/Planning }\end{array}$ & 383 & 0.90 & 18 & 0.78 \\
\hline Arts and Culture & 343 & 0.80 & 31 & 1.34 \\
\hline Biological Science & 3,136 & 7.33 & 125 & 5.39 \\
\hline Business/Management & 3,651 & 8.54 & 86 & 3.71 \\
\hline Education & 4,069 & 9.52 & 248 & 10.69 \\
\hline Engineering & 6,551 & 15.32 & 127 & 5.47 \\
\hline Environmental Science & 1,726 & 4.04 & 67 & 2.89 \\
\hline Finance/Mathematics/Computing & 410 & 0.96 & 8 & 0.34 \\
\hline Fine and Applied Arts & 1,069 & 2.50 & 68 & 2.93 \\
\hline Health Science & 6,080 & 14.22 & 272 & 11.72 \\
\hline Humanities & 3,469 & 8.11 & 343 & 14.78 \\
\hline Journalism & 36 & 0.08 & 8 & 0.34 \\
\hline Law & 250 & 0.58 & 10 & 0.43 \\
\hline Library and Information Sciences & 423 & 0.99 & 56 & 2.41 \\
\hline Other & 2,445 & 5.72 & 157 & 6.77 \\
\hline Physical and Mathematical Sciences & 2,474 & 5.79 & 103 & 4.44 \\
\hline Public Administration/Public & 789 & 1.85 & 39 & 1.68 \\
\hline \multicolumn{5}{|l|}{ Policy/International Relations } \\
\hline Social Sciences & 4,863 & 11.37 & 467 & 20.13 \\
\hline Social Work & 594 & 1.39 & 87 & 3.75 \\
\hline \multicolumn{5}{|l|}{ Year of Study- University Data } \\
\hline $1^{\text {st }}$ year & 17,292 & 41.00 & 931 & 40.73 \\
\hline $2^{\text {nd }}$ year & 11,965 & 28.37 & 601 & 26.29 \\
\hline $3^{\text {rd }}$ year & 5,599 & 13.28 & 310 & 13.56 \\
\hline $4^{\text {th }}$ year & 3,137 & 7.44 & 179 & 7.83 \\
\hline $5^{\text {th }}$ year & 2,069 & 4.91 & 112 & 4.90 \\
\hline $6^{\text {th }}$ year or above & 2,112 & 5.01 & 153 & 6.69 \\
\hline \multicolumn{5}{|l|}{ Current Program Status } \\
\hline I am still taking courses (All streams) & 23,200 & 54.10 & 1,286 & 55.34 \\
\hline
\end{tabular}




\begin{tabular}{|c|c|c|c|c|}
\hline & \multicolumn{2}{|c|}{$\begin{array}{l}\text { Students without } \\
\text { Disabilities }\end{array}$} & \multicolumn{2}{|c|}{$\begin{array}{l}\text { Students with } \\
\text { Disabilities }\end{array}$} \\
\hline & $n$ & $\%$ & $n$ & $\%$ \\
\hline $\begin{array}{l}\text { I have completed coursework (All } \\
\text { streams) }\end{array}$ & 8,835 & 20.60 & 483 & 20.78 \\
\hline $\begin{array}{l}\text { I have passed qualifying exams/paper } \\
\text { (Long \& Medium) }\end{array}$ & 4,047 & 9.44 & 155 & 6.67 \\
\hline $\begin{array}{l}\text { I have had my thesis/dissertation } \\
\text { proposal accepted (Long \& Medium) }\end{array}$ & 5,592 & 13.04 & 354 & 15.23 \\
\hline $\begin{array}{l}\text { I have defended my } \\
\text { thesis/dissertation/research paper (Long } \\
\& \text { Medium) }\end{array}$ & 1,208 & 2.82 & 46 & 1.98 \\
\hline \multicolumn{5}{|l|}{ Reason for Enrolling in Current Program } \\
\hline $\begin{array}{l}\text { To equip me to start a career, or advance } \\
\text { an existing career in academia }\end{array}$ & 13,537 & 31.56 & 741 & 31.86 \\
\hline $\begin{array}{l}\text { To equip me to start a career, or advance } \\
\text { an existing career outside of academia }\end{array}$ & 17,654 & 41.23 & 838 & 36.03 \\
\hline $\begin{array}{l}\text { To satisfy my interest in the field, } \\
\text { regardless of career prospects }\end{array}$ & 9,888 & 23.05 & 581 & 24.98 \\
\hline Other (specified) & 1,815 & 4.23 & 166 & 7.14 \\
\hline \multicolumn{5}{|l|}{ Academic Load } \\
\hline Full-time & 35,304 & 82.26 & 1,964 & 84.51 \\
\hline Part-time & 7,611 & 17.74 & 360 & 15.49 \\
\hline \multicolumn{5}{|l|}{ Expect to Graduate in Next Year } \\
\hline Yes & 16,866 & 39.32 & 797 & 34.29 \\
\hline No & 26,029 & 60.68 & 1,527 & 65.71 \\
\hline
\end{tabular}




\section{SECTION 4- GENERAL SATISFACTION}

Table 6

Participants' Responses: Please select your response to the following.

\begin{tabular}{|c|c|c|c|c|c|c|c|c|c|c|c|c|}
\hline & \multicolumn{2}{|c|}{ Definitely } & \multicolumn{2}{|c|}{ Probably } & \multicolumn{2}{|c|}{ Maybe } & \multicolumn{2}{|c|}{ Probably not } & \multicolumn{2}{|c|}{ Definitely not } & \multicolumn{2}{|c|}{ \# of Respondents } \\
\hline & $\begin{array}{c}\text { No } \\
\text { Disability }\end{array}$ & $\begin{array}{c}\text { With } \\
\text { Disability }\end{array}$ & ND & WD & ND & WD & ND & ND & ND & WD & ND & WD \\
\hline $\begin{array}{l}\text { If you were to start your } \\
\text { graduate/professional } \\
\text { career again, would you } \\
\text { select this same } \\
\text { university? }\end{array}$ & 33.84 & 30.44 & 37.21 & 32.46 & 17.85 & 19.82 & 8.07 & 11.31 & 3.02 & 5.98 & 42,897 & 2,326 \\
\hline $\begin{array}{l}\text { If you were to start your } \\
\text { graduate/professional } \\
\text { career again, would you } \\
\text { select the same field of } \\
\text { study? }\end{array}$ & 52.52 & 49.46 & 28.54 & 28.29 & 11.78 & 13.67 & 5.73 & 6.25 & 1.43 & 2.33 & 42,824 & 2,319 \\
\hline $\begin{array}{l}\text { Would you recommend } \\
\text { this university to } \\
\text { someone considering } \\
\text { your program? }\end{array}$ & 43.89 & 37.98 & 30.92 & 28.12 & 15.16 & 17.18 & 6.76 & 10.03 & 3.26 & 6.68 & 42,784 & 2,322 \\
\hline $\begin{array}{l}\text { Would you recommend } \\
\text { this university to } \\
\text { someone in another } \\
\text { field? }\end{array}$ & 26.31 & 23.24 & 36.20 & 30.34 & 29.94 & 34.42 & 5.82 & 8.43 & 1.73 & 3.57 & 42,802 & 2,324 \\
\hline
\end{tabular}




\begin{tabular}{|c|c|c|c|c|c|c|c|c|c|c|c|c|}
\hline & \multicolumn{2}{|c|}{ Definitely } & \multicolumn{2}{|c|}{ Probably } & \multicolumn{2}{|c|}{ Maybe } & \multicolumn{2}{|c|}{ Probably not } & \multicolumn{2}{|c|}{ Definitely not } & \multicolumn{2}{|c|}{ \# of Respondents } \\
\hline & $\begin{array}{c}\text { No } \\
\text { Disability }\end{array}$ & $\begin{array}{c}\text { With } \\
\text { Disability }\end{array}$ & ND & WD & ND & WD & ND & $\mathrm{ND}$ & ND & WD & ND & WD \\
\hline $\begin{array}{l}\text { If you were to start your } \\
\text { graduate career again, } \\
\text { would you select the } \\
\text { same faculty } \\
\text { supervisor? (Long } \\
\text { stream only) }\end{array}$ & 53.90 & 52.40 & 22.75 & 20.62 & 11.08 & 10.16 & 7.04 & 8.59 & 5.23 & 8.23 & 25,878 & 1,397 \\
\hline
\end{tabular}


If you were to start your graduate/ professional career again, would you select this same university?

No Disability

With Disability

If you were to start your graduate/ professional career again, would you select the same field of study?

Would you recommend this university to someone considering your program?

Would you recommend this university to someone in another field?

If you were to start your graduate

career again, would you select the same

faculty supervisor? (Long stream only)

With Disability

With Disability

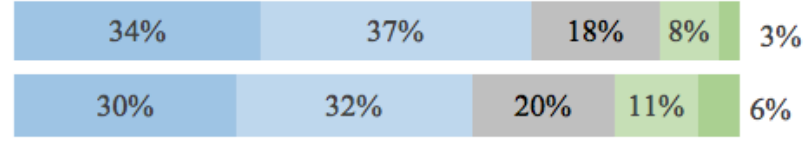

\begin{tabular}{|r|r|r|r|r|}
\hline $53 \%$ & $29 \%$ & $12 \%$ & $6 \%$ & $1 \%$ \\
\hline $49 \%$ & $28 \%$ & $14 \%$ & $6 \%$ & $2 \%$ \\
\hline
\end{tabular}

\begin{tabular}{|l|l|l|l|l|}
\hline $44 \%$ & $31 \%$ & $15 \%$ & $7 \%$ & $3 \%$ \\
\hline $38 \%$ & $28 \%$ & $17 \%$ & $10 \%$ & $7 \%$ \\
\hline
\end{tabular}

\begin{tabular}{|l|l|l|l|l|}
\hline $26 \%$ & $36 \%$ & $30 \%$ & $6 \%$ & $2 \%$ \\
\hline $23 \%$ & $30 \%$ & $34 \%$ & $8 \%$ & $4 \%$ \\
\hline
\end{tabular}

No Disability With Disability

No Disability

With Disability

Wo Disability

No Disability

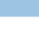

\begin{tabular}{|c|c|c|}
\hline $54 \%$ & $23 \%$ & $11 \% \quad 7 \% 5 \%$ \\
\hline $52 \%$ & $21 \%$ & $10 \% \quad 9 \% \quad 8 \%$ \\
\hline
\end{tabular}

Definitely
Maybe $\quad$ Probably Not $\square$ Definitely Not 
SECTION 5- SATISFACTION WITH PROGRAM, QUALITY OF INTERACTIONS, AND

COURSEWORK

Table 7

Participants' Responses: Please rate the following dimensions of your program.

\begin{tabular}{|c|c|c|c|c|c|c|c|c|c|c|c|c|}
\hline & \multicolumn{2}{|c|}{ Excellent } & \multicolumn{2}{|c|}{ Very Good } & \multicolumn{2}{|c|}{ Good } & \multicolumn{2}{|c|}{ Fair } & \multicolumn{2}{|c|}{ Poor } & \multicolumn{2}{|c|}{ \# of Respondents } \\
\hline & $\begin{array}{c}\text { No } \\
\text { Disability }\end{array}$ & $\begin{array}{c}\text { With } \\
\text { Disability }\end{array}$ & ND & WD & ND & WD & ND & WD & ND & WD & ND & WD \\
\hline $\begin{array}{l}\text { The intellectual quality of } \\
\text { the faculty }\end{array}$ & 42.06 & 42.77 & 39.80 & 37.95 & 13.82 & 13.98 & 3.42 & 4.22 & 0.89 & 1.08 & 42,854 & 2,324 \\
\hline $\begin{array}{l}\text { The intellectual quality of } \\
\text { my fellow students }\end{array}$ & 22.25 & 24.10 & 44.05 & 40.17 & 25.33 & 24.62 & 6.98 & 8.51 & 1.40 & 2.59 & 42,740 & 2,315 \\
\hline $\begin{array}{l}\text { The relationship between } \\
\text { faculty and graduate students }\end{array}$ & 26.55 & 21.35 & 37.47 & 32.41 & 24.00 & 27.38 & 8.86 & 12.61 & 3.12 & 6.24 & 42,745 & 2,323 \\
\hline $\begin{array}{l}\text { Overall quality of graduate } \\
\text { level teaching by faculty }\end{array}$ & 20.93 & 19.46 & 41.80 & 38.44 & 25.46 & 26.23 & 9.14 & 11.17 & 2.67 & 4.70 & 42,738 & 2,318 \\
\hline $\begin{array}{l}\text { Advice on the availability of } \\
\text { financial support }\end{array}$ & 10.24 & 8.55 & 21.58 & 17.19 & 32.40 & 28.04 & 22.59 & 24.74 & 13.20 & 21.48 & 42,417 & 2,304 \\
\hline $\begin{array}{l}\text { Quality of academic } \\
\text { advising and guidance }\end{array}$ & 17.44 & 15.70 & 29.28 & 23.88 & 30.27 & 27.64 & 15.91 & 19.29 & 7.10 & 13.49 & 42,570 & 2,312 \\
\hline $\begin{array}{l}\text { Helpfulness of staff } \\
\text { members in my program }\end{array}$ & 29.49 & 32.70 & 33.99 & 30.03 & 23.12 & 20.70 & 9.71 & 11.02 & 3.69 & 5.55 & 42,727 & 2,324 \\
\hline
\end{tabular}




\begin{tabular}{|c|c|c|c|c|c|c|c|c|c|c|c|c|}
\hline & \multicolumn{2}{|c|}{ Excellent } & \multicolumn{2}{|c|}{ Very Good } & \multicolumn{2}{|c|}{ Good } & \multicolumn{2}{|c|}{ Fair } & \multicolumn{2}{|c|}{ Poor } & \multicolumn{2}{|c|}{ \# of Respondents } \\
\hline & $\begin{array}{c}\text { No } \\
\text { Disability }\end{array}$ & $\begin{array}{c}\text { With } \\
\text { Disability }\end{array}$ & ND & WD & ND & WD & ND & WD & ND & WD & ND & WD \\
\hline $\begin{array}{l}\text { Availability of area courses I } \\
\text { needed to complete my } \\
\text { program }\end{array}$ & 19.43 & 18.68 & 29.25 & 26.29 & 27.92 & 25.94 & 15.37 & 18.29 & 8.03 & 10.81 & 42,669 & 2,313 \\
\hline $\begin{array}{l}\text { Quality of instruction in my } \\
\text { courses }\end{array}$ & 20.07 & 19.07 & 41.46 & 38.70 & 27.00 & 27.01 & 9.13 & 11.35 & 2.34 & 3.88 & 42,735 & 2,318 \\
\hline $\begin{array}{l}\text { Relationship of program } \\
\text { content to my } \\
\text { research/professional goals }\end{array}$ & 20.49 & 18.42 & 35.03 & 30.76 & 27.80 & 27.78 & 12.31 & 15.70 & 4.37 & 7.33 & 42,766 & 2,318 \\
\hline $\begin{array}{l}\text { Opportunities for student } \\
\text { collaboration or teamwork }\end{array}$ & 22.71 & 19.30 & 32.44 & 27.89 & 26.28 & 26.42 & 12.47 & 15.76 & 6.11 & 10.62 & 42,712 & 2,316 \\
\hline $\begin{array}{l}\text { Opportunities to take } \\
\text { coursework outside my own } \\
\text { department }\end{array}$ & 14.19 & 14.04 & 24.69 & 20.77 & 30.28 & 27.25 & 18.47 & 21.08 & 12.37 & 16.86 & 42,194 & 2,301 \\
\hline $\begin{array}{l}\text { Opportunities to engage in } \\
\text { interdisciplinary work }\end{array}$ & 15.50 & 17.96 & 25.04 & 21.27 & 30.54 & 27.88 & 19.02 & 19.14 & 9.90 & 13.75 & 42,249 & 2,299 \\
\hline Amount of coursework & 12.17 & 10.10 & 35.83 & 30.64 & 39.50 & 41.17 & 10.16 & 13.47 & 2.34 & 4.62 & 42,698 & 2,317 \\
\hline
\end{tabular}




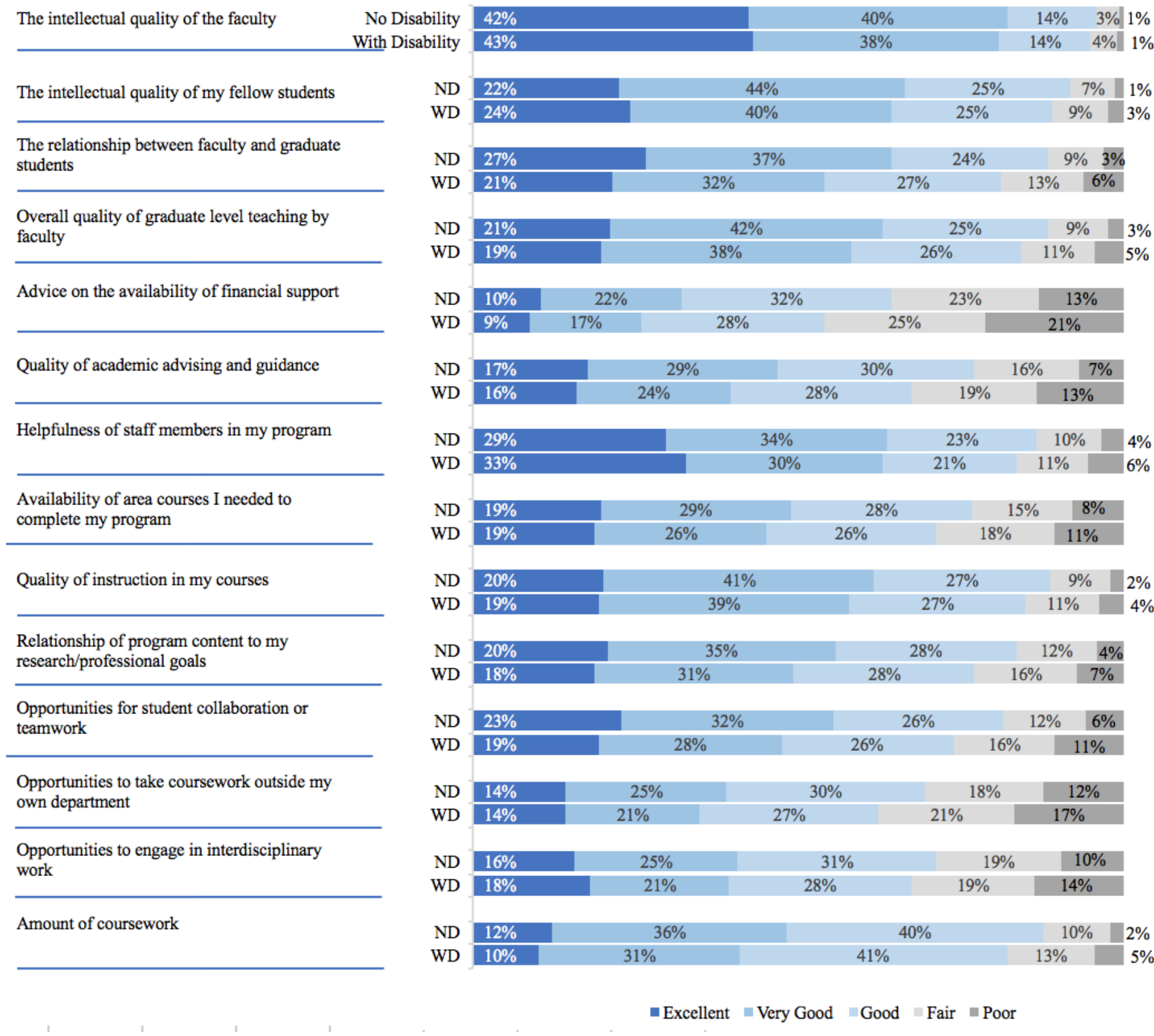




\section{SECTION 6- PROFESSIONAL SKILLS DEVELOPMENT}

Table 8

Participants' Responses: How would you rate the quality of the support and training you received in these areas? (Long and Medium Streams only)

\begin{tabular}{|c|c|c|c|c|c|c|c|c|c|c|c|c|c|c|c|c|}
\hline & \multicolumn{2}{|c|}{ Excellent } & \multicolumn{2}{|c|}{ Very Good } & \multicolumn{2}{|c|}{ Good } & \multicolumn{2}{|c|}{ Fair } & \multicolumn{2}{|c|}{ Poor } & \multicolumn{2}{|c|}{ Did not Participate } & \multicolumn{2}{|c|}{ Not Applicable } & \multicolumn{2}{|c|}{ \# of Respondents } \\
\hline & $\begin{array}{c}\text { No } \\
\text { Disability }\end{array}$ & $\begin{array}{l}\text { With a } \\
\text { Disability }\end{array}$ & ND & WD & ND & WD & ND & WD & ND & WD & ND & WD & ND & WD & ND & WD \\
\hline $\begin{array}{l}\text { Courses, } \\
\text { workshops, or } \\
\text { orientation on } \\
\text { teaching }\end{array}$ & 14.05 & 12.45 & 26.55 & 21.29 & 24.26 & 22.09 & 10.53 & 12.27 & 4.80 & 10.49 & 13.02 & 12.09 & 6.79 & 9.33 & 28,575 & 1,630 \\
\hline $\begin{array}{l}\text { Advice/workshops } \\
\text { on preparing for } \\
\text { candidacy } \\
\text { examinations }\end{array}$ & 7.54 & 4.61 & 14.44 & 9.83 & 17.23 & 11.98 & 10.67 & 10.32 & 8.12 & 13.70 & 20.39 & 18.98 & 21.60 & 30.59 & 28,483 & 1,628 \\
\hline $\begin{array}{l}\text { Feedback on your } \\
\text { research }\end{array}$ & 19.00 & 16.57 & 27.35 & 23.63 & 25.00 & 23.51 & 12.01 & 13.57 & 5.18 & 9.82 & 5.20 & 4.24 & 6.26 & 8.66 & 28,518 & 1,629 \\
\hline $\begin{array}{l}\text { Advice/workshops } \\
\text { on standards for } \\
\text { academic writing in } \\
\text { your field }\end{array}$ & 9.85 & 8.37 & 18.21 & 14.52 & 21.37 & 18.83 & 13.10 & 15.14 & 8.34 & 13.91 & 22.16 & 20.74 & 6.96 & 8.49 & 28,473 & 1,625 \\
\hline $\begin{array}{l}\text { Advice/workshops } \\
\text { on standards for } \\
\text { writing grant } \\
\text { proposals }\end{array}$ & 8.02 & 7.31 & 14.12 & 11.49 & 17.86 & 16.83 & 13.48 & 14.00 & 10.76 & 17.01 & 25.00 & 22.79 & 10.75 & 10.57 & 28,469 & 1,628 \\
\hline $\begin{array}{l}\text { Advice/workshops } \\
\text { on publishing your } \\
\text { work }\end{array}$ & 7.85 & 5.18 & 13.28 & 8.32 & 17.51 & 14.73 & 13.39 & 13.80 & 11.72 & 21.57 & 25.52 & 24.65 & 10.73 & 11.77 & 28,371 & 1,623 \\
\hline $\begin{array}{l}\text { Advice/workshops } \\
\text { on job searching } \\
\text { (CV prep, } \\
\text { interview skills, } \\
\text { etc.) }\end{array}$ & 6.62 & 4.30 & 11.89 & 8.60 & 16.66 & 13.94 & 13.19 & 14.00 & 12.58 & 20.33 & 28.13 & 26.23 & 10.93 & 12.59 & 28,477 & 1,628 \\
\hline
\end{tabular}




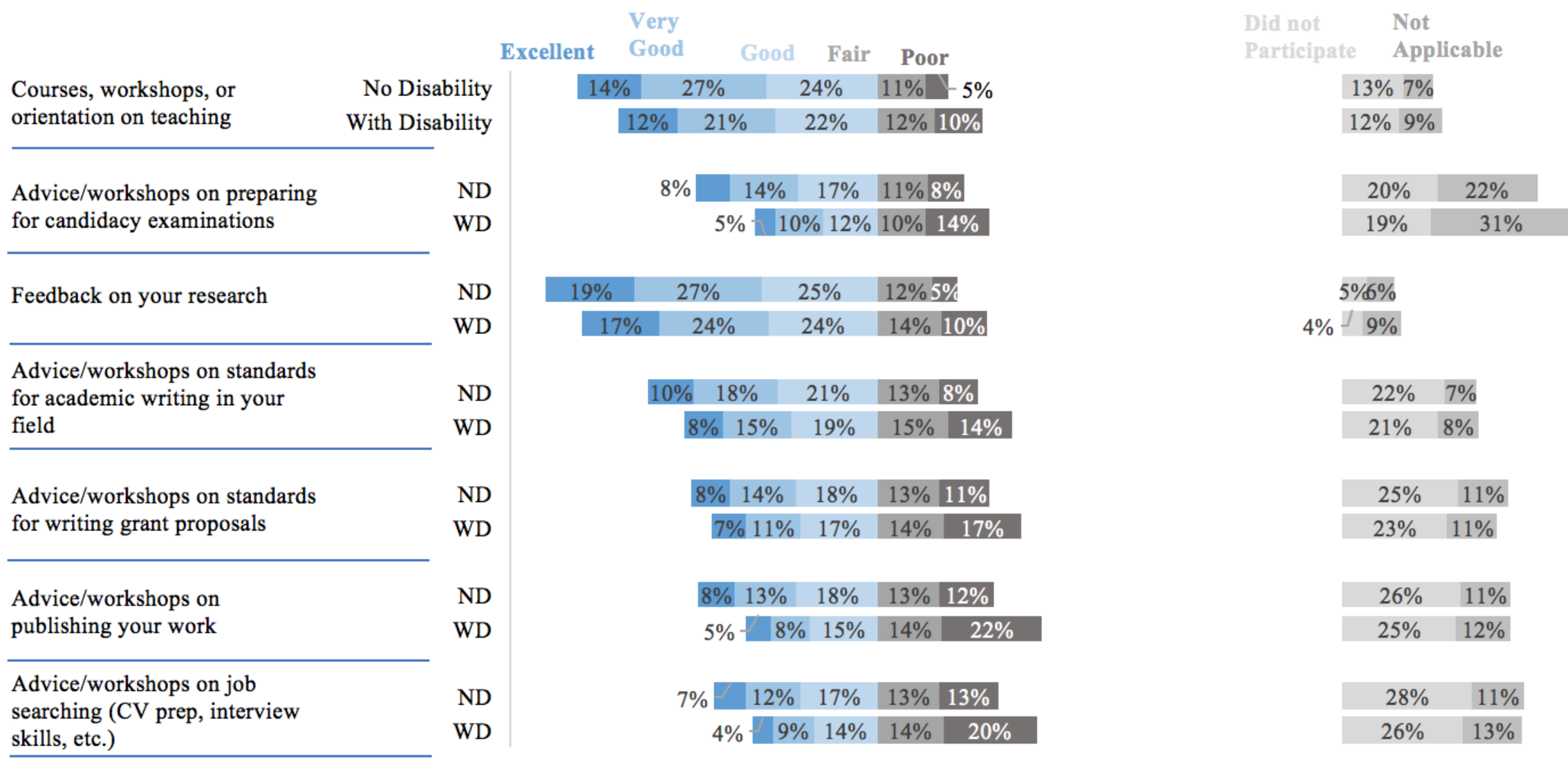


Table 9

Participants' Responses: How would you rate the quality of the support and training you received in these areas? (Long and Medium Streams only)

\begin{tabular}{|c|c|c|c|c|c|c|c|c|c|c|c|c|c|c|c|c|}
\hline & \multicolumn{2}{|c|}{ Excellent } & \multicolumn{2}{|c|}{ Very Good } & \multicolumn{2}{|c|}{ Good } & \multicolumn{2}{|c|}{ Fair } & \multicolumn{2}{|c|}{ Poor } & \multicolumn{2}{|c|}{ Did not Participate } & \multicolumn{2}{|c|}{ Not Applicable } & \multicolumn{2}{|c|}{ \# of Respondents } \\
\hline & $\begin{array}{c}\text { No } \\
\text { Disability }\end{array}$ & $\begin{array}{c}\text { With a } \\
\text { Disability }\end{array}$ & ND & WD & ND & WD & $\mathrm{ND}$ & WD & ND & WD & ND & WD & ND & WD & ND & WD \\
\hline $\begin{array}{l}\text { Advice/workshops } \\
\text { on career options } \\
\text { within academia? }\end{array}$ & 6.61 & 4.48 & 13.49 & 10.20 & 19.48 & 17.32 & 14.54 & 15.60 & 12.87 & 21.31 & 24.23 & 22.17 & 8.79 & 8.91 & 28,471 & 1,628 \\
\hline $\begin{array}{l}\text { Advice/workshops } \\
\text { on career options } \\
\text { outside of } \\
\text { academia }\end{array}$ & 4.61 & 3.14 & 10.73 & 7.94 & 17.99 & 17.35 & 17.12 & 17.35 & 17.23 & 27.45 & 23.80 & 21.54 & 8.51 & 8.55 & 28,422 & 1,625 \\
\hline $\begin{array}{l}\text { Advice/workshops } \\
\text { about research } \\
\text { positions }\end{array}$ & 4.89 & 3.51 & 10.25 & 6.58 & 18.13 & 15.08 & 16.41 & 16.06 & 15.60 & 26.89 & 24.87 & 21.29 & 9.84 & 10.58 & 28,299 & 1,625 \\
\hline $\begin{array}{l}\text { Advice/workshops } \\
\text { about research } \\
\text { ethics in human } \\
\text { subject research }\end{array}$ & 8.08 & 8.56 & 14.71 & 13.49 & 17.74 & 17.56 & 10.45 & 9.92 & 6.40 & 11.15 & 21.52 & 18.05 & 21.09 & 21.26 & 28,351 & 1,623 \\
\hline $\begin{array}{l}\text { Advice/workshops } \\
\text { about research } \\
\text { ethics in the use of } \\
\text { animals }\end{array}$ & 4.79 & 3.65 & 8.01 & 4.33 & 9.94 & 6.86 & 6.33 & 4.45 & 4.82 & 7.54 & 25.60 & 20.52 & 40.51 & 52.66 & 28,321 & 1,618 \\
\hline $\begin{array}{l}\text { Advice/workshops } \\
\text { on intellectual } \\
\text { property issues }\end{array}$ & 7.21 & 7.57 & 13.63 & 10.28 & 19.09 & 16.13 & 12.27 & 12.19 & 10.78 & 18.41 & 23.60 & 20.01 & 13.42 & 15.39 & 28,373 & 1,624 \\
\hline
\end{tabular}




\begin{tabular}{lr}
$\begin{array}{l}\text { Advice/workshops on career } \\
\text { options within academia }\end{array}$ & $\begin{array}{r}\text { No Disability } \\
\text { With Disability }\end{array}$ \\
\hline $\begin{array}{l}\text { Advice/workshops on career } \\
\text { options outside of academia }\end{array}$ & $\begin{array}{c}\text { No Disability } \\
\text { With Disability }\end{array}$ \\
\hline $\begin{array}{l}\text { Advice/workshops about } \\
\text { research positions }\end{array}$ & No Disability \\
\hline $\begin{array}{l}\text { Advice/workshops about } \\
\text { research ethics in human subject } \\
\text { research }\end{array}$ & No Disability \\
\hline $\begin{array}{l}\text { With Disability } \\
\text { Advice/workshops about } \\
\text { research ethics in the use of } \\
\text { animals }\end{array}$ & No Disability \\
\hline $\begin{array}{l}\text { Advice/workshops on } \\
\text { intellectual property issues }\end{array}$ & No Disability \\
\hline
\end{tabular}

Excellent Good Good Fair Poor

\begin{tabular}{|l|l|l|l|l|}
\hline $7 \%$ & $13 \%$ & $19 \%$ & $15 \%$ & $13 \%$ \\
\hline
\end{tabular}

\begin{tabular}{|l|l|l|l|l|}
$4 \%$ & $10 \%$ & $17 \%$ & $16 \%$ & $21 \%$ \\
\hline
\end{tabular}

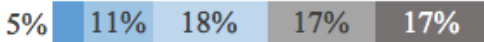

\begin{tabular}{|l|l|l|l}
\hline $3 \%$ & $8 \%$ & $17 \%$ & $27 \%$ \\
\hline
\end{tabular}
$17 \%$

\begin{tabular}{|l|l|l|l|l|}
\hline $5 \%$ & $10 \%$ & $18 \%$ & $16 \%$ & $16 \%$ \\
\hline
\end{tabular}

\begin{tabular}{|l|l|l|l|l|}
\hline $4 \%$ & $7 \%$ & $15 \%$ & $16 \%$ & $27 \%$ \\
\hline
\end{tabular}

\begin{tabular}{|l|l|l|l|}
\hline $8 \%$ & $15 \%$ & $18 \%$ & $10 \% 6 \%$ \\
\hline $9 \%$ & $13 \%$ & $18 \%$ & $10 \%$ \\
\hline
\end{tabular}

$6 \%$

$5 \% \quad 8 \% 10 \% \quad 5 \%$

4\% $\quad 7 \% \quad 8 \%$

$4 \% \quad 4 \%$

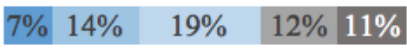

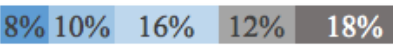

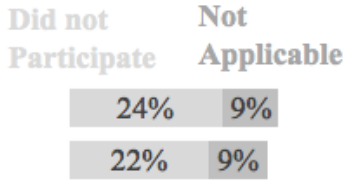

\begin{tabular}{|c|c|}
\hline $26 \%$ & $41 \%$ \\
\hline $21 \%$ & $53 \%$ \\
\hline
\end{tabular}

$24 \% \quad 13 \%$

$20 \% \quad 15 \%$ 
Table 10

Participants' Responses: How would you rate the quality of the support and training you received in these areas? (Short Stream only)

\begin{tabular}{|c|c|c|c|c|c|c|c|c|c|c|c|c|c|c|c|c|}
\hline & \multicolumn{2}{|c|}{ Excellent } & \multicolumn{2}{|c|}{ Very Good } & \multicolumn{2}{|c|}{ Good } & \multicolumn{2}{|c|}{ Fair } & \multicolumn{2}{|c|}{ Poor } & \multicolumn{2}{|c|}{ Did not Participate } & \multicolumn{2}{|c|}{ Not Applicable } & \multicolumn{2}{|c|}{ \# of Respondents } \\
\hline & $\begin{array}{c}\text { No } \\
\text { Disability }\end{array}$ & $\begin{array}{l}\text { With a } \\
\text { Disability }\end{array}$ & ND & WD & ND & WD & $\mathrm{ND}$ & WD & ND & WD & ND & WD & ND & WD & ND & WD \\
\hline $\begin{array}{l}\text { Advice/workshops } \\
\text { on the standards for } \\
\text { writing in your } \\
\text { profession }\end{array}$ & 9.34 & 8.43 & 19.85 & 15.99 & 23.14 & 20.93 & 11.36 & 15.55 & 5.16 & 8.14 & 21.38 & 22.67 & 9.77 & 8.28 & 14,162 & 688 \\
\hline $\begin{array}{l}\text { Advice/workshops } \\
\text { on career options }\end{array}$ & 7.98 & 7.12 & 16.22 & 13.52 & 22.13 & 22.38 & 14.95 & 17.73 & 9.65 & 12.79 & 19.31 & 16.86 & 9.77 & 9.59 & 14,119 & 688 \\
\hline $\begin{array}{l}\text { Advice/workshops } \\
\text { on professional } \\
\text { ethics }\end{array}$ & 11.56 & 12.15 & 20.36 & 19.47 & 22.88 & 23.57 & 11.89 & 12.01 & 4.94 & 9.22 & 18.46 & 15.37 & 9.91 & 8.20 & 14,070 & 683 \\
\hline $\begin{array}{l}\text { Advice/workshops } \\
\text { on job preparation } \\
\text { and professional } \\
\text { practice }\end{array}$ & 9.57 & 9.33 & 17.02 & 16.15 & 22.21 & 20.74 & 14.30 & 16.74 & 9.30 & 12.44 & 18.07 & 16.15 & 9.52 & 8.44 & 14,038 & 675 \\
\hline $\begin{array}{l}\text { Opportunities for } \\
\text { internships, } \\
\text { practicum, and } \\
\text { experiential } \\
\text { learning as part of } \\
\text { the program }\end{array}$ & 17.17 & 21.75 & 18.76 & 18.83 & 17.48 & 18.83 & 11.75 & 12.85 & 11.69 & 12.12 & 12.61 & 6.72 & 10.53 & 8.91 & 14,093 & 685 \\
\hline $\begin{array}{l}\text { Opportunities for } \\
\text { contact (lectures, } \\
\text { seminars, } \\
\text { discussion) with } \\
\text { practicing } \\
\text { professionals }\end{array}$ & 17.76 & 18.80 & 24.55 & 26.24 & 24.15 & 22.59 & 12.88 & 13.12 & 6.32 & 8.75 & 9.16 & 6.41 & 5.17 & 4.08 & 14,136 & 686 \\
\hline
\end{tabular}




\begin{tabular}{lr}
$\begin{array}{l}\text { Advice/workshops on the } \\
\text { standards for writing in your } \\
\text { profession }\end{array}$ & $\begin{array}{r}\text { No Disability } \\
\text { With Disability }\end{array}$ \\
\hline $\begin{array}{l}\text { Advice/workshops on career } \\
\text { options }\end{array}$ & $\begin{array}{r}\text { No Disability } \\
\text { With Disability }\end{array}$ \\
\hline $\begin{array}{l}\text { Advice/workshops on } \\
\text { professional ethics }\end{array}$ & No Disability \\
\hline $\begin{array}{l}\text { Advice/workshops on job } \\
\text { preparation and professional } \\
\text { practice }\end{array}$ & Wo Disability \\
\hline $\begin{array}{l}\text { Opportunities for internships, } \\
\text { practicum, and experiential } \\
\text { learning as part of the program }\end{array}$ & With Disability \\
\hline $\begin{array}{l}\text { Opportunities for contact } \\
\text { (lectures, seminars, discussion) } \\
\text { with practicing professionals }\end{array}$ & Wo Dith Disability \\
\hline
\end{tabular}

\begin{tabular}{|c|c|c|c|}
\hline & $\begin{array}{l}\text { Very } \\
\text { Good }\end{array}$ & & Fair \\
\hline \multirow[t]{2}{*}{$9 \%$} & $20 \%$ & $\begin{array}{l}\text { Good } \\
23 \%\end{array}$ & $11 \% 5 \%$ \\
\hline & $16 \%$ & $21 \%$ & $16 \% \quad 8 \%$ \\
\hline & $16 \%$ & $22 \%$ & $15 \% \quad 10 \%$ \\
\hline & $14 \%$ & $22 \%$ & $18 \%$ \\
\hline & $20 \%$ & $23 \%$ & $12 \% \quad 5 \%$ \\
\hline & $9 \%$ & $24 \%$ & $12 \% \quad 9 \%$ \\
\hline & $17 \%$ & $22 \%$ & $14 \% \quad 9 \%$ \\
\hline & $16 \%$ & $21 \%$ & $17 \% \quad 12 \%$ \\
\hline & $19 \%$ & $17 \%$ & $12 \% \quad 12 \%$ \\
\hline & $19 \%$ & $19 \%$ & $13 \% \quad 12 \%$ \\
\hline $18 \%$ & $\%$ & $24 \%$ & $13 \% \quad 6 \%$ \\
\hline $19 \%$ & $\%$ & $23 \%$ & $13 \% \quad 9 \%$ \\
\hline
\end{tabular}

\begin{tabular}{|r|r|}
\hline Did not & \multicolumn{1}{|c|}{ Not } \\
Participate & \multicolumn{1}{|c|}{ Applicable } \\
\hline $21 \%$ & $10 \%$ \\
\hline $23 \%$ & $8 \%$ \\
\hline $19 \%$ & $10 \%$ \\
\hline $17 \%$ & $10 \%$ \\
\hline $18 \%$ & $10 \%$ \\
\hline $15 \%$ & $8 \%$ \\
\hline $18 \%$ & $10 \%$ \\
\hline $16 \%$ & $8 \%$ \\
\hline $13 \%$ & $11 \%$ \\
\hline $7 \%$ & $9 \%$ \\
\hline $6 \%$ & \\
\hline $6 \%$ & \\
\hline
\end{tabular}


SECTION 7- RESEARCH EXPERIENCE

Table 11

Participants' Responses: How would you rate the quality of the support and opportunities you received in these areas?

\begin{tabular}{|c|c|c|c|c|c|c|c|c|c|c|c|c|c|c|c|c|}
\hline & \multicolumn{2}{|c|}{ Excellent } & \multicolumn{2}{|c|}{ Very Good } & \multicolumn{2}{|c|}{ Good } & \multicolumn{2}{|c|}{ Fair } & \multicolumn{2}{|r|}{ Poor } & \multicolumn{2}{|c|}{$\begin{array}{c}\text { Did not } \\
\text { Participate }\end{array}$} & \multicolumn{2}{|c|}{$\begin{array}{c}\text { Not } \\
\text { Applicable }\end{array}$} & \multicolumn{2}{|c|}{$\begin{array}{c}\text { \# of } \\
\text { Respondents }\end{array}$} \\
\hline & $\begin{array}{c}\text { No } \\
\text { Disability }\end{array}$ & $\begin{array}{c}\text { With a } \\
\text { Disability }\end{array}$ & ND & WD & ND & WD & ND & WD & ND & WD & ND & WD & ND & WD & ND & WD \\
\hline $\begin{array}{l}\text { Conducting } \\
\text { independent } \\
\text { research since } \\
\text { starting your } \\
\text { graduate } \\
\text { program }\end{array}$ & 18.28 & 17.67 & 24.39 & 19.48 & 21.60 & 20.30 & 9.84 & 12.46 & 5.87 & 11.81 & 7.33 & 5.91 & 12.70 & 12.37 & 42,693 & 2,320 \\
\hline $\begin{array}{l}\text { Training in } \\
\text { research } \\
\text { methods } \\
\text { before } \\
\text { beginning } \\
\text { your own } \\
\text { research }\end{array}$ & 12.59 & 11.14 & 19.97 & 18.00 & 23.43 & 21.06 & 14.43 & 16.53 & 11.05 & 16.10 & 7.20 & 6.13 & 11.33 & 11.05 & 42,666 & 2,317 \\
\hline $\begin{array}{l}\text { Faculty } \\
\text { guidance in } \\
\text { formulating a } \\
\text { research topic }\end{array}$ & 19.19 & 18.13 & 22.83 & 19.21 & 21.32 & 20.07 & 12.13 & 14.30 & 7.64 & 12.70 & 5.39 & 4.61 & 11.50 & 10.98 & 42,692 & 2,322 \\
\hline
\end{tabular}




\begin{tabular}{ll|}
$\begin{array}{l}\text { Conducting independent } \\
\text { research since starting your } \\
\text { graduate program }\end{array}$ & No Disability \\
\hline & With Disability \\
$\begin{array}{l}\text { Training in research methods } \\
\text { before beginning your own } \\
\text { research }\end{array}$ & No Disability \\
\hline & Nisability \\
\hline $\begin{array}{l}\text { Faculty guidance in formulating } \\
\text { a research topic }\end{array}$ & No Disability \\
\hline
\end{tabular}

Excellent Very Good Good Fair Poor

\begin{tabular}{|c|c|c|c|c|}
\hline $18 \%$ & $24 \%$ & $22 \%$ & $10 \% 6$ & \\
\hline $18 \%$ & $19 \%$ & $20 \%$ & $12 \%$ & $12 \%$ \\
\hline
\end{tabular}

\begin{tabular}{|c|c|c|c|c|}
\hline $13 \%$ & $20 \%$ & $23 \%$ & $14 \%$ & $11 \%$ \\
\hline $11 \%$ & $18 \%$ & $21 \%$ & $17 \%$ & $16 \%$ \\
\hline
\end{tabular}

\begin{tabular}{|c|c|c|c|c|}
\hline $19 \%$ & $23 \%$ & $21 \%$ & $12 \%$ & $8 \%$ \\
\hline $18 \%$ & $19 \%$ & $20 \%$ & $14 \%$ & $13 \%$ \\
\hline
\end{tabular}

$7 \% 11 \%$

$6 \% 11 \%$

Did not Not

Participate Applicable

$\begin{array}{lll}7 \% & 13 \%\end{array}$

$6 \% 12 \%$

$5 \% 12 \%$

$5 \% 11 \%$ 
Table 12

Participants' Responses: How would you rate the quality of the support and opportunities you received in these areas? (Long and Medium Streams only)

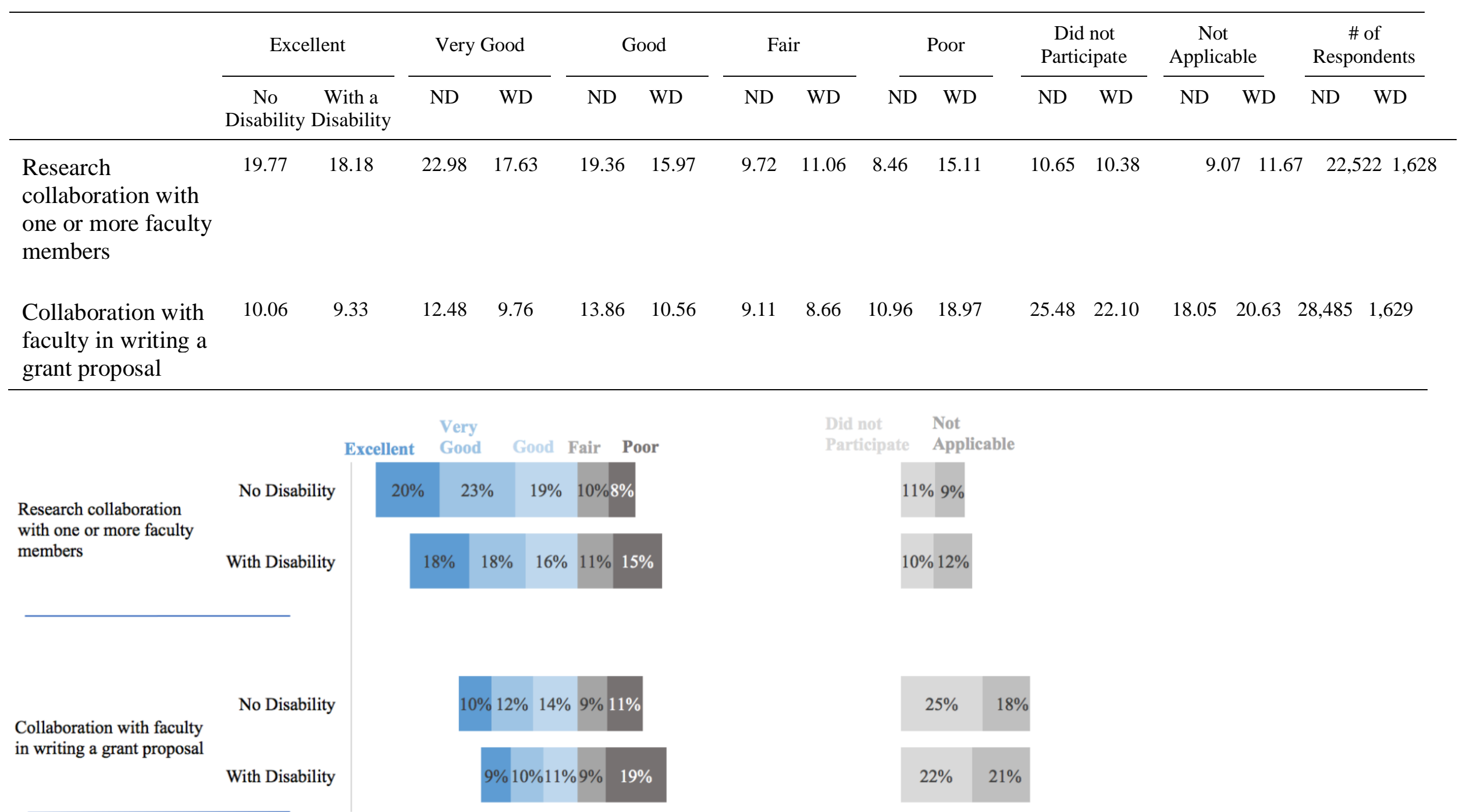




\section{SECTION 8- PRESENTATIONS AND PUBLICATIONS}

Table 13

Participants' responses: Please select if the following occurs in your department.

\begin{tabular}{|c|c|c|c|c|c|c|c|c|}
\hline & \multicolumn{4}{|c|}{ Students without Disabilities } & \multicolumn{4}{|c|}{ Students with Disabilities } \\
\hline & \multicolumn{2}{|c|}{ No } & \multicolumn{2}{|c|}{ Yes } & \multicolumn{2}{|c|}{ No } & \multicolumn{2}{|c|}{ Yes } \\
\hline & $n$ & $\%$ & $n$ & $\%$ & $n$ & $\%$ & $n$ & $\%$ \\
\hline $\begin{array}{l}\text { Seminars/colloquia at } \\
\text { which students present } \\
\text { their research }\end{array}$ & 10,499 & 24.65 & 32,088 & 65.35 & 572 & 24.75 & 1,739 & 75.25 \\
\hline $\begin{array}{l}\text { Departmental funding for } \\
\text { students to attend } \\
\text { national or regional } \\
\text { meetings }\end{array}$ & 21,387 & 50.55 & 20,922 & 49.45 & 1,145 & 49.70 & 1,159 & 50.30 \\
\hline $\begin{array}{l}\text { Attend national scholarly } \\
\text { meetings }\end{array}$ & 22,823 & 54.03 & 19,418 & 45.97 & 1,230 & 53.39 & 1,074 & 46.61 \\
\hline
\end{tabular}

If participants responded 'Yes' they were then asked to provide the number of occurrences.

\begin{tabular}{|c|c|c|c|c|}
\hline \multirow[t]{2}{*}{$\begin{array}{l}\text { Seminars/colloquia } \\
\text { at which students } \\
\text { present their } \\
\text { research }\end{array}$} & \multicolumn{2}{|c|}{$\begin{array}{l}\text { Students without } \\
\text { Disabilities } \\
(\mathrm{N}=31,012)\end{array}$} & \multicolumn{2}{|c|}{$\begin{array}{c}\text { Students with } \\
\text { Disabilities } \\
(\mathrm{N}=1,697)\end{array}$} \\
\hline & $n$ & $\%$ & $n$ & $\%$ \\
\hline 0 & 6,629 & 21.38 & 409 & 24.10 \\
\hline 1 & 6,558 & 21.15 & 396 & 23.34 \\
\hline 2 & 5,460 & 17.61 & 299 & 17.62 \\
\hline 3 & 2,641 & 8.52 & 153 & 9.02 \\
\hline $4+$ & 9,724 & 31.36 & 440 & 25.93 \\
\hline
\end{tabular}




\begin{tabular}{|c|c|c|c|c|}
\hline \multirow[t]{2}{*}{$\begin{array}{l}\text { Departmental } \\
\text { funding for } \\
\text { students to attend } \\
\text { national or regional } \\
\text { meetings }\end{array}$} & \multicolumn{2}{|c|}{$\begin{array}{l}\text { Students without } \\
\text { Disabilities } \\
(\mathrm{N}=20,064)\end{array}$} & \multicolumn{2}{|c|}{$\begin{array}{l}\text { Students with } \\
\text { Disabilities } \\
(\mathrm{N}=1,125)\end{array}$} \\
\hline & $n$ & $\%$ & $n$ & $\%$ \\
\hline 0 & 9,462 & 47.16 & 559 & 49.69 \\
\hline 1 & 5,530 & 27.56 & 290 & 25.78 \\
\hline 2 & 2,528 & 12.60 & 156 & 13.87 \\
\hline 3 & 1,134 & 5.65 & 45 & 4.00 \\
\hline $4+$ & 1,410 & 7.03 & 75 & 6.67 \\
\hline
\end{tabular}

\begin{tabular}{lccccc}
\hline $\begin{array}{l}\text { Attend national } \\
\text { scholarly meetings }\end{array}$ & \multicolumn{2}{c}{$\begin{array}{c}\text { Students without } \\
\text { Disabilities }\end{array}$} & & \multicolumn{2}{c}{$\begin{array}{c}\text { Students with } \\
\text { Disabilities } \\
(\mathrm{N}=1,050)\end{array}$} \\
\cline { 2 - 3 } \cline { 5 - 6 } & $n$ & & & & \\
\cline { 2 - 3 } \cline { 5 - 6 } & 7,136 & 38.23 & & 414 & 39.43 \\
1 & 4,621 & 24.76 & & 244 & 23.24 \\
2 & 2,660 & 14.25 & & 164 & 15.62 \\
3 & 1,476 & 7.91 & & 70 & 6.67 \\
$4+$ & 2,772 & 14.85 & & 158 & 15.05 \\
\hline
\end{tabular}


Seminars/colloquia at which students present their research

Departmental funding for students to attend national or regional meetings

Attend national scholarly meetings
$65 \%$

$75 \%$

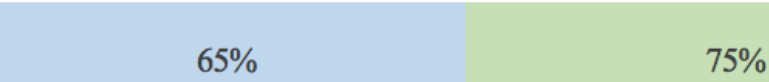

$49 \%$

$50 \%$

$46 \%$

$47 \%$

No Disability With Disability

If participants responded 'Yes' they were then asked to provide the number of occurences.

Seminars/colloquia at which students present their research
Departmental funding for students to attend national or regional meetings
Attend national or regional meetings

$60 \%$
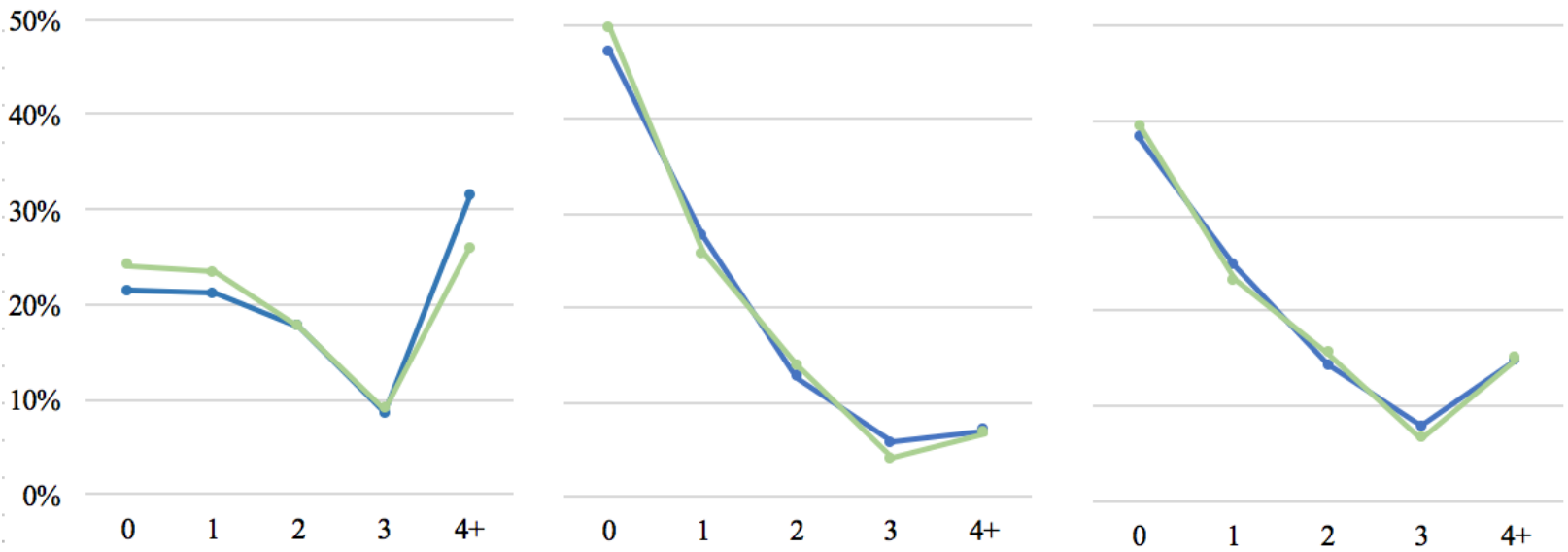

$\begin{array}{lllll}0 & 1 & 2 & 3 & 4+\end{array}$

0

$\longrightarrow$ Students with Disabilities 
Table 14

Participants' responses: Please select if the following occurs in your department (Long Stream only)

\begin{tabular}{|c|c|c|c|c|c|c|c|c|}
\hline & \multicolumn{4}{|c|}{ Students without Disabilities } & \multicolumn{4}{|c|}{ Students with Disabilities } \\
\hline & \multicolumn{2}{|c|}{ No } & \multicolumn{2}{|c|}{ Yes } & \multicolumn{2}{|c|}{ No } & \multicolumn{2}{|c|}{ Yes } \\
\hline & $n$ & $\%$ & $n$ & $\%$ & $n$ & $\%$ & $n$ & $\%$ \\
\hline $\begin{array}{l}\text { Deliver any papers or } \\
\text { present a poster at } \\
\text { national scholarly } \\
\text { meetings }\end{array}$ & 8,546 & 33.33 & 17,096 & 66.67 & 476 & 34.37 & 909 & 65.63 \\
\hline $\begin{array}{l}\text { Co-authored in refereed } \\
\text { journals with your } \\
\text { program faculty }\end{array}$ & 12,908 & 50.41 & 12,696 & 49.59 & 834 & 60.00 & 556 & 40.00 \\
\hline $\begin{array}{l}\text { Published as sole or first } \\
\text { author in a refereed } \\
\text { journal }\end{array}$ & 13,540 & 52.88 & 12,064 & 47.12 & 804 & 57.88 & 585 & 42.12 \\
\hline
\end{tabular}

If participants responded 'Yes' they were then asked to provide the number of occurrences.

\begin{tabular}{|c|c|c|c|c|}
\hline \multirow[t]{2}{*}{$\begin{array}{l}\text { Deliver any papers } \\
\text { or present a poster } \\
\text { at national } \\
\text { scholarly meetings }\end{array}$} & \multicolumn{2}{|c|}{$\begin{array}{l}\text { Students without } \\
\text { Disabilities } \\
(\mathrm{N}=16,538)\end{array}$} & \multicolumn{2}{|c|}{$\begin{array}{l}\text { Students with } \\
\text { Disabilities } \\
(\mathrm{N}=883)\end{array}$} \\
\hline & $n$ & $\%$ & $n$ & $\%$ \\
\hline 0 & 4,279 & 25.87 & 214 & 24.24 \\
\hline 1 & 4,436 & 26.82 & 242 & 27.52 \\
\hline 2 & 2,849 & 17.23 & 156 & 17.67 \\
\hline 3 & 1,630 & 9.86 & 65 & 7.36 \\
\hline $4+$ & 3,344 & 20.22 & 205 & 23.22 \\
\hline
\end{tabular}




\begin{tabular}{|c|c|c|c|c|}
\hline \multirow[t]{2}{*}{$\begin{array}{l}\text { Co-authored in } \\
\text { refereed journals } \\
\text { with your program } \\
\text { faculty }\end{array}$} & \multicolumn{2}{|c|}{$\begin{array}{l}\text { Students without } \\
\text { Disabilities } \\
(\mathrm{N}=12,215)\end{array}$} & \multicolumn{2}{|c|}{$\begin{array}{l}\text { Students with } \\
\text { Disabilities } \\
(\mathrm{N}=539)\end{array}$} \\
\hline & $n$ & $\%$ & $n$ & $\%$ \\
\hline 0 & 4,442 & 36.37 & 240 & 44.53 \\
\hline 1 & 3,779 & 30.94 & 161 & 29.87 \\
\hline 2 & 1,813 & 14.84 & 70 & 12.99 \\
\hline 3 & 910 & 7.45 & 24 & 4.45 \\
\hline $4+$ & 1,271 & 10.41 & 44 & 8.16 \\
\hline
\end{tabular}

\begin{tabular}{|c|c|c|c|c|}
\hline \multirow[t]{2}{*}{$\begin{array}{l}\text { Published as sole or } \\
\text { first author in a } \\
\text { refereed journal }\end{array}$} & \multicolumn{2}{|c|}{$\begin{array}{l}\text { Students without } \\
\text { Disabilities } \\
(\mathrm{N}=11,627)\end{array}$} & \multicolumn{2}{|c|}{$\begin{array}{l}\text { Students with } \\
\text { Disabilities } \\
(\mathrm{N}=567)\end{array}$} \\
\hline & $n$ & $\%$ & $n$ & $\%$ \\
\hline 0 & 4,620 & 39.74 & 252 & 44.44 \\
\hline 1 & 3,908 & 33.61 & 177 & 31.22 \\
\hline 2 & 1,655 & 14.23 & 71 & 12.52 \\
\hline 3 & 705 & 6.06 & 32 & 5.64 \\
\hline $4+$ & 739 & 6.36 & 35 & 6.17 \\
\hline
\end{tabular}


Deliver any papers or present a poster at national scholarly meetings

Co-authored in refereed journals with your program faculty

Published as sole or first author in a refereed journal
$67 \%$

$66 \%$
$50 \%$

$40 \%$

$42 \%$

No Disability $\quad$ With Disability

\section{If participants responded 'Yes' they were then asked to provide the number of occurences.}

Deliver any papers or present a poster at national scholarly meetings

$60 \%$

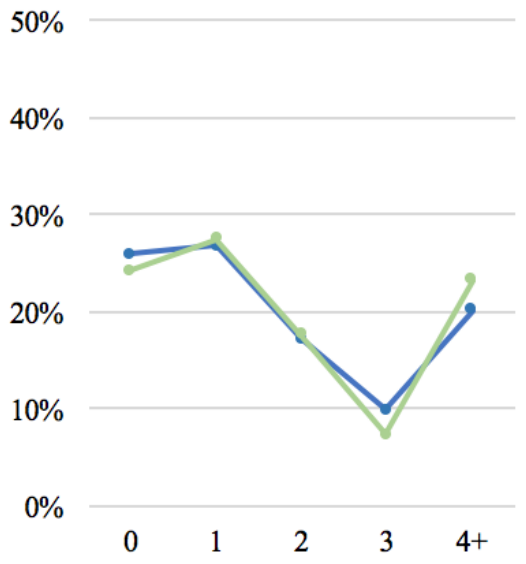

Co-authored in refereed journals with your program faculty
Published as sole or first author in a refereed journal 
SECTION 9- ADVISOR AND THESIS/DISSERTATION/RESEARCH PAPER (Long Stream Only)

Table 15

Participants' responses: Thesis/Dissertation advisors engage in a variety of mentoring activities. For each of the following statements, indicate the extent that it DESCRIBES THE BEHAVIOUR of your advisor.

\begin{tabular}{|c|c|c|c|c|c|c|c|c|c|c|}
\hline & \multicolumn{2}{|c|}{ Strongly Agree } & \multicolumn{2}{|c|}{ Agree } & \multicolumn{2}{|c|}{ Disagree } & \multicolumn{2}{|c|}{ Strongly Disagree } & \multicolumn{2}{|c|}{ \# of Respondents } \\
\hline & $\begin{array}{l}\text { No } \\
\text { Disability }\end{array}$ & $\begin{array}{l}\text { With a } \\
\text { Disability }\end{array}$ & ND & WD & ND & WD & ND & WD & ND & WD \\
\hline $\begin{array}{l}\text { My advisor was knowledgeable } \\
\text { about formal degree requirements }\end{array}$ & 57.27 & 50.61 & 35.29 & 37.17 & 5.87 & 8.99 & 1.57 & 3.24 & 25,669 & 1,391 \\
\hline $\begin{array}{l}\text { My advisor gave me constructive } \\
\text { feedback on my work }\end{array}$ & 61.75 & 56.97 & 30.66 & 32.78 & 5.62 & 6.79 & 1.97 & 3.47 & 25,567 & 1,385 \\
\hline $\begin{array}{l}\text { My advisor returned my work } \\
\text { promptly }\end{array}$ & 53.54 & 50.18 & 32.94 & 33.65 & 9.48 & 10.59 & 4.04 & 5.58 & 25,467 & 1,379 \\
\hline $\begin{array}{l}\text { My advisor promoted my } \\
\text { professional development }\end{array}$ & 53.70 & 47.14 & 33.63 & 33.38 & 9.55 & 13.90 & 3.12 & 5.58 & 25,428 & 1,381 \\
\hline $\begin{array}{l}\text { My advisor overall, performed the } \\
\text { role well }\end{array}$ & 58.90 & 53.81 & 30.68 & 30.31 & 7.60 & 11.68 & 2.81 & 4.21 & 25,482 & 1,379 \\
\hline $\begin{array}{l}\text { My advisor was available for regular } \\
\text { meetings }\end{array}$ & 59.47 & 53.70 & 30.01 & 32.17 & 7.95 & 10.22 & 2.57 & 3.91 & 25,519 & 1,380 \\
\hline
\end{tabular}




\begin{tabular}{|c|c|c|c|c|c|c|c|c|c|c|}
\hline & \multicolumn{2}{|c|}{ Strongly Agree } & \multicolumn{2}{|c|}{ Agree } & \multicolumn{2}{|c|}{ Disagree } & \multicolumn{2}{|c|}{ Strongly Disagree } & \multicolumn{2}{|c|}{ \# of Respondents } \\
\hline & $\begin{array}{c}\text { No } \\
\text { Disability }\end{array}$ & $\begin{array}{l}\text { With a } \\
\text { Disability }\end{array}$ & ND & WD & ND & WD & ND & WD & ND & WD \\
\hline $\begin{array}{l}\text { My advisor was very helpful to me } \\
\text { in preparing for written qualifying } \\
\text { exams }\end{array}$ & 41.61 & 39.21 & 41.46 & 39.45 & 12.83 & 16.30 & 4.10 & 5.04 & 23,951 & 1,270 \\
\hline $\begin{array}{l}\text { My advisor was very helpful to me } \\
\text { in preparing for the oral qualifying } \\
\text { exam }\end{array}$ & 42.26 & 39.32 & 41.40 & 38.52 & 12.37 & 16.84 & 3.97 & 5.32 & 23,645 & 1,241 \\
\hline $\begin{array}{l}\text { My advisor was very helpful to me } \\
\text { in selecting a dissertation topic }\end{array}$ & 51.63 & 47.05 & 35.57 & 34.48 & 9.68 & 14.66 & 3.13 & 3.81 & 25,032 & 1,337 \\
\hline $\begin{array}{l}\text { My advisor was very helpful to me } \\
\text { in writing a dissertation prospectus } \\
\text { or proposal }\end{array}$ & 48.62 & 45.92 & 37.63 & 35.77 & 10.60 & 13.69 & 3.15 & 4.62 & 24,443 & 1,300 \\
\hline $\begin{array}{l}\text { My advisor was very helpful to me } \\
\text { in writing the dissertation }\end{array}$ & 46.18 & 43.47 & 39.64 & 37.86 & 10.78 & 13.83 & 3.41 & 4.94 & 23,081 & 1,215 \\
\hline $\begin{array}{l}\text { My advisor was very helpful to me } \\
\text { in selecting the dissertation } \\
\text { committee }\end{array}$ & 52.22 & 47.44 & 37.59 & 38.47 & 7.64 & 11.17 & 2.55 & 2.91 & 23,605 & 1,271 \\
\hline $\begin{array}{l}\text { My advisor encouraged discussions } \\
\text { about current job market and various } \\
\text { career prospects }\end{array}$ & 35.08 & 29.64 & 34.64 & 32.02 & 21.09 & 25.40 & 9.19 & 12.93 & 23,999 & 1,299 \\
\hline
\end{tabular}

Note. With the exception of the '\# of Respondents' column, values represent percentage of respondents. 


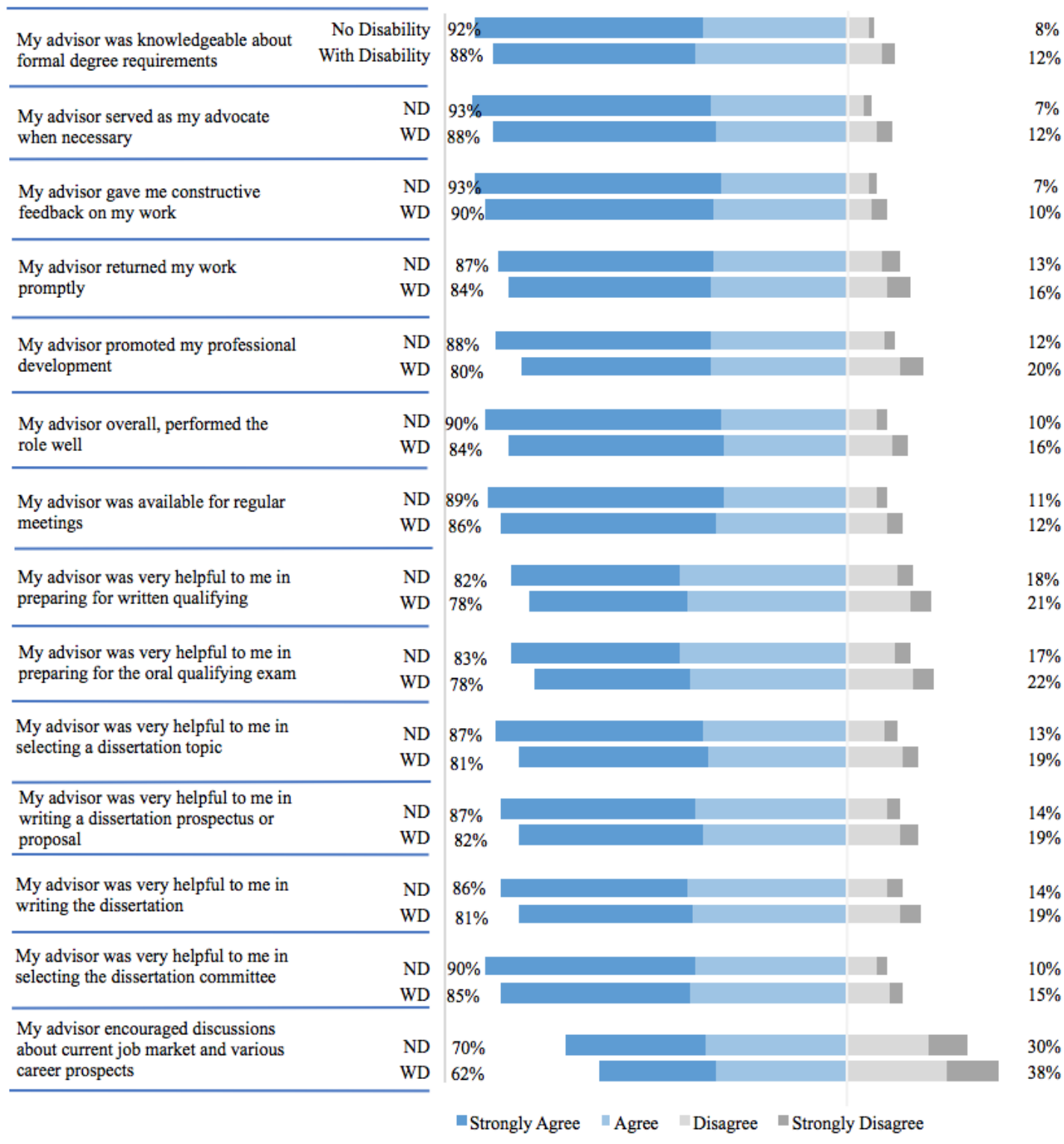


Students with Disabilities responses to: For each of the following statements, indicate the extent that it describes the behaviour of your advisor. These are arranged from most to least agreed upon statements.

My advisor gave me constructive feedback on my work.

My advisor served as my advocate when necessary.

My advisor was knowledgeable about formal degree requirements.

My advisor was available for regular meetings.

My advisor was very helpful to me in selecting the dissertation committee.

My advisor overall, performed the role well.

My advisor returned my work promptly.

My advisor was very helpful to me in selecting a dissertation topic.

\begin{tabular}{|c|c|c|c|c|}
\hline $57 \%$ & $33 \%$ & $7 \%$ & $3 \%$ \\
\hline $56 \%$ & $32 \%$ & $8 \%$ & $4 \%$ \\
\hline $51 \%$ & $37 \%$ & $9 \%$ & $3 \%$ \\
\hline $54 \%$ & $32 \%$ & $10 \%$ & $4 \%$ \\
\hline $47 \%$ & $38 \%$ & $11 \%$ & $3 \%$ \\
\hline & $34 \%$ & $30 \%$ & $12 \%$ & $4 \%$ \\
\hline & $50 \%$ & $34 \%$ & $11 \%$ & $6 \%$ \\
\hline $47 \%$ & $34 \%$ & $15 \%$ & $4 \%$ \\
\hline & $46 \%$ & $36 \%$ & $14 \%$ & $5 \%$ \\
\hline & $47 \%$ & $33 \%$ & $14 \%$ & $6 \%$ \\
\hline & $39 \%$ & $38 \%$ & $14 \%$ & $5 \%$ \\
\hline & $39 \%$ & $39 \%$ & $16 \%$ & $5 \%$ \\
\hline
\end{tabular}

My advisor was very helpful to me in preparing for the oral qualifying exam.

$30 \%$


Table 16

Participants responses: On average, how often per month do you meet or communicate with your dissertation advisor about:

\begin{tabular}{|c|c|c|c|c|c|c|c|c|}
\hline & \multicolumn{4}{|c|}{$\begin{array}{l}\text { Four or more times (at least once a } \\
\text { week) }\end{array}$} & \multicolumn{4}{|c|}{$\begin{array}{l}\text { One to three times (at least once a } \\
\text { month) }\end{array}$} \\
\hline & \multicolumn{2}{|c|}{ No Disability } & \multicolumn{2}{|c|}{$\begin{array}{l}\text { With a } \\
\text { Disability }\end{array}$} & \multicolumn{2}{|c|}{ No Disability } & \multicolumn{2}{|c|}{$\begin{array}{l}\text { With a } \\
\text { Disability }\end{array}$} \\
\hline & $n$ & $\%$ & $n$ & $\%$ & $n$ & $\%$ & $n$ & $\%$ \\
\hline $\begin{array}{l}\text { Your ongoing research } \\
\text { and results }\end{array}$ & 9,269 & 36.47 & 349 & 25.59 & 11,208 & 44.10 & 641 & 46.99 \\
\hline $\begin{array}{l}\text { Your writing of the } \\
\text { dissertation draft }\end{array}$ & 4,859 & 20.45 & 215 & 16.68 & 10,388 & 43.73 & 547 & 42.44 \\
\hline \multirow{3}{*}{$\begin{array}{l}\text { Your ongoing research and } \\
\text { results }\end{array}$} & \multicolumn{4}{|c|}{$\begin{array}{l}\text { Four or more times (at } \\
\text { least once a week) }\end{array}$} & \multicolumn{2}{|c|}{$\begin{array}{l}\text { One to three times (at } \\
\text { least once a month) }\end{array}$} & & $\begin{array}{l}\text { Less than once a } \\
\text { month }\end{array}$ \\
\hline & No Disability & \multicolumn{3}{|c|}{$36 \%$} & \multicolumn{2}{|c|}{$44 \%$} & & $19 \%$ \\
\hline & With Disability & \multicolumn{2}{|c|}{$26 \%$} & \multicolumn{3}{|c|}{$47 \%$} & \multicolumn{2}{|r|}{$27 \%$} \\
\hline \multirow{2}{*}{$\begin{array}{l}\text { Your writing of the } \\
\text { dissertation draft }\end{array}$} & No Disability & \multicolumn{2}{|c|}{$20 \%$} & \multicolumn{2}{|r|}{$44 \%$} & \multicolumn{3}{|c|}{$36 \%$} \\
\hline & With Disability & $17 \%$ & \multicolumn{3}{|c|}{$42 \%$} & \multicolumn{3}{|c|}{$41 \%$} \\
\hline
\end{tabular}


Table 17

Participants' responses: Do you have an advisory committee?

\begin{tabular}{lcccc}
\hline & \multicolumn{2}{c}{$\begin{array}{c}\text { Students without } \\
\text { Disabilities }\end{array}$} & \multicolumn{2}{c}{$\begin{array}{c}\text { Students with } \\
\text { Disabilities }\end{array}$} \\
\cline { 2 - 5 } & $n$ & $\%$ & $n$ & $\%$ \\
\hline Yes & 13,865 & 32.30 & 797 & 34.25 \\
No & 11,857 & 27.62 & 594 & 25.53 \\
Not Answered/Not Available & 17,202 & 40.08 & 936 & 40.22 \\
\hline
\end{tabular}

Table 18

Participants' responses: Do you have an advisory committee?

\begin{tabular}{lccccc}
\hline & \multicolumn{2}{c}{$\begin{array}{c}\text { Students without } \\
\text { Disabilities }\end{array}$} & \multicolumn{2}{c}{$\begin{array}{c}\text { Students with } \\
\text { Disabilities }\end{array}$} \\
\cline { 2 - 6 } & \multicolumn{2}{c}{$n$} & $\%$ & $n$ & $\%$ \\
\hline Yes & 13,865 & 53.90 & 797 & 57.30 \\
No & 11,857 & 46.10 & 594 & 42.70 \\
\hline
\end{tabular}


The following table represents responses of only those whom responded with a 'yes' to having a thesis advisory committee.

Table 19

Participants responses: Please specify with statement(s) best describe your situation (check all that apply).

\begin{tabular}{lcccc}
\hline & \multicolumn{2}{c}{$\begin{array}{c}\text { Students without } \\
\text { Disabilities }\end{array}$} & \multicolumn{2}{c}{$\begin{array}{c}\text { Students with } \\
\text { Disabilities }\end{array}$} \\
\cline { 2 - 5 } & $n$ & $\%$ & $n$ & 49.44 \\
\hline $\begin{array}{l}\text { My advisory committee expects to receive } \\
\text { from me a written progress report, at least } \\
\text { once a year }\end{array}$ & 6,572 & 47.40 & 394 & 55.58 \\
$\begin{array}{l}\text { I am expected to meet at least annually with } \\
\text { my advisory committee }\end{array}$ & 8,327 & 60.06 & 443 & \\
$\begin{array}{l}\text { I have already interacted at least once with } \\
\text { my advisory committee }\end{array}$ & 10,240 & 73.86 & 590 & 74.03 \\
\hline
\end{tabular}

If participants responded, 'I have already interacted at least once with my advisory committee' they were asked the following question.

Table 20

Participants responses: How have you interacted with your advisory committee?

\begin{tabular}{|c|c|c|c|c|}
\hline & \multicolumn{2}{|c|}{$\begin{array}{l}\text { Students without } \\
\text { Disabilities }\end{array}$} & \multicolumn{2}{|c|}{$\begin{array}{l}\text { Students with } \\
\text { Disabilities }\end{array}$} \\
\hline & $n$ & $\%$ & $n$ & $\%$ \\
\hline In a formal meeting & 8,856 & 87.10 & 483 & 82.14 \\
\hline $\begin{array}{l}\text { Through email or telephone contact (no } \\
\text { formal meeting) }\end{array}$ & 1,312 & 12.90 & 105 & 17.86 \\
\hline
\end{tabular}




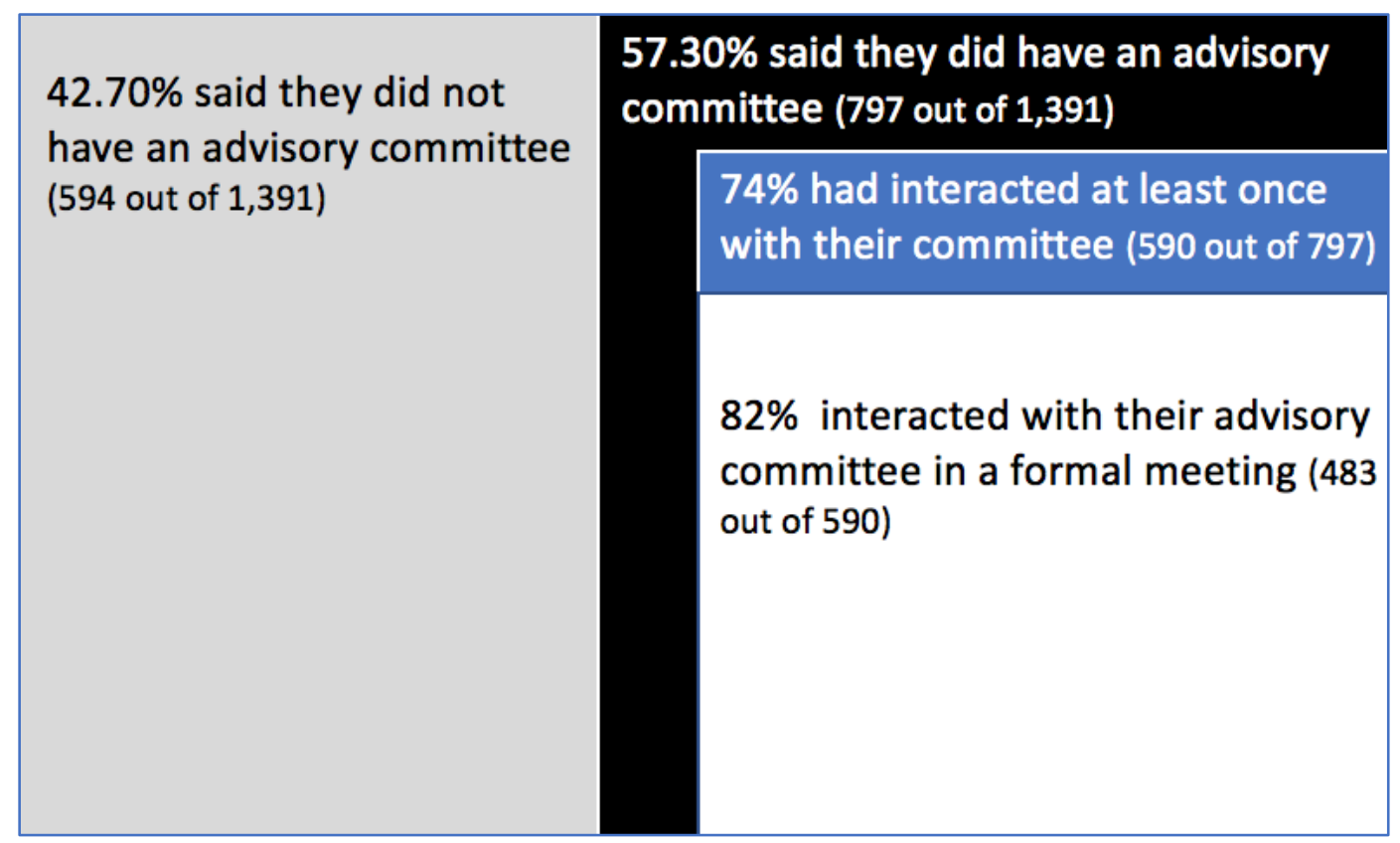

If participants responded, 'I have already interacted at least once with my advisory committee' they were asked the following question.

Table 21

Participants' responses: Up to now, I have found my advisory committee's feedback constructive and useful.

\begin{tabular}{lcccc}
\hline & \multicolumn{2}{c}{$\begin{array}{c}\text { Students without } \\
\text { Disabilities }\end{array}$} & \multicolumn{2}{c}{$\begin{array}{c}\text { Students with } \\
\text { Disabilities }\end{array}$} \\
\cline { 2 - 5 } & $n$ & $\%$ & $n$ & $\%$ \\
\hline Strongly agree & 4,401 & 43.62 & 255 & 43.66 \\
Agree & 4,877 & 48.34 & 265 & 45.38 \\
Disagree & 621 & 6.16 & 50 & 8.56 \\
Strongly disagree & 190 & 1.88 & 14 & 2.40 \\
\hline
\end{tabular}




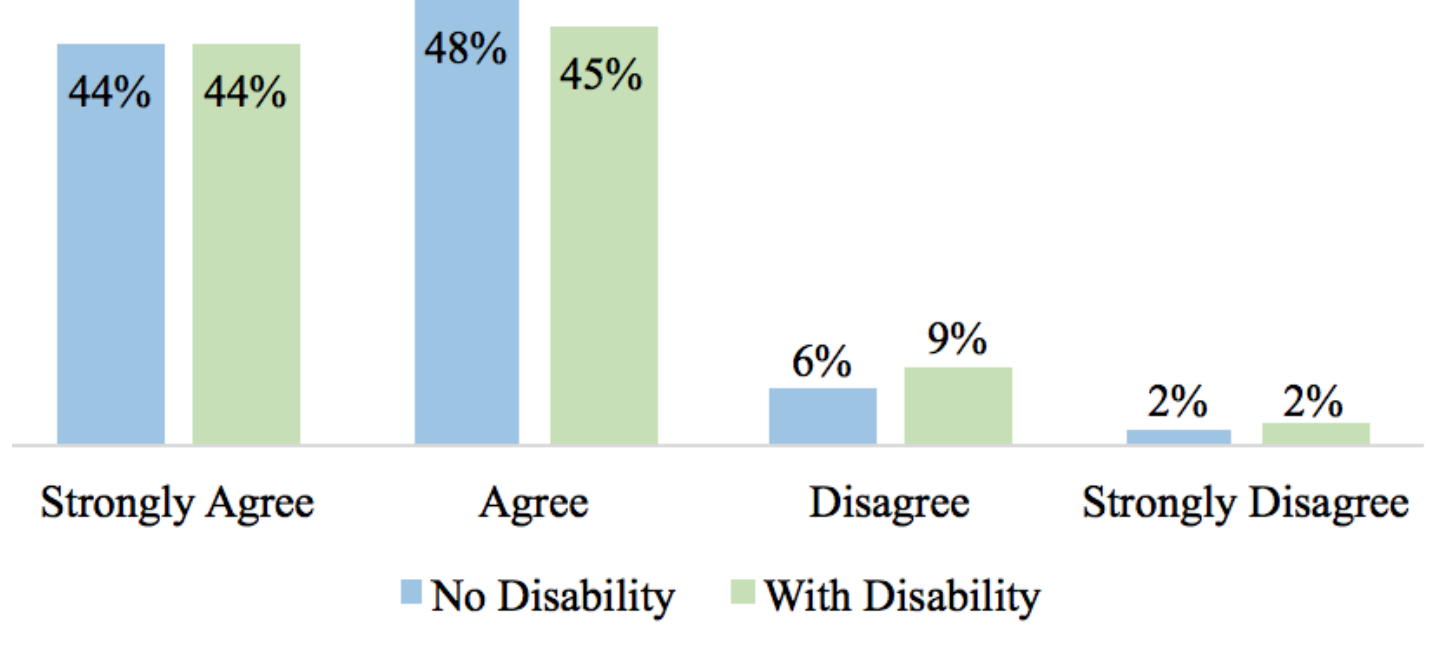




\section{SECTION 10- FINANCIAL SUPPORT}

Table 22

Participants' responses: Please check all of the following forms of support you received while you have been enrolled in your program. Please check if you received support from this source:

\begin{tabular}{|c|c|c|c|c|}
\hline & \multicolumn{2}{|c|}{$\begin{array}{c}\text { Students without } \\
\text { Disabilities } \\
(\mathrm{N}=42,924)\end{array}$} & \multicolumn{2}{|c|}{$\begin{array}{l}\text { Students with } \\
\text { Disabilities } \\
(\mathrm{N}=2,327)\end{array}$} \\
\hline & $n$ & $\%$ & $n$ & $\%$ \\
\hline $\begin{array}{l}\text { Federal Granting Council } \\
\text { Scholarship/Fellowship }\end{array}$ & 6,297 & 14.67 & 405 & 17.40 \\
\hline $\begin{array}{l}\text { Provincial Government Scholarship/ } \\
\text { Fellowship }\end{array}$ & 7,273 & 16.94 & 413 & 17.75 \\
\hline Support from a Foreign Government & 1,197 & 2.79 & 30 & 1.29 \\
\hline $\begin{array}{l}\text { External (to university) non-government } \\
\text { fellowship }\end{array}$ & 3,213 & 7.49 & 178 & 7.65 \\
\hline Provincial bursary (non-refundable) & 4,044 & 9.42 & 338 & 14.53 \\
\hline University-funded bursary & 9,044 & 21.07 & 689 & 29.61 \\
\hline University-funded fellowships & 9,136 & 21.28 & 472 & 20.28 \\
\hline Full tuition scholarships or waivers & 4,106 & 9.57 & 289 & 12.42 \\
\hline Partial tuition scholarships or waivers & 4,978 & 11.60 & 310 & 13.32 \\
\hline Graduate research assistantship & 12,050 & 28.07 & 700 & 30.08 \\
\hline Graduate teaching assistantship & 15,772 & 36.74 & 978 & 42.03 \\
\hline Other part-time research employment & 2,565 & 5.98 & 203 & 8.72 \\
\hline Other part-time teaching employment & 2,496 & 5.81 & 138 & 5.93 \\
\hline Residence Donship & 128 & 0.30 & 10 & 0.43 \\
\hline Other campus employment & 2,619 & 6.10 & 193 & 8.29 \\
\hline Off campus employment & 9,496 & 22.12 & 576 & 24.75 \\
\hline Employee benefit or employer funding & 2,973 & 6.93 & 181 & 7.78 \\
\hline Loans, savings, or family assistance & 16,579 & 38.62 & 1,180 & 55.01 \\
\hline
\end{tabular}




\section{Sources of Financial Support Used by Students with Disabilities}

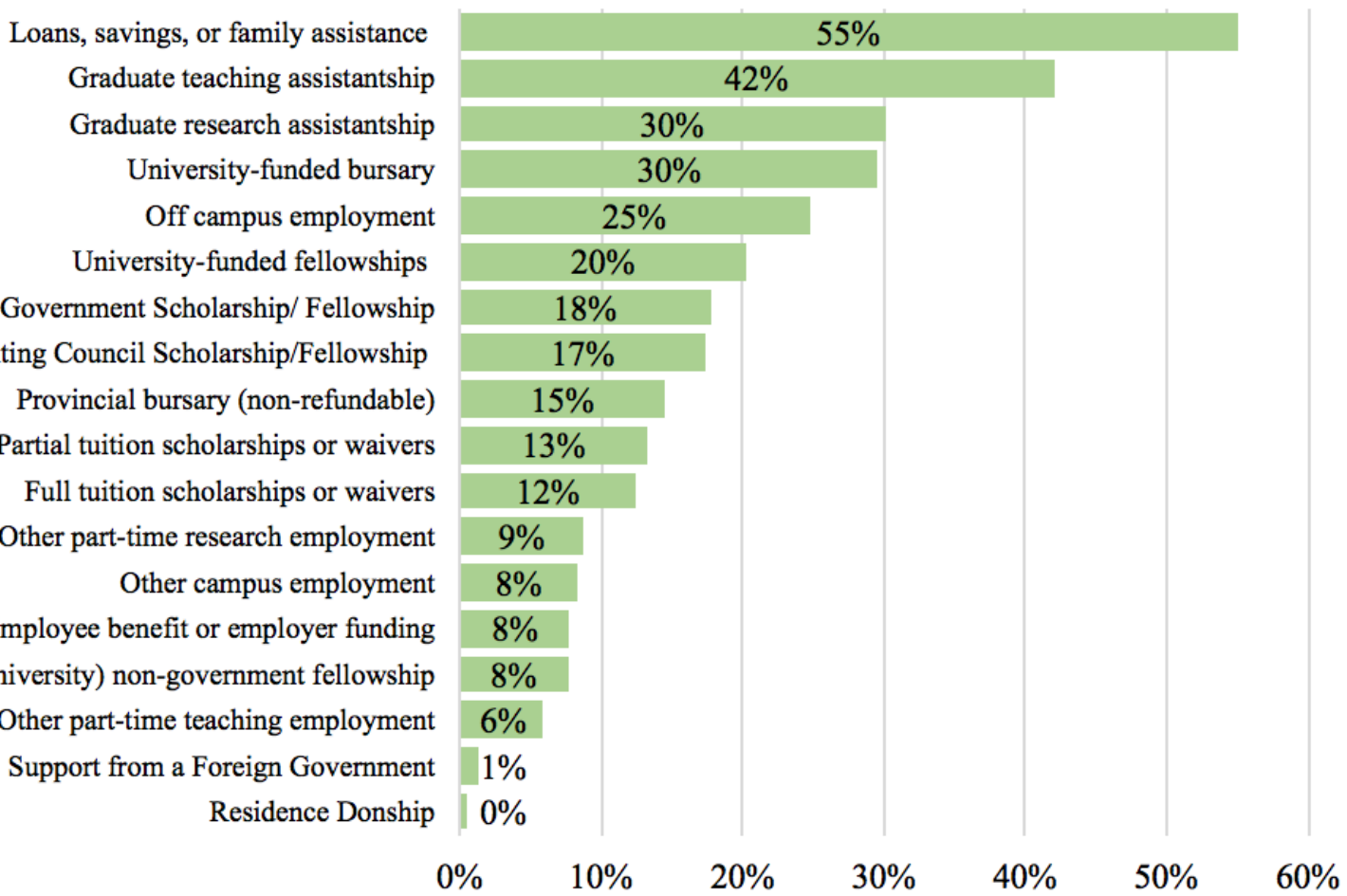

Provincial Government Scholarship/ Fellowship Federal Granting Council Scholarship/Fellowship

Provincial bursary (non-refundable)

Partial tuition scholarships or waivers

Full tuition scholarships or waivers

Other campus employment

ermployer funding

External (to university) non-government fellowship

Other part-time teaching employment

Support from a Foreign Government

$0 \%$

$10 \%$

$20 \%$

$30 \%$

$40 \%$

$50 \%$

$60 \%$ 
Leading sources of financial support for students with and without disabilities are similar, with one exception.

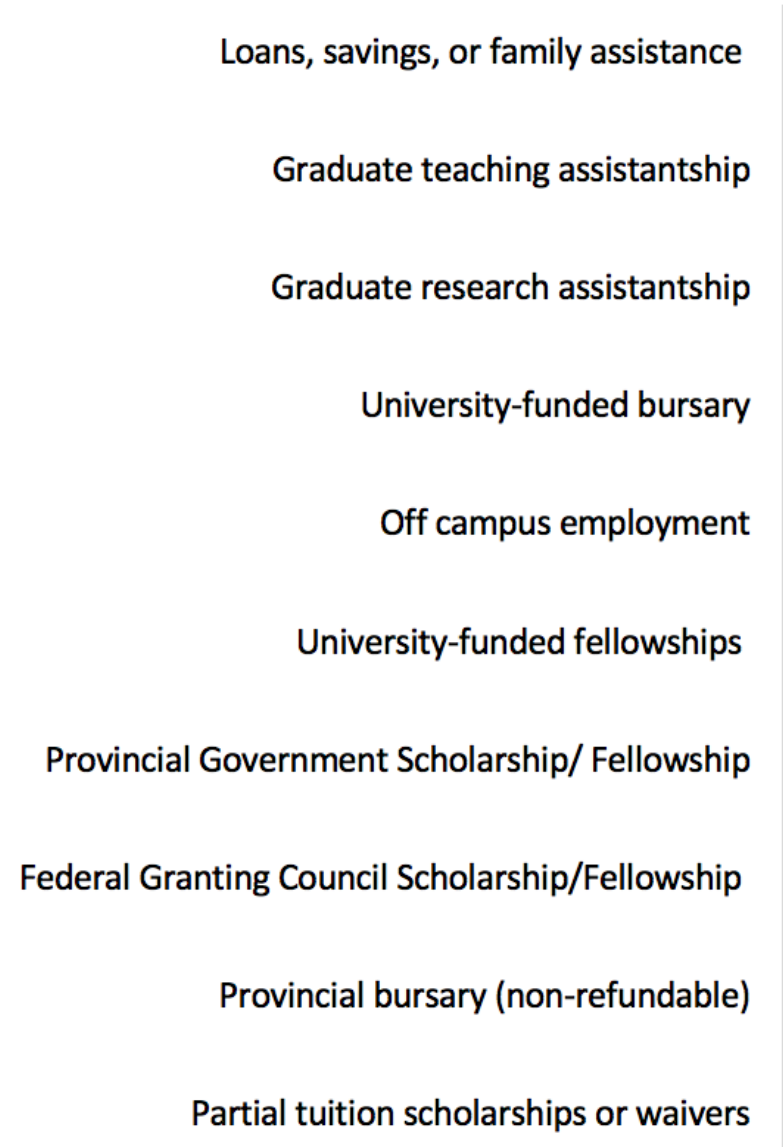

Students without Students with

Disabilities

Disabilities

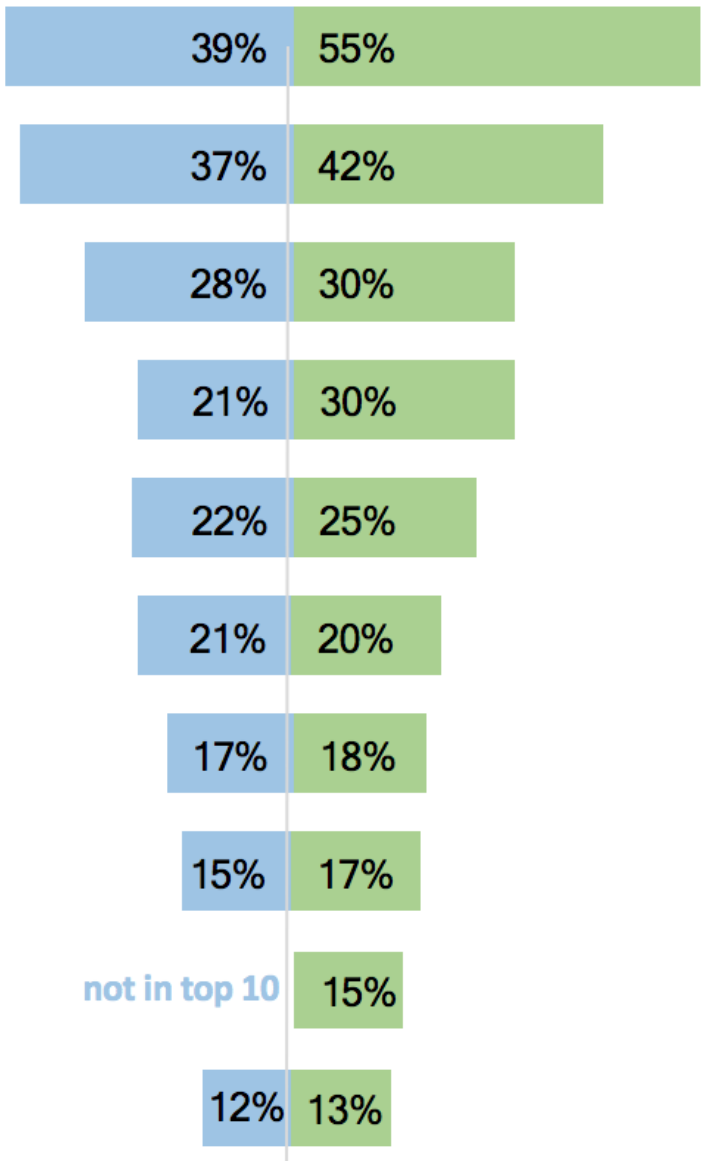


Table 23

Participants responses: Please estimate the amount of undergraduate educational debt, if any, you will have to repay when you have completed your graduate degree here.

\begin{tabular}{lcccc}
\hline & \multicolumn{2}{c}{$\begin{array}{c}\text { Students without } \\
\text { Disabilities }\end{array}$} & \multicolumn{2}{c}{$\begin{array}{c}\text { Students with } \\
\text { Disabilities }\end{array}$} \\
\cline { 2 - 5 } & $n$ & $\%$ & $n$ & $\%$ \\
\hline$\$ 0$ & 27,344 & 65.85 & 1,242 & 54.02 \\
$\$ 1-\$ 9,999$ & 3,433 & 8.27 & 183 & 7.96 \\
$\$ 10,000-19,999$ & 3,677 & 8.86 & 212 & 9.22 \\
$\$ 20,000-29,999$ & 2,859 & 6.89 & 204 & 8.87 \\
$\$ 30,000-\$ 39,999$ & 1,777 & 4.28 & 176 & 7.66 \\
$\$ 40,000-\$ 49,999$ & 1,087 & 2.62 & 120 & 5.22 \\
$\$ 50,000-\$ 59,999$ & 626 & 1.51 & 79 & 3.44 \\
$\$ 60,000-\$ 69,999$ & 275 & 0.66 & 31 & 1.35 \\
$\$ 70,000-\$ 79,999$ & 146 & 0.35 & 15 & 0.65 \\
$\$ 80,000$ or more & 299 & 0.72 & 37 & 1.61 \\
\hline
\end{tabular}

Table 24

Participants responses: Please estimate the amount of graduate educational debt, if any, you will have to repay when you have completed your graduate degree here.

\begin{tabular}{lcccc}
\hline & \multicolumn{2}{c}{$\begin{array}{c}\text { Students without } \\
\text { Disabilities }\end{array}$} & \multicolumn{2}{c}{$\begin{array}{c}\text { Students with } \\
\text { Disabilities }\end{array}$} \\
\cline { 2 - 5 } & $n$ & $\%$ & $n$ & $\%$ \\
\hline$\$ 0$ & 20,475 & 49.18 & 825 & 36.28 \\
$\$ 1-\$ 9,999$ & 7,244 & 17.40 & 440 & 19.35 \\
$\$ 10,000-19,999$ & 5,734 & 13.77 & 384 & 16.89 \\
$\$ 20,000-29,999$ & 3,560 & 8.55 & 245 & 10.77 \\
$\$ 30,000-\$ 39,999$ & 1,767 & 4.24 & 144 & 6.33 \\
$\$ 40,000-\$ 49,999$ & 1,072 & 2.58 & 93 & 4.09 \\
$\$ 50,000-\$ 59,999$ & 637 & 1.53 & 54 & 2.37 \\
$\$ 60,000-\$ 69,999$ & 385 & 0.92 & 26 & 1.14 \\
$\$ 70,000-\$ 79,999$ & 215 & 0.52 & 17 & 0.75 \\
$\$ 80,000$ or more & 540 & 1.30 & 46 & 2.02 \\
\hline
\end{tabular}




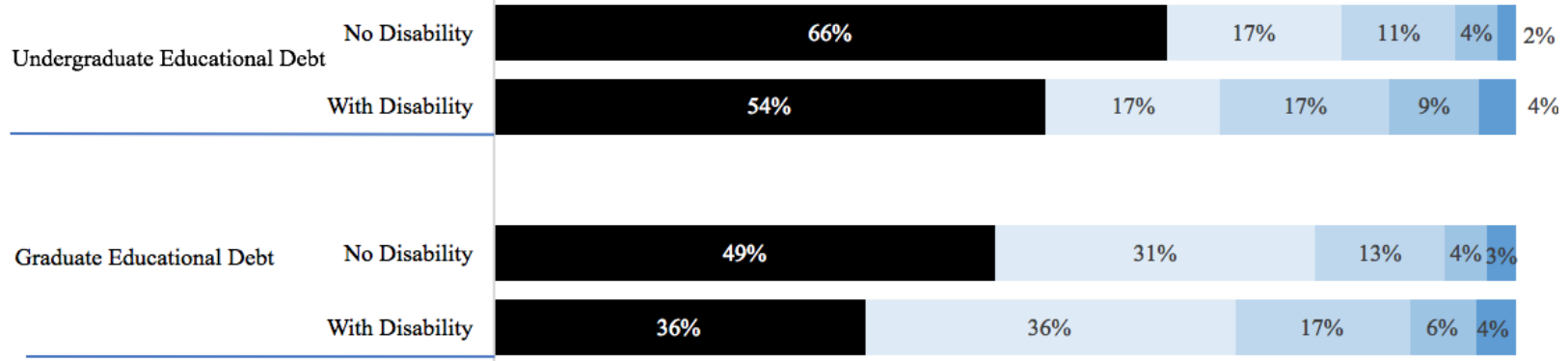

- $\$ 0 \$ 1-19,999=\$ 20,000-39,999 \backsim \$ 40,000-59,999 \backsim \$ 60,000$ or more 


\section{SECTION 11- UNIVERSITY RESOURCES AND STUDENT LIFE}

Table 25

Participants' Responses: Please rate the following university resources based on the quality you have experienced while using them. Please answer regarding your most recent year's experience in the graduate school at this university.

\begin{tabular}{|c|c|c|c|c|c|c|c|c|c|c|c|c|c|c|}
\hline & \multicolumn{2}{|c|}{ Excellent } & \multicolumn{2}{|c|}{ Very Good } & \multicolumn{2}{|c|}{ Good } & \multicolumn{2}{|c|}{ Fair } & \multicolumn{2}{|c|}{ Poor } & \multicolumn{2}{|c|}{$\begin{array}{c}\text { Did not } \\
\text { Participate }\end{array}$} & \multicolumn{2}{|c|}{$\begin{array}{c}\text { Not } \\
\text { Applicable }\end{array}$} \\
\hline & $\begin{array}{c}\text { No } \\
\text { Disability }^{\mathrm{a}}\end{array}$ & $\begin{array}{c}\text { With a } \\
\text { Disability }\end{array}$ & ND & WD & ND & WD & ND & WD & ND & WD & ND & WD & ND & WD \\
\hline Library facilities & 32.59 & 30.29 & 34.30 & 31.20 & 19.54 & 22.47 & 4.57 & 6.70 & 1.59 & 3.33 & 5.51 & 4.67 & 1.88 & 1.34 \\
\hline $\begin{array}{l}\text { Graduate student } \\
\text { work/study space }\end{array}$ & 16.63 & 13.61 & 19.57 & 13.83 & 18.82 & 18.27 & 11.40 & 14.13 & 10.53 & 18.27 & 15.03 & 12.55 & 8.01 & 9.34 \\
\hline Research laboratories & 12.37 & 7.48 & 15.64 & 9.60 & 14.29 & 12.47 & 6.46 & 5.87 & 2.88 & 4.35 & 22.93 & 22.25 & 25.43 & 37.98 \\
\hline Health care services & 10.93 & 11.34 & 16.36 & 16.33 & 17.91 & 18.40 & 7.70 & 10.24 & 3.40 & 5.91 & 31.52 & 26.13 & 12.17 & 11.65 \\
\hline Child care services & 2.43 & 1.06 & 2.72 & 1.15 & 3.04 & 1.64 & 1.74 & 1.28 & 1.78 & 2.97 & 48.55 & 42.63 & 39.74 & 49.27 \\
\hline Financial aid office & 6.15 & 4.88 & 10.32 & 9.71 & 14.66 & 15.24 & 9.02 & 11.63 & 5.07 & 9.58 & 37.98 & 33.28 & 16.80 & 15.68 \\
\hline Career services & 5.66 & 2.79 & 8.79 & 6.33 & 12.29 & 11.70 & 7.68 & 8.51 & 4.86 & 8.08 & 46.25 & 45.96 & 14.46 & 16.63 \\
\hline $\begin{array}{l}\text { Student counselling \& } \\
\text { resource center }\end{array}$ & 6.41 & 8.44 & 8.87 & 10.31 & 10.60 & 11.15 & 5.54 & 8.92 & 3.30 & 8.61 & 50.33 & 39.60 & 14.95 & 12.98 \\
\hline Athletic facilities & 15.03 & 9.52 & 20.78 & 15.59 & 17.26 & 15.54 & 6.33 & 6.95 & 3.26 & 5.36 & 28.01 & 34.85 & 9.34 & 12.18 \\
\hline $\begin{array}{l}\text { Services to international } \\
\text { students attending this } \\
\text { university }\end{array}$ & 6.30 & 2.52 & 8.15 & 2.96 & 8.31 & 2.96 & 4.31 & 2.70 & 2.63 & 2.09 & 34.05 & 33.72 & 36.25 & 52.05 \\
\hline
\end{tabular}




\begin{tabular}{|c|c|c|c|c|c|c|c|c|c|c|c|c|c|c|}
\hline & \multicolumn{2}{|c|}{ Excellent } & \multicolumn{2}{|c|}{ Very Good } & \multicolumn{2}{|c|}{ Good } & \multicolumn{2}{|c|}{ Fair } & \multicolumn{2}{|c|}{ Poor } & \multicolumn{2}{|c|}{$\begin{array}{l}\text { Did not } \\
\text { Participate }\end{array}$} & \multicolumn{2}{|c|}{$\begin{array}{c}\text { Not } \\
\text { Applicable }\end{array}$} \\
\hline & $\begin{array}{c}\text { No } \\
\text { Disability }^{\mathrm{a}}\end{array}$ & $\begin{array}{l}\text { With a } \\
\text { Disability }\end{array}$ & ND & WD & ND & WD & ND & WD & ND & WD & ND & WD & ND & WD \\
\hline $\begin{array}{l}\text { Services to students } \\
\text { attending this university } \\
\text { studying abroad (or } \\
\text { preparing to) }\end{array}$ & 3.42 & 1.57 & 4.14 & 2.05 & 4.76 & 2.57 & 2.49 & 2.26 & 1.44 & 1.96 & 42.95 & 39.34 & 40.79 & 50.26 \\
\hline Housing assistance & 3.15 & 1.94 & 4.29 & 2.65 & 5.89 & 3.27 & 4.35 & 2.96 & 4.66 & 5.69 & 47.06 & 44.04 & 30.61 & 39.45 \\
\hline Ombudsperson's office & 2.36 & 1.88 & 2.91 & 2.09 & 3.77 & 2.01 & 2.01 & 1.96 & 1.19 & 2.79 & 55.96 & 53.55 & 31.80 & 35.72 \\
\hline $\begin{array}{l}\text { Public/Campus } \\
\text { transportation service }\end{array}$ & 13.30 & 9.62 & 18.47 & 14.98 & 19.00 & 18.84 & 9.51 & 12.06 & 5.32 & 8.02 & 21.95 & 21.41 & 12.45 & 15.07 \\
\hline Food services & 6.65 & 4.69 & 14.60 & 12.07 & 27.08 & 25.15 & 19.24 & 22.94 & 11.43 & 15.78 & 13.05 & 12.29 & 7.95 & 7.07 \\
\hline University bookstore & 11.02 & 8.22 & 22.74 & 19.58 & 31.78 & 30.98 & 13.67 & 18.34 & 3.78 & 7.34 & 11.54 & 10.08 & 5.47 & 5.48 \\
\hline $\begin{array}{l}\text { Student government } \\
\text { office }\end{array}$ & 5.53 & 3.89 & 10.21 & 7.47 & 14.10 & 12.36 & 6.12 & 7.90 & 2.91 & 4.93 & 43.26 & 44.98 & 17.87 & 18.47 \\
\hline Registrarial processes & 11.84 & 8.47 & 23.58 & 19.95 & 31.17 & 30.60 & 13.25 & 18.29 & 4.97 & 8.86 & 9.76 & 8.42 & 5.43 & 5.41 \\
\hline $\begin{array}{l}\text { Information technology } \\
\text { services }\end{array}$ & 12.08 & 10.28 & 23.43 & 20.04 & 27.55 & 26.32 & 10.34 & 14.77 & 3.70 & 6.93 & 16.11 & 15.12 & 6.80 & 6.54 \\
\hline $\begin{array}{l}\text { Disability/Access } \\
\text { services office }\end{array}$ & 3.51 & 15.09 & 3.80 & 13.40 & 3.71 & 12.44 & 1.26 & 8.39 & 0.52 & 7.61 & 45.31 & 25.84 & 41.90 & 17.22 \\
\hline
\end{tabular}

Note. Values represent percentage of respondents.

$\mathrm{N}^{\mathrm{a}}=41,538-42,692 . \mathrm{N}^{\mathrm{b}}=2,256-2,314$. 


\begin{tabular}{ll} 
Library facilities & N \\
\hline $\begin{array}{l}\text { Graduate student work/study } \\
\text { space }\end{array}$ & N \\
\hline Research laboratories & N \\
\hline Health care services & W \\
\hline Child care services & N \\
\hline Financial aid office & W \\
\hline Career services & N \\
\hline Student counselling \& \\
resource center
\end{tabular}

\begin{tabular}{ll}
\hline $\begin{array}{l}\text { Public/Campus transportation } \\
\text { service }\end{array}$ & N \\
Food services & N \\
& W \\
\hline University bookstore & N \\
\hline Student government office & N \\
\hline Registrarial processes & N \\
\hline $\begin{array}{l}\text { Information technology services } \\
\text { W }\end{array}$ & N \\
\hline $\begin{array}{l}\text { Disability/Access services } \\
\text { office }\end{array}$ & N \\
\hline
\end{tabular}

Excellent Very Good Good Poor

$33 \% \quad 34 \% \quad 20 \% \quad 5 \%$

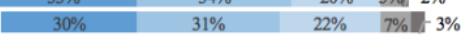

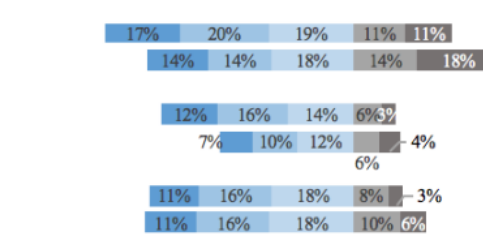

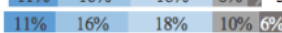

All values are $3 \%$ or less "

All values are $3 \%$ or less III

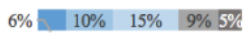

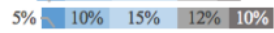

\begin{tabular}{lllll}
$6 \%$ & $9 \%$ & $12 \%$ & $8 \% 5 \%$ \\
\hline
\end{tabular}

$3 \% \square 6 \% \quad 12 \% \quad 9 \% \quad 8 \%$

$6 \% \quad 9 \% \quad 11 \% \quad 6 \%$

\begin{tabular}{l|l|l|l|l|l|l|l}
\hline 8 & $10 \%$ & $11 \%$ & $9 \%$ & $9 \%$
\end{tabular}

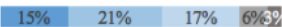

$10 \% \quad 16 \% \quad 16 \% \quad 7 \% 5 \%$

All values are $4 \%$ or less

All values are $4 \%$ or less

All values are $3 \%$ or less

All values are $3 \%$ or less

All remaining values are $3 \%$ or less

All remaining values are $3 \%$ or less $\quad 6 \%$

All values are $3 \%$ or less

All values are $3 \%$ or less

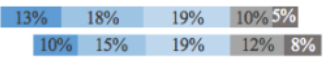

\begin{tabular}{|l|l|l|l|l|}
\hline $7 \%$ & $15 \%$ & $27 \%$ & $19 \%$ & $11 \%$ \\
\hline
\end{tabular}

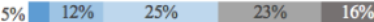

\begin{tabular}{|l|l|l|l|l|}
\hline $11 \%$ & $23 \%$ & $32 \%$ & $14 \%$ & $4 \%$ \\
\hline
\end{tabular}

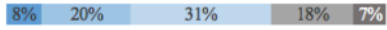

$6 \% \quad 10 \% \quad 14 \% \quad 6 \%-3 \%$

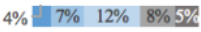

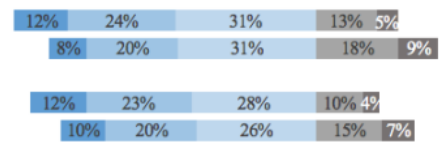

All values are $4 \%$ or less

미

\begin{tabular}{l|l|l|l|l|l|l|}
$15 \%$ & $13 \%$ & $12 \%$ & $8 \%$ & $8 \%$
\end{tabular}
Did not

Participate Not Applicable

$8 \%-2 \%$

$3 \%$ | $1 \%$

$10 \% 6 \%$

$12 \% \quad 10 \%$

$13 \% \quad 19 \%$

$25 \% \quad 47 \%$

$20 \% \quad 8 \%$

$28 \% \quad 13 \%$

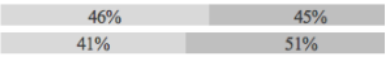

\begin{tabular}{l|l|}
\hline $37 \%$ & $14 \%$ \\
\hline
\end{tabular}

\begin{tabular}{l|l}
$31 \%$ & $16 \%$ \\
\hline
\end{tabular}

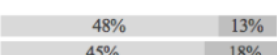

\begin{tabular}{ll}
$45 \%$ & $18 \%$ \\
\hline
\end{tabular}

$40 \% \quad 9 \%$

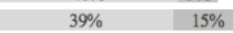

$27 \% \quad 6 \%$

$39 \% \quad 15 \%$
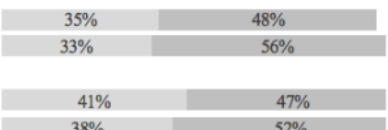

\begin{tabular}{|l|l|}
\hline $47 \%$ & $35 \%$ \\
\hline
\end{tabular}
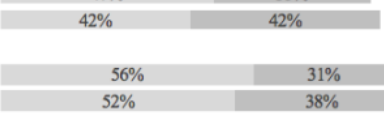

$23 \% \quad 10 \%$

$20 \% \quad 17 \%$

$14 \% \quad 5 \%$

$11 \% 7 \%$

$14 \% \quad 5 \%$

$8 \% 6 \%$
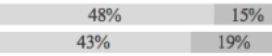

$10 \% 5 \%$

$8 \% 6 \%$

$16 \% \quad 4 \%$

$14 \% \quad 7 \%$

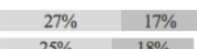


Table 26

Participants responses: In some universities, resources are offered in multiple locations. To distinguish between resources or services that are offered by a "local office", for example based in a school, department or faculty, as opposed to a "central office" location offering their services campus-wide, please indicate if your rating applies to services received from a "local office" or from a "central office", or applies to both. Please answer regarding your most recent year's experience in the graduate school at this university. (Data collected only if item was ranked in previous question).

\begin{tabular}{|c|c|c|c|c|c|c|c|c|c|c|c|c|}
\hline & \multicolumn{4}{|c|}{ Local office } & \multicolumn{4}{|c|}{ Central Office } & \multicolumn{4}{|c|}{ Both } \\
\hline & \multicolumn{2}{|c|}{ No Disability } & \multicolumn{2}{|c|}{ With a Disability } & \multicolumn{2}{|c|}{ No Disability } & \multicolumn{2}{|c|}{ With a Disability } & \multicolumn{2}{|c|}{ No Disability } & \multicolumn{2}{|c|}{ With a Disability } \\
\hline & $n$ & $\%$ & $n$ & $\%$ & $n$ & $\%$ & $n$ & $\%$ & $n$ & $\%$ & $n$ & $\%$ \\
\hline Library facilities & 9,373 & 24.78 & 398 & 19.07 & 17,288 & 45.71 & 1,025 & 49.11 & 11,158 & 29.50 & 664 & 31.82 \\
\hline $\begin{array}{l}\text { Graduate student } \\
\text { work/study space }\end{array}$ & 21,374 & 69.10 & 1,172 & 68.82 & 4,633 & 14.98 & 262 & 15.38 & 4,993 & 15.92 & 269 & 15.80 \\
\hline Research laboratories & 15,097 & 72.72 & 617 & 71.25 & 2,633 & 12.68 & 130 & 15.01 & 3,030 & 14.60 & 119 & 13.74 \\
\hline Health care services & 4,060 & 18.19 & 184 & 13.63 & 35.57 & 68.40 & 1,015 & 75.19 & 2,992 & 13.41 & 151 & 11.19 \\
\hline Child care services & 1,287 & 30.11 & 36 & 22.22 & 2,086 & 48.80 & 99 & 61.11 & 902 & 21.10 & 27 & 16.67 \\
\hline Financial aid office & 4,068 & 22.74 & 199 & 18.11 & 10,848 & 60.63 & 746 & 67.88 & 2,977 & 16.64 & 154 & 14.01 \\
\hline Career services & 4,689 & 30.45 & 207 & 25.52 & 7,732 & 50.21 & 460 & 56.72 & 2,979 & 19.34 & 144 & 17.76 \\
\hline $\begin{array}{l}\text { Student counselling \& } \\
\text { resource center }\end{array}$ & 3,717 & 27.52 & 191 & 18.76 & 7,282 & 53.91 & 693 & 68.07 & 2,509 & 18.57 & 134 & 13.16 \\
\hline Athletic facilities & 4,292 & 17.23 & 178 & 15.44 & 17,232 & 69.17 & 832 & 72.16 & 3,388 & 13.60 & 143 & 12.40 \\
\hline $\begin{array}{l}\text { Services to international } \\
\text { students attending this } \\
\text { university }\end{array}$ & 2,780 & 23.96 & 59 & 20.21 & 6,387 & 55.04 & 175 & 59.93 & 2,438 & 21.01 & 58 & 19.86 \\
\hline
\end{tabular}




\begin{tabular}{|c|c|c|c|c|c|c|c|c|c|c|c|c|}
\hline & \multicolumn{4}{|c|}{ Local office } & \multicolumn{4}{|c|}{ Central Office } & \multicolumn{4}{|c|}{ Both } \\
\hline & \multicolumn{2}{|c|}{ No Disability } & \multicolumn{2}{|c|}{ With a Disability } & \multicolumn{2}{|c|}{ No Disability } & \multicolumn{2}{|c|}{ With a Disability } & \multicolumn{2}{|c|}{ No Disability } & \multicolumn{2}{|c|}{ With a Disability } \\
\hline & $n$ & $\%$ & $n$ & $\%$ & $n$ & $\%$ & $n$ & $\%$ & $n$ & $\%$ & $n$ & $\%$ \\
\hline $\begin{array}{l}\text { Services to students } \\
\text { attending this university } \\
\text { studying abroad (or } \\
\text { preparing to) }\end{array}$ & 1,759 & 28.41 & 53 & 24.20 & 2,995 & 48.38 & 123 & 56.16 & 1,437 & 23.21 & 43 & 19.63 \\
\hline Housing assistance & 1,994 & 23.46 & 55 & 16.03 & 5,037 & 59.27 & 238 & 69.39 & 1,467 & 17.26 & 50 & 14.58 \\
\hline Ombudsperson's office & 1,321 & 28.82 & 43 & 18.61 & 2,371 & 51.72 & 160 & 69.26 & 892 & 19.46 & 28 & 12.12 \\
\hline $\begin{array}{l}\text { Public/Campus } \\
\text { transportation service }\end{array}$ & 3,917 & 15.20 & 177 & 12.91 & 16,219 & 62.93 & 936 & 68.27 & 5,639 & 21.88 & 258 & 18.82 \\
\hline Food services & 7,749 & 24.56 & 362 & 20.46 & 15,086 & 47.81 & 943 & 53.31 & 8,721 & 27.64 & 464 & 26.23 \\
\hline University bookstore & 6,648 & 20.02 & 317 & 17.15 & 21,537 & 64.85 & 1,294 & 70.02 & 5,025 & 15.13 & 237 & 12.82 \\
\hline Student government office & 5,410 & 35.23 & 227 & 28.55 & 6,198 & 40.36 & 395 & 49.69 & 3,749 & 24.41 & 173 & 21.76 \\
\hline Registrarial processes & 8,506 & 25.16 & 412 & 22.03 & 17,267 & 51.08 & 993 & 53.10 & 8,034 & 23.76 & 465 & 24.87 \\
\hline $\begin{array}{l}\text { Information technology } \\
\text { services }\end{array}$ & 8,529 & 27.83 & 405 & 23.78 & 13,687 & 44.66 & 838 & 49.21 & 8,431 & 27.51 & 460 & 27.01 \\
\hline $\begin{array}{l}\text { Disability/Access services } \\
\text { office }\end{array}$ & 1,331 & 27.64 & 201 & 16.16 & 2,050 & 42.58 & 859 & 69.05 & 1,434 & 29.78 & 184 & 14.79 \\
\hline
\end{tabular}




\begin{tabular}{|c|c|c|c|c|}
\hline & & ocal Office & Central Office & Both \\
\hline Library facilities & $\begin{array}{r}\text { No Disability } \\
\text { With Disability }\end{array}$ & $\begin{array}{l}25 \% \\
19 \%\end{array}$ & $\begin{array}{l}46 \% \\
49 \%\end{array}$ & $\begin{array}{l}30 \% \\
32 \%\end{array}$ \\
\hline $\begin{array}{l}\text { Graduate student work/study } \\
\text { space }\end{array}$ & $\begin{array}{l}\text { ND } \\
\text { WD }\end{array}$ & $\begin{array}{l}69 \% \\
69 \%\end{array}$ & $\begin{array}{l}15 \% \\
15 \%\end{array}$ & $\begin{array}{l}16 \% \\
16 \%\end{array}$ \\
\hline Research laboratories & $\begin{array}{l}\text { ND } \\
\text { WD }\end{array}$ & $\begin{array}{l}73 \% \\
71 \%\end{array}$ & $\begin{array}{l}13 \% \\
15 \%\end{array}$ & $\begin{array}{l}15 \% \\
14 \%\end{array}$ \\
\hline Health care services & $\begin{array}{l}\text { ND } \\
\text { WD }\end{array}$ & $\begin{array}{l}18 \% \\
14 \%\end{array}$ & $\begin{array}{l}68 \% \\
75 \%\end{array}$ & $\begin{array}{l}13 \% \\
11 \%\end{array}$ \\
\hline Child care services & $\begin{array}{l}\text { ND } \\
\text { WD }\end{array}$ & $\begin{array}{l}30 \% \\
22 \%\end{array}$ & $\begin{array}{l}49 \% \\
61 \%\end{array}$ & $\begin{array}{l}21 \% \\
17 \%\end{array}$ \\
\hline Financial aid office & $\begin{array}{l}\text { ND } \\
\text { WD }\end{array}$ & $\begin{array}{l}23 \% \\
18 \%\end{array}$ & $\begin{array}{l}61 \% \\
68 \%\end{array}$ & $\begin{array}{l}17 \% \\
14 \%\end{array}$ \\
\hline Career services & $\begin{array}{l}\text { ND } \\
\text { WD }\end{array}$ & $\frac{30 \%}{26 \%}$ & $\begin{array}{l}50 \% \\
57 \%\end{array}$ & $\begin{array}{l}19 \% \\
18 \%\end{array}$ \\
\hline $\begin{array}{l}\text { Student counselling \& } \\
\text { resource center }\end{array}$ & $\begin{array}{l}\text { ND } \\
\text { WD }\end{array}$ & $\begin{array}{l}28 \% \\
19 \%\end{array}$ & $54 \%$ & $\begin{array}{l}19 \% \\
13 \%\end{array}$ \\
\hline Athletic facilities & $\begin{array}{l}\text { ND } \\
\text { WD }\end{array}$ & $\begin{array}{l}17 \% \\
15 \%\end{array}$ & $\begin{array}{l}69 \% \\
72 \%\end{array}$ & $\begin{array}{l}14 \% \\
12 \%\end{array}$ \\
\hline $\begin{array}{l}\text { Services to international } \\
\text { students attending this }\end{array}$ & $\begin{array}{l}\text { ND } \\
\text { WD }\end{array}$ & $\begin{array}{l}24 \% \\
20 \%\end{array}$ & $\begin{array}{l}55 \% \\
60 \%\end{array}$ & $\begin{array}{l}21 \% \\
20 \%\end{array}$ \\
\hline $\begin{array}{l}\text { Services to students attending } \\
\text { university studying abroad }\end{array}$ & $\begin{array}{l}\text { ND } \\
\text { WD }\end{array}$ & $\begin{array}{l}28 \% \\
24 \%\end{array}$ & $\begin{array}{l}48 \% \\
56 \%\end{array}$ & $\begin{array}{l}23 \% \\
20 \%\end{array}$ \\
\hline Housing assistance & $\begin{array}{l}\text { ND } \\
\text { WD }\end{array}$ & $\begin{array}{l}23 \% \\
16 \%\end{array}$ & $\begin{array}{l}59 \% \\
69 \%\end{array}$ & $\begin{array}{l}17 \% \\
15 \%\end{array}$ \\
\hline Ombudsperson's office & $\begin{array}{l}\text { ND } \\
\text { WD }\end{array}$ & $\begin{array}{l}29 \% \\
19 \%\end{array}$ & $\begin{array}{l}52 \% \\
69 \%\end{array}$ & $\begin{array}{l}19 \% \\
12 \%\end{array}$ \\
\hline $\begin{array}{l}\text { Public/Campus transportation } \\
\text { service }\end{array}$ & $\begin{array}{l}\text { ND } \\
\text { WD }\end{array}$ & $\begin{array}{l}15 \% \\
13 \%\end{array}$ & $\begin{array}{l}63 \% \\
68 \%\end{array}$ & $\begin{array}{l}22 \% \\
19 \%\end{array}$ \\
\hline Food services & $\begin{array}{l}\text { ND } \\
\text { WD }\end{array}$ & $\begin{array}{l}25 \% \\
20 \%\end{array}$ & $\begin{array}{l}48 \% \\
53 \%\end{array}$ & $\begin{array}{l}28 \% \\
26 \%\end{array}$ \\
\hline University bookstore & $\begin{array}{l}\text { ND } \\
\text { WD }\end{array}$ & $\begin{array}{l}20 \% \\
17 \%\end{array}$ & $\begin{array}{l}65 \% \\
70 \%\end{array}$ & $\begin{array}{l}15 \% \\
13 \%\end{array}$ \\
\hline Student government office & $\begin{array}{l}\text { ND } \\
\text { WD }\end{array}$ & $\begin{array}{c}35 \% \\
29 \%\end{array}$ & $\begin{array}{l}40 \% \\
50 \%\end{array}$ & $\begin{array}{l}24 \% \\
22 \%\end{array}$ \\
\hline Registrarial processes & $\begin{array}{l}\text { ND } \\
\text { WD }\end{array}$ & $\frac{25 \%}{22 \%}$ & $51 \%$ & $\begin{array}{l}24 \% \\
25 \%\end{array}$ \\
\hline $\begin{array}{l}\text { Information technology } \\
\text { services }\end{array}$ & $\begin{array}{l}\text { ND } \\
\text { WD }\end{array}$ & $28 \%$ & $45 \%$ & $\begin{array}{l}28 \% \\
27 \%\end{array}$ \\
\hline $\begin{array}{l}\text { Disability/Access services } \\
\text { office }\end{array}$ & $\begin{array}{l}\text { ND } \\
\text { WD }\end{array}$ & $\frac{28 \%}{16 \%}$ & \begin{tabular}{|l}
$43 \%$ \\
$69 \%$ \\
\end{tabular} & $\begin{array}{c}30 \% \\
15 \%\end{array}$ \\
\hline
\end{tabular}




\section{SECTION 12- SOCIAL LIFE}

Table 27

Participants responses: How often do the following social activities occur on campus?

\begin{tabular}{|c|c|c|c|c|c|c|c|c|c|c|c|c|}
\hline & \multicolumn{4}{|c|}{ Frequently } & \multicolumn{4}{|c|}{ Occasionally } & \multicolumn{4}{|c|}{ Never } \\
\hline & \multicolumn{2}{|c|}{ No Disability } & \multicolumn{2}{|c|}{ WD } & \multicolumn{2}{|c|}{ ND } & \multicolumn{2}{|c|}{ WD } & \multicolumn{2}{|c|}{ ND } & \multicolumn{2}{|c|}{ WD } \\
\hline & $n$ & $\%$ & $n$ & $\%$ & $n$ & $\%$ & $n$ & $\%$ & $n$ & $\%$ & $n$ & $\%$ \\
\hline $\begin{array}{l}\text { Organized } \\
\text { university-wide } \\
\text { social activities }\end{array}$ & 5,583 & 13.49 & 349 & 15.45 & 21,656 & 52.35 & 1,153 & 51.04 & 14,132 & 34.16 & 757 & 33.51 \\
\hline $\begin{array}{l}\text { Organized social } \\
\text { activities within } \\
\text { your department }\end{array}$ & 4,369 & 10.53 & 242 & 10.69 & 25,861 & 62.36 & 1,473 & 65.06 & 11,243 & 27.11 & 549 & 24.25 \\
\hline $\begin{array}{l}\text { Organized social } \\
\text { activities within } \\
\text { your } \\
\text { advisor/research } \\
\text { group }\end{array}$ & 15,114 & 36.98 & 1,015 & 45.39 & 20,027 & 49.00 & 953 & 42.62 & 5,732 & 14.02 & 268 & 11.99 \\
\hline $\begin{array}{l}\text { Organized social } \\
\text { activities within } \\
\text { your residence }\end{array}$ & 24,236 & 64.77 & 1,514 & 74.11 & 9,827 & 26.26 & 393 & 19.24 & 3,353 & 8.96 & 136 & 6.66 \\
\hline
\end{tabular}

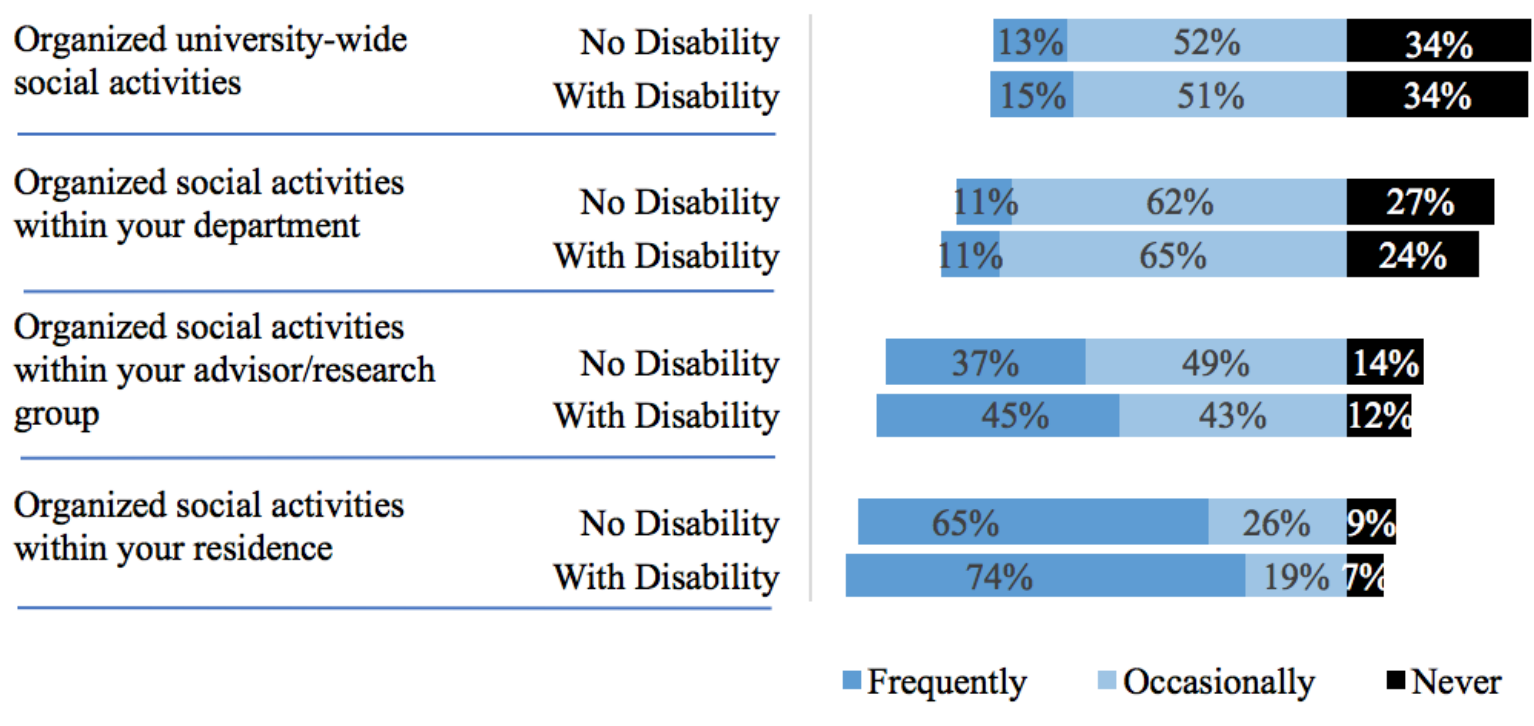


Table 28

Participants responses: How often do you attend these social events?

\begin{tabular}{|c|c|c|c|c|c|c|c|c|c|c|c|c|}
\hline & \multicolumn{4}{|c|}{ Frequently } & \multicolumn{4}{|c|}{ Occasionally } & \multicolumn{4}{|c|}{ Never } \\
\hline & \multicolumn{2}{|c|}{ No Disability } & \multicolumn{2}{|c|}{$\begin{array}{c}\text { With a } \\
\text { Disability }\end{array}$} & \multicolumn{2}{|c|}{ No Disability } & \multicolumn{2}{|c|}{$\begin{array}{c}\text { With a } \\
\text { Disability }\end{array}$} & \multicolumn{2}{|c|}{ No Disability } & \multicolumn{2}{|c|}{$\begin{array}{c}\text { With a } \\
\text { Disability }\end{array}$} \\
\hline & $n$ & $\%$ & $n$ & $\%$ & $n$ & $\%$ & $n$ & $\%$ & $n$ & $\%$ & $n$ & $\%$ \\
\hline $\begin{array}{l}\text { Organized } \\
\text { university-wide } \\
\text { social activities }\end{array}$ & 17,771 & 52.29 & 1,114 & 60.54 & 14,736 & 43.36 & 659 & 35.82 & 1,479 & 4.35 & 67 & 3.64 \\
\hline $\begin{array}{l}\text { Organized social } \\
\text { activities within } \\
\text { your department }\end{array}$ & 7,298 & 20.96 & 358 & 18.74 & 20,065 & 57.63 & 1,144 & 59.90 & 7,454 & 21.41 & 408 & 21.36 \\
\hline $\begin{array}{l}\text { Organized social } \\
\text { activities within } \\
\text { your } \\
\text { advisor/research } \\
\text { group }\end{array}$ & 3,770 & 15.86 & 189 & 16.61 & 10,227 & 43.02 & 506 & 44.46 & 9,773 & 41.11 & 443 & 38.93 \\
\hline $\begin{array}{l}\text { Organized social } \\
\text { activities within } \\
\text { your residence }\end{array}$ & 5,184 & 43.52 & 266 & 53.63 & 4,711 & 39.55 & 160 & 32.26 & 2,017 & 16.93 & 70 & 14.11 \\
\hline
\end{tabular}

\begin{tabular}{lr}
$\begin{array}{l}\text { Organized university-wide } \\
\text { social activities }\end{array}$ & $\begin{array}{r}\text { No Disability } \\
\text { With Disability }\end{array}$ \\
\hline $\begin{array}{l}\text { Organized social activities } \\
\text { within your department }\end{array}$ & $\begin{array}{r}\text { No Disability } \\
\text { With Disability }\end{array}$ \\
\hline $\begin{array}{l}\text { Organized social activities } \\
\text { within your advisor/research } \\
\text { group }\end{array}$ & $\begin{array}{r}\text { No Disability } \\
\text { With Disability }\end{array}$ \\
\hline $\begin{array}{l}\text { Organized social activities } \\
\text { within your residence }\end{array}$ & No Disability \\
& With Disability \\
\hline
\end{tabular}
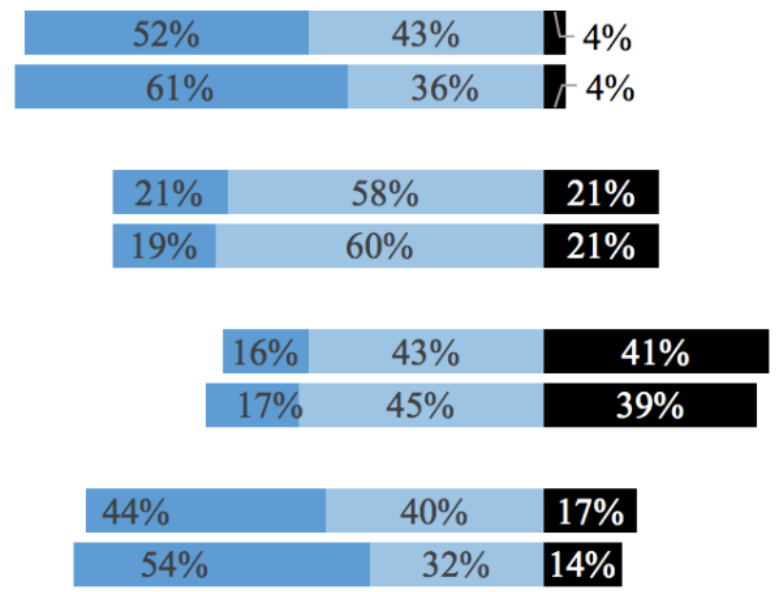

Erequently $\quad$ Occasionally $\quad$ Never 
Table 29

Participants responses: In the current academic year, have you been physically present on campus (or affiliated institute) on a regular basis, or have you been away most of the time (out of town, out of the country, field work, distance program, working at a separate location, etc.)?

\begin{tabular}{lcccc}
\hline & \multicolumn{2}{c}{$\begin{array}{c}\text { Students without } \\
\text { Disabilities }\end{array}$} & \multicolumn{2}{c}{$\begin{array}{c}\text { Students with } \\
\text { Disabilities }\end{array}$} \\
\cline { 2 - 5 } & $n$ & $\%$ & $n$ & $\%$ \\
\hline Physically present & 33,241 & 78.73 & 1,747 & 76.46 \\
Away most of the time & 8,978 & 21.27 & 538 & 23.54 \\
\hline
\end{tabular}




\section{SECTION 13- GENERAL ASSESSMENT}

Table 30

Participants' responses: Overall, how would you rate the quality of:

\begin{tabular}{|c|c|c|c|c|c|c|c|c|c|c|}
\hline & \multicolumn{2}{|c|}{ Excellent } & \multicolumn{2}{|c|}{ Very good } & \multicolumn{2}{|c|}{ Good } & \multicolumn{2}{|c|}{ Fair } & \multicolumn{2}{|c|}{ Poor } \\
\hline & $\begin{array}{c}\text { No } \\
\text { Disability }^{\mathrm{a}}\end{array}$ & $\begin{array}{c}\text { With a } \\
\text { Disability }^{\mathrm{b}}\end{array}$ & ND & WD & ND & WD & ND & WD & ND & WD \\
\hline $\begin{array}{l}\text { Your academic } \\
\text { experience at this } \\
\text { university? }\end{array}$ & 27.97 & 22.91 & 40.19 & 36.24 & 22.12 & 24.38 & 7.16 & 11.13 & 2.55 & 5.33 \\
\hline $\begin{array}{l}\text { Your student life } \\
\text { experience at this } \\
\text { university? }\end{array}$ & 17.23 & 12.44 & 31.25 & 24.88 & 31.20 & 31.10 & 14.62 & 19.65 & 5.70 & 11.92 \\
\hline $\begin{array}{l}\text { Your graduate/ } \\
\text { professional } \\
\text { program at this } \\
\text { university? }\end{array}$ & 25.44 & 20.55 & 36.53 & 32.36 & 24.07 & 24.82 & 9.98 & 13.79 & 3.97 & 8.49 \\
\hline $\begin{array}{l}\text { Your overall } \\
\text { experience at this } \\
\text { university? }\end{array}$ & 22.78 & 16.71 & 39.00 & 32.47 & 26.20 & 29.24 & 9.32 & 14.81 & 2.70 & 6.76 \\
\hline
\end{tabular}

Note. Values represent percentages of respondents.

$\mathrm{N}^{\mathrm{a}}=42,353-42,809 . \mathrm{N}^{\mathrm{b}}=2,315-2,326$.

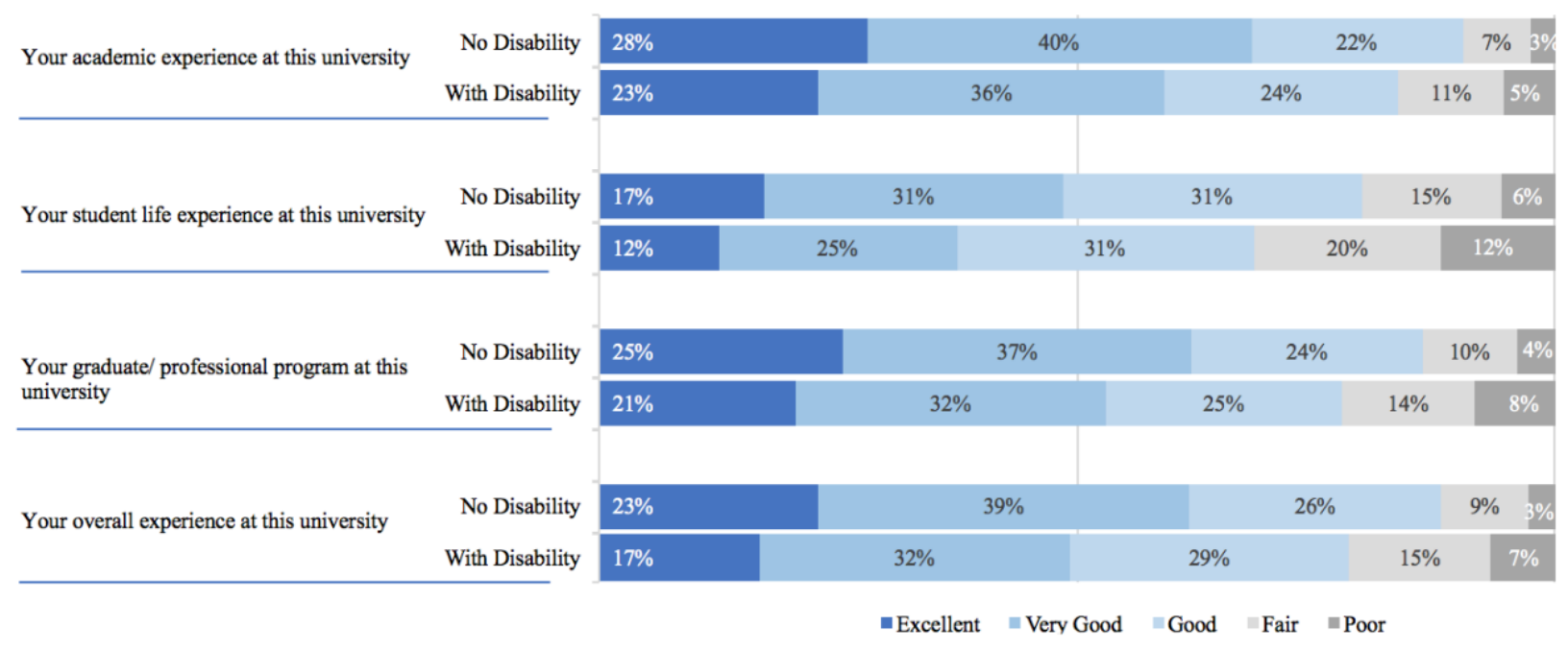


Table 31

Participants responses: Rate the extent to which the following factors are an obstacle to your academic progress.

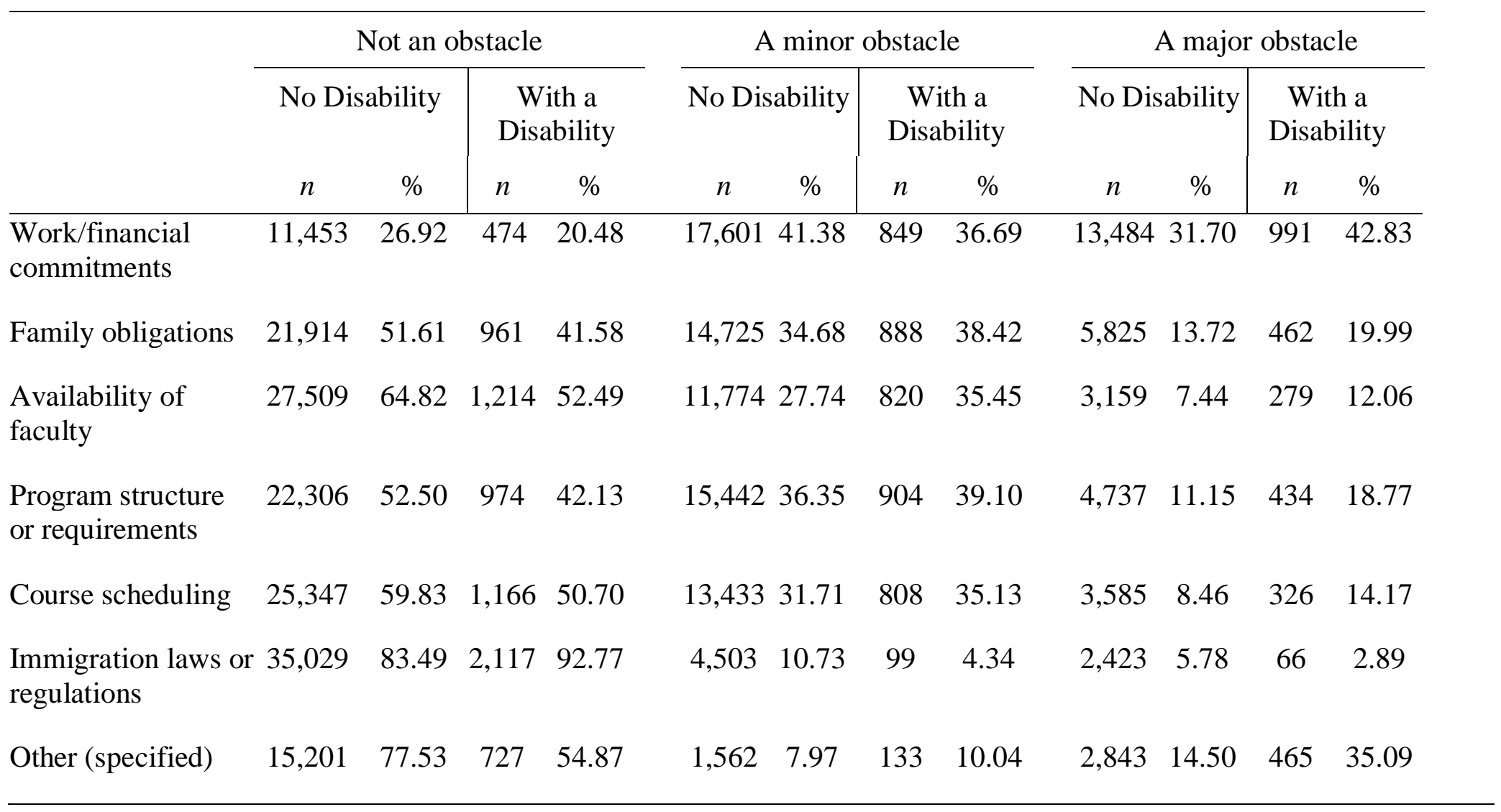




\begin{tabular}{lr} 
Work/financial commitments & $\begin{array}{r}\text { No Disability } \\
\text { With Disability }\end{array}$ \\
\hline Family obligations & $\begin{array}{r}\text { No Disability } \\
\text { With Disability }\end{array}$ \\
Availability of faculty & No Disability \\
\hline $\begin{array}{l}\text { Program structure or } \\
\text { requirements }\end{array}$ & No Disability \\
\hline $\begin{array}{l}\text { Course scheduling } \\
\text { With Disability }\end{array}$ \\
$\begin{array}{l}\text { Immigration laws or } \\
\text { regulations }\end{array}$ \\
$\begin{aligned} \text { No Disability } \\
\text { Other (specified) }\end{aligned}$ \\
\hline $\begin{array}{l}\text { With Disability } \\
\text { No Disability }\end{array}$
\end{tabular}

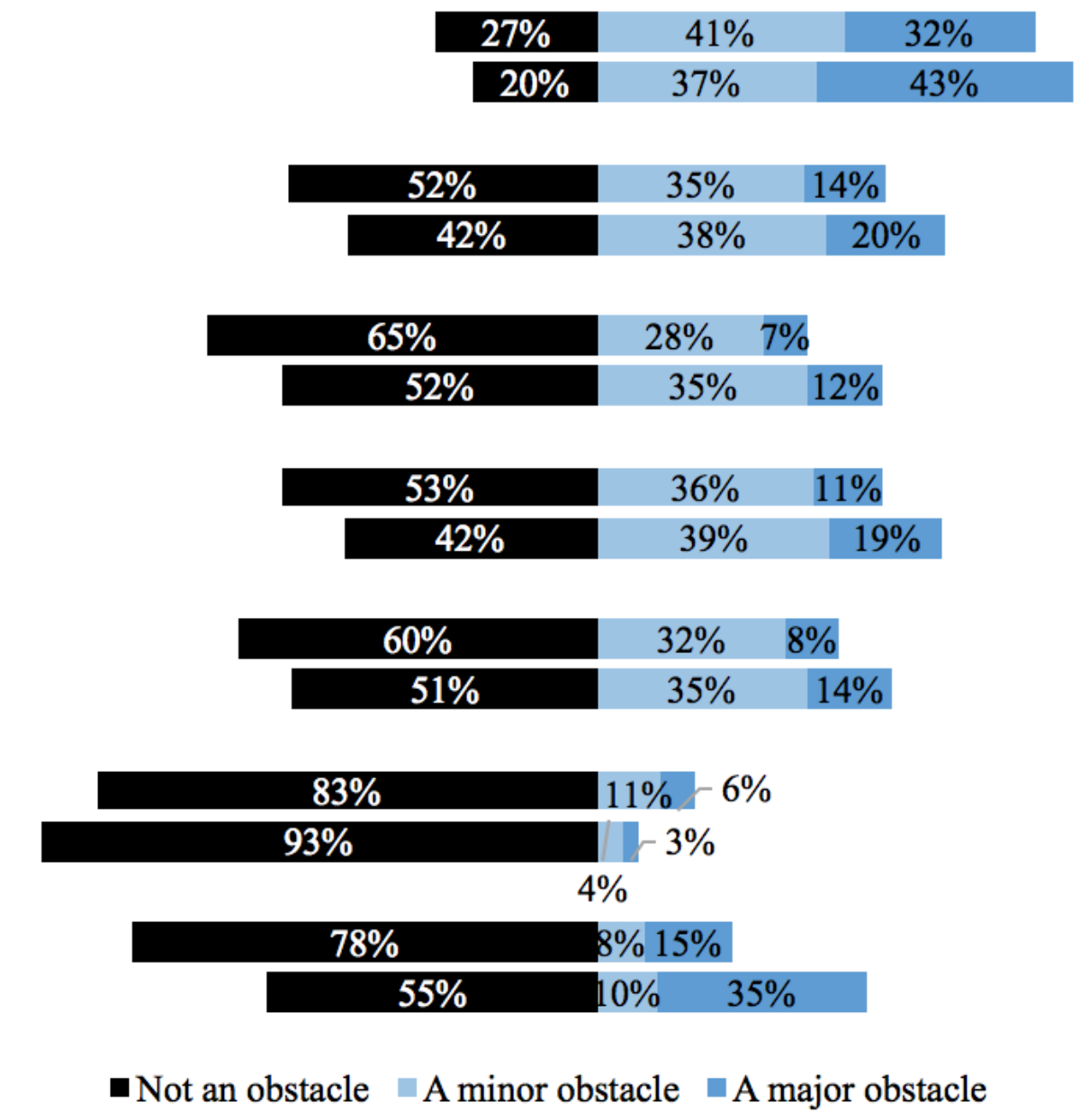


Table 32

Participants' responses: As it relates to your current program, how important is it to have the opportunity to ...

\begin{tabular}{|c|c|c|c|c|c|c|c|c|}
\hline & \multicolumn{2}{|c|}{ Very important } & \multicolumn{2}{|c|}{$\begin{array}{l}\text { Somewhat } \\
\text { important }\end{array}$} & \multicolumn{2}{|c|}{ Not important } & \multicolumn{2}{|c|}{ Not applicable } \\
\hline & $\begin{array}{c}\text { No } \\
\text { Disability }^{\mathrm{a}}\end{array}$ & $\begin{array}{c}\text { With a } \\
\text { Disability }\end{array}$ & ND & WD & ND & WD & ND & WD \\
\hline Study abroad & 25.91 & 18.92 & 26.78 & 27.26 & 34.50 & 41.12 & 12.80 & 12.70 \\
\hline $\begin{array}{l}\text { Collaborate on } \\
\text { research } \\
\text { internationally }\end{array}$ & 38.45 & 31.36 & 30.57 & 36.90 & 20.99 & 22.04 & 10.10 & 9.70 \\
\hline $\begin{array}{l}\text { Network with not } \\
\text { for profit } \\
\text { organizations }\end{array}$ & 30.69 & 34.49 & 32.97 & 33.01 & 25.17 & 23.63 & 11.17 & 8.86 \\
\hline $\begin{array}{l}\text { Work/collaborate } \\
\text { with businesses }\end{array}$ & 39.63 & 29.36 & 27.92 & 31.97 & 22.63 & 29.53 & 9.82 & 9.15 \\
\hline $\begin{array}{l}\text { Network with } \\
\text { local/ provincial/ } \\
\text { federal } \\
\text { government }\end{array}$ & 42.98 & 43.67 & 32.89 & 33.35 & 15.81 & 15.83 & 8.33 & 7.16 \\
\hline
\end{tabular}

Note. Values represent percentages of respondents.

$\mathrm{N}^{\mathrm{a}}=42.315-42,524 . \mathrm{N}^{\mathrm{b}}=2,296-2,315$.

\begin{tabular}{|c|c|c|c|c|c|}
\hline & & Very Important & $\begin{array}{l}\text { Somewhat } \\
\text { Important }\end{array}$ & Not Important & $\begin{array}{c}\text { Not } \\
\text { Applicable }\end{array}$ \\
\hline \multirow[b]{2}{*}{ Study abroad } & No Disability & $26 \%$ & $27 \%$ & $35 \%$ & $13 \%$ \\
\hline & With Disability & $19 \%$ & $27 \%$ & $41 \%$ & $13 \%$ \\
\hline \multirow{2}{*}{ Collaborate on research internationally } & No Disability & $38 \%$ & $31 \%$ & $21 \%$ & $10 \%$ \\
\hline & With Disability & $31 \%$ & $37 \%$ & $22 \%$ & $10 \%$ \\
\hline \multirow{2}{*}{ Network with not for profit organizations } & No Disability & $31 \%$ & $33 \%$ & $25 \%$ & $11 \%$ \\
\hline & With Disability & $34 \%$ & $33 \%$ & $24 \%$ & $9 \%$ \\
\hline \multirow{2}{*}{ Work/collaborate with businesses } & No Disability & $40 \%$ & $28 \%$ & $23 \%$ & $10 \%$ \\
\hline & With Disability & $29 \%$ & $32 \%$ & $30 \%$ & $9 \%$ \\
\hline \multirow{2}{*}{$\begin{array}{l}\text { Network with local/ provincial/ federal } \\
\text { government }\end{array}$} & No Disability & $43 \%$ & $33 \%$ & $16 \%$ & $8 \%$ \\
\hline & With Disability & $44 \%$ & $33 \%$ & $16 \%$ & $7 \%$ \\
\hline
\end{tabular}


Table 33

Participants' responses: As it relates to your current program, have opportunities been available to...

\begin{tabular}{|c|c|c|c|c|c|c|c|c|}
\hline & \multicolumn{2}{|c|}{ Yes, to a great extent } & \multicolumn{2}{|c|}{$\begin{array}{l}\text { Yes, to some } \\
\text { extent }\end{array}$} & \multicolumn{2}{|c|}{$\begin{array}{c}\text { No } \\
\text { opportunity }\end{array}$} & \multicolumn{2}{|c|}{ Not applicable } \\
\hline & $\begin{array}{c}\text { No } \\
\text { Disability }^{\mathrm{a}}\end{array}$ & $\begin{array}{c}\text { With a } \\
\text { Disability }\end{array}$ & ND & WD & ND & WD & ND & WD \\
\hline Study abroad & 11.20 & 7.58 & 32.79 & 33.22 & 38.51 & 41.63 & 17.51 & 17.57 \\
\hline $\begin{array}{l}\text { Collaborate on } \\
\text { research } \\
\text { internationally }\end{array}$ & 11.11 & 7.16 & 32.05 & 30.96 & 42.15 & 47.83 & 14.70 & 14.05 \\
\hline $\begin{array}{l}\text { Network with not for } \\
\text { profit organizations }\end{array}$ & 8.37 & 8.48 & 30.93 & 33.44 & 44.38 & 44.07 & 16.32 & 14.02 \\
\hline $\begin{array}{l}\text { Work/collaborate } \\
\text { with businesses }\end{array}$ & 10.08 & 6.10 & 30.32 & 27.26 & 44.30 & 50.53 & 15.29 & 16.11 \\
\hline $\begin{array}{l}\text { Work/collaborate } \\
\text { with local/ provincial/ } \\
\text { federal government }\end{array}$ & 9.12 & 7.48 & 30.66 & 28.41 & 46.21 & 50.66 & 14.01 & 13.46 \\
\hline
\end{tabular}

Note. Values represent percentages of respondents.

$\mathrm{N}^{\mathrm{a}}=41,702-41,903 . \mathrm{N}^{\mathrm{b}}=2,274-2,282$.

\begin{tabular}{|c|c|c|c|c|c|}
\hline \multirow{3}{*}{ Study abroad } & & $\begin{array}{l}\text { Yes, to } \\
\text { a great } \\
\text { extent }\end{array}$ & $\begin{array}{l}\text { Yes, to some } \\
\text { extent }\end{array}$ & No opportunity & $\begin{array}{c}\text { Not } \\
\text { Applicable }\end{array}$ \\
\hline & No Disability & $11 \%$ & $33 \%$ & $39 \%$ & $18 \%$ \\
\hline & With Disability & $8 \%$ & $33 \%$ & $42 \%$ & $18 \%$ \\
\hline \multirow{2}{*}{ Collaborate on research internationally } & No Disability & $11 \%$ & $32 \%$ & $42 \%$ & $15 \%$ \\
\hline & With Disability & $7 \%$ & $31 \%$ & $48 \%$ & $14 \%$ \\
\hline \multirow{2}{*}{ Network with not for profit organizations } & No Disability & $8 \%$ & $31 \%$ & $44 \%$ & $16 \%$ \\
\hline & With Disability & $8 \%$ & $33 \%$ & $44 \%$ & $14 \%$ \\
\hline \multirow[t]{2}{*}{ Work/collaborate with businesses } & No Disability & $10 \%$ & $30 \%$ & $44 \%$ & $15 \%$ \\
\hline & With Disability & & $6 \% 27 \%$ & $51 \%$ & $16 \%$ \\
\hline \multirow{2}{*}{$\begin{array}{l}\text { Network with local/ provincial/ federal } \\
\text { government }\end{array}$} & No Disability & $9 \%$ & $31 \%$ & $46 \%$ & $14 \%$ \\
\hline & With Disability & $7 \%$ & $28 \%$ & $51 \%$ & $13 \%$ \\
\hline
\end{tabular}

